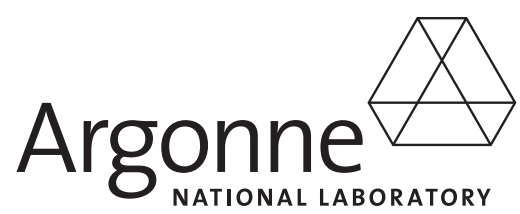

ANL/EVS/AGEM/TR-08-08

\title{
March 2008 Monitoring Results for Centralia, Kansas
}

\section{Environmental Science Division}




\begin{abstract}
About Argonne National Laboratory
Argonne is a U.S. Department of Energy laboratory managed by UChicago Argonne, LLC under contract DE-AC02-06CH11357. The Laboratory's main facility is outside Chicago, at 9700 South Cass Avenue, Argonne, Illinois 60439. For information about Argonne, see www.anl.gov.
\end{abstract}

\title{
Availability of This Report
}

This report is available, at no cost, at http://www.osti.gov/bridge. It is also available on paper to the U.S. Department of Energy and its contractors, for a processing fee, from:

U.S. Department of Energy

Office of Scientific and Technical Information

P.O. Box 62

Oak Ridge, TN 37831-0062

phone (865) 576-8401

fax (865) 576-5728

reports@adonis.osti.gov

\section{Disclaimer}

This report was prepared as an account of work sponsored by an agency of the United States Government. Reference herein to any specific commercial product, process, or service by trade name, trademark, manufacturer, or otherwise, does not necessarily constitute or imply its endorsement, recommendation, or favoring by the United States Government or any agency thereof. The views and opinions of document authors expressed herein do not necessarily state or reflect those of the United States Government or any agency thereof, Argonne National Laboratory, or UChicago Argonne, LLC. 


\section{March 2008 Monitoring Results for Centralia, Kansas}

by

Applied Geosciences and Environmental Management Section

Environmental Science Division, Argonne National Laboratory

May 2008

USDA 


\section{Contents}

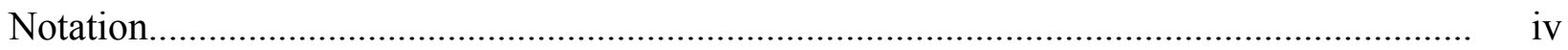

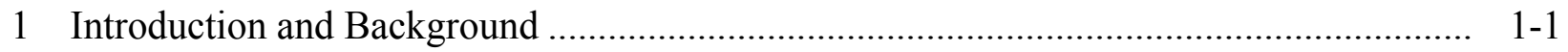

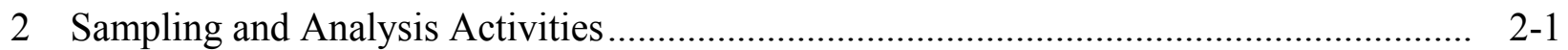

2.1 Measurement of Groundwater Levels.............................................................. 2-1

2.2 Monitoring Well and Piezometer Sampling and Analyses ...................................... 2- 2-1

2.3 Handling and Disposal of Investigation-Derived Waste .......................................... 2-2

2.4 Quality Control for Sample Collection, Handling, and Analysis ........................... 2-2

3 Results and Discussion ...................................................................................... $3-1$

3.1 Groundwater Level Data............................................................................ 3-1

3.2 Groundwater Analysis Results............................................................................ 3-1

3.2.1 Results of the Groundwater Analyses for VOCs ........................................ 3-1

3.2.2 Results of Other Groundwater Analyses.................................................. 3-2

4 Conclusions and Recommendations ......................................................................... 4-1

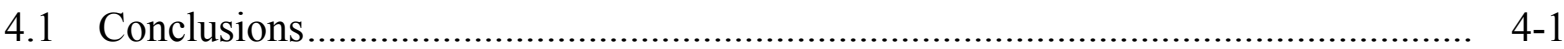

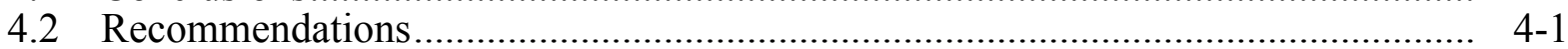

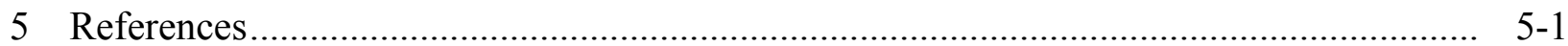

Appendix A: Low-Flow Sampling Procedure EPA/540/S-95/504....................................... A-1

Appendix B: Sequence of Sampling Activities at Centralia, Kansas, in March 2008 ............ B-1

Appendix C: Data Summary for Verification VOCs analyses by Envirosystems, Inc. .......... C-1

\section{Tables}

3.1 Groundwater levels measured by hand at Centralia in November 2007 and March 2008

3.2 Analytical results from the AGEM Laboratory for volatile organic compounds in groundwater samples collected at Centralia, August 2004 to March 2008 
3.3 Field measurements for groundwater samples collected at Centralia, August 2004 to March 2008

B.1 Sequence of sampling activities at Centralia in March 2008

\section{Figures}

1.1 Approved monitoring network at Centralia

3.1 Potentiometric surface at Centralia, based on water levels measured manually on November 12, 2007

3.2 Carbon tetrachloride levels in groundwater at Centralia in March 2008, with the interpreted lateral extent of the contaminant at intervals during the period August 2004 to March 2008 


\section{Notation}

AGEM Applied Geosciences and Environmental Management

AMSL above mean sea level

BGL below ground level

${ }^{\circ} \mathrm{C} \quad$ degree(s) Celsius

CCC Commodity Credit Corporation

COC chain of custody

EDB ethylene dibromide

EPA U.S. Environmental Protection Agency

$\mathrm{ft} \quad$ foot (feet)

in. inch(es)

ISCR in situ chemical reduction

KDHE Kansas Department of Health and Environment

L liter(s)

$\mu \mathrm{g} / \mathrm{L} \quad$ microgram(s) per liter

$\mu \mathrm{S} / \mathrm{cm} \quad$ microsiemen(s) per centimeter

$\mathrm{mg} / \mathrm{L} \quad$ milligram(s) per liter

$\mathrm{mV} \quad$ millivolt(s)

NAD North American Datum

NGVD National Geodetic Vertical Datum

ORP oxidation-reduction potential

TOC top of casing

USDA U.S. Department of Agriculture

VOC volatile organic compound 


\section{March 2008 Monitoring Results for Centralia, Kansas}

\section{Introduction and Background}

In September 2005, periodic sampling of groundwater was initiated by the Commodity Credit Corporation of the U.S. Department of Agriculture (CCC/USDA) in the vicinity of a grain storage facility formerly operated by the CCC/USDA at Centralia, Kansas. The sampling at Centralia is being performed on behalf of the CCC/USDA by Argonne National Laboratory, in accord with a monitoring program approved by the Kansas Department of Health and Environment (KDHE). The objective is to monitor levels of carbon tetrachloride contamination identified in the groundwater at Centralia (Argonne 2003, 2004, 2005a). Under the KDHEapproved monitoring plan (Argonne 2005b), the groundwater is being sampled twice yearly (for a recommended period of two years) for analyses for volatile organic compounds (VOCs), as well as measurement of selected geochemical parameters to aid in the evaluation of possible natural contaminant degradation (reductive dechlorination) processes in the subsurface environment. The sampling is presently conducted in a network of 10 monitoring wells and 6 piezometers (Figure 1.1), at locations approved by the KDHE (Argonne 2006a).

The results of groundwater sampling and VOCs analyses in September-October 2005, March 2006, September 2006, March 2007, and September 2007 were documented previously (Argonne 2006a,b, 2007a, 2008). The results have demonstrated the presence of carbon tetrachloride contamination, at levels exceeding the KDHE Tier 2 Risk-Based Screening Level of $5 \mu \mathrm{g} / \mathrm{L}$ for this compound, in a broad groundwater plume that has shown little movement.

This report presents the results of the groundwater sampling at Centralia in March 2008, performed in accord with the KDHE-approved monitoring plan (Argonne 2005b). The September 2007 sampling represented the fifth and final monitoring event performed under the recommended two-year monitoring program approved by the KDHE. The March 2008 sampling begins an extension of the approved monitoring that is to continue until the final site remedy has been implemented and a comprehensive program of performance and compliance monitoring has been established at Centralia (KDHE 2008a). 


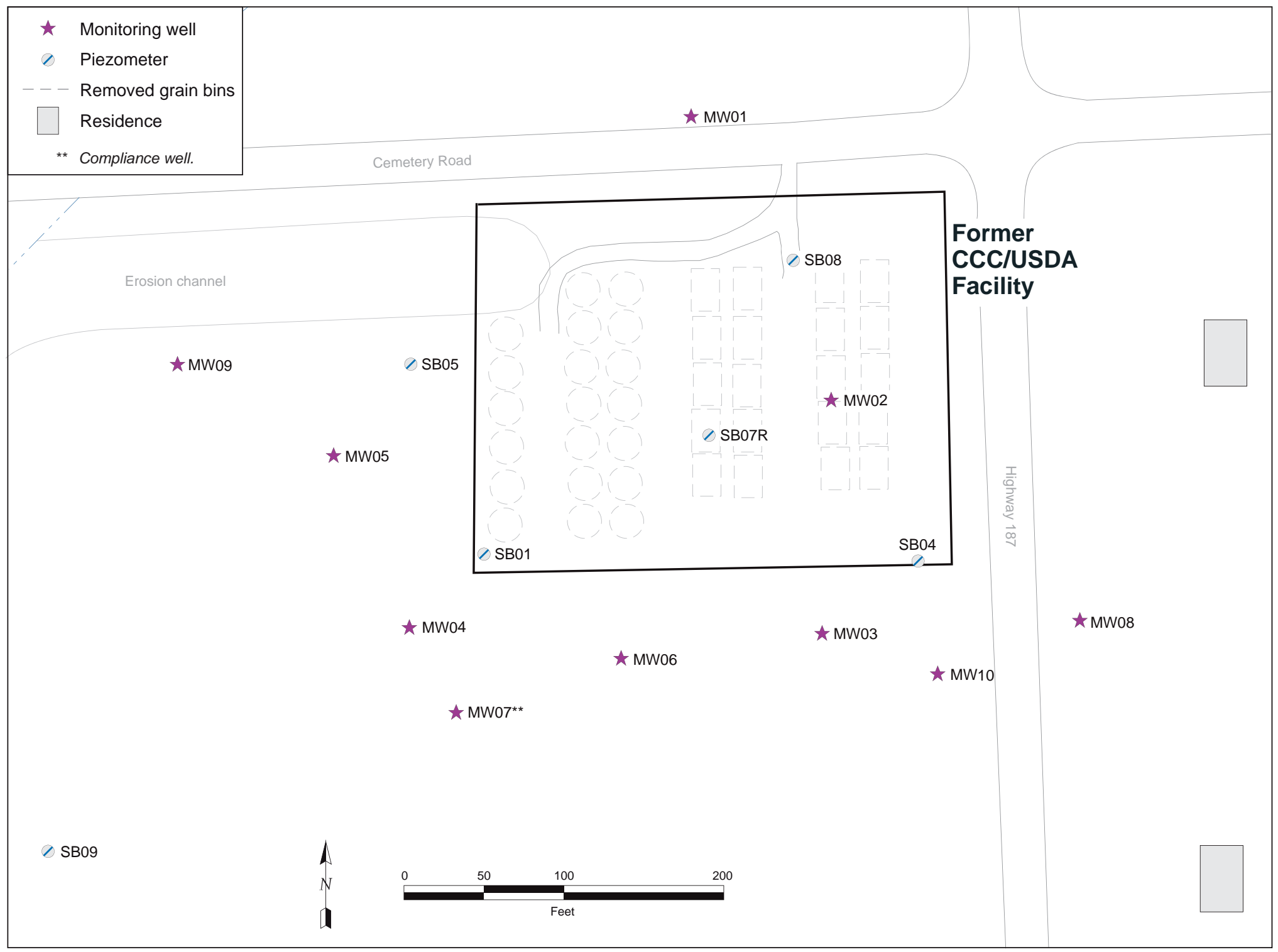

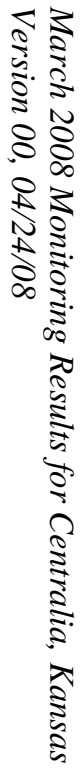

FIGURE 1.1 Approved monitoring network at Centralia. 


\section{Sampling and Analysis Activities}

\subsection{Measurement of Groundwater Levels}

Monitoring wells MW01-MW10 and piezometers SB01, SB04, SB05, SB07R, SB08, and SB09 (Figure 1.1) were sampled on March 12-20, 2008. Before the sampling, a water level indicator was used to measure the depth to groundwater and the total depth of each well, to within $0.01 \mathrm{ft}$, from the top of the well casing. Samples were collected by using a low-flow bladder pump and a Waterra pump, with the approval of the KDHE (2008b).

Data recorders currently installed in MW01-MW06 are gathering long-term data on the groundwater elevation and gradient at Centralia. The data recorders in these wells were downloaded, and water levels were measured manually at all monitoring points, on November 12, 2007.

The groundwater level data are discussed in Section 3.1.

\subsection{Monitoring Well and Piezometer Sampling and Analyses}

After measurement of water levels and dissolved oxygen levels, each monitoring point was purged of a small volume. Field measurements of temperature, $\mathrm{pH}$, and conductivity were taken during purging until the measurements stabilized. Field measurements of iron(II) and oxidation reduction potential (ORP) were made as outlined in the monitoring plan (Argonne 2005b). Low-flow sampling was according to U.S. Environmental Protection Agency (EPA) procedure EPA/540/S-95/504 (Puls and Barcelona 1996; Appendix A in the present document) and the equipment manufacturers' instructions. All field analyses were performed in accord with procedures in the Master Work Plan (Argonne 2002). The sequence of activities during the March 2008 well sampling event is summarized in Appendix B.

Groundwater samples designated for VOCs analyses and selected geochemical analyses identified in the monitoring plan (Argonne 2005b) were collected in appropriate laboratory containers, labeled, packaged, and chilled to $4^{\circ} \mathrm{C}$ by placement in ice-filled coolers. The samples were shipped by an overnight delivery service to the Applied Geosciences and Environmental Management (AGEM) Laboratory at Argonne for VOCs analyses with U.S. Environmental 
Protection Agency (EPA) Method 524.2 (EPA 1995). Aliquots of selected samples (chosen in the field) were also shipped to Envirosystems, Inc., Columbia, Maryland, for verification VOCs analyses.

The analytical results for groundwater samples are discussed in Section 3.2.

\subsection{Handling and Disposal of Investigation-Derived Waste}

Purge water generated as potentially contaminated investigation-derived waste was containerized on-site. The accumulated purge water was sampled and analyzed by Pace Analytical Services, Inc., Lenexa, Kansas. Methods used were EPA Method 5030/8260 for VOCs, EPA Method 504.1 for ethylene dibromide (EDB), and EPA Method 300 for nitrate as nitrogen. Carbon tetrachloride was detected at $6.6 \mu \mathrm{g} / \mathrm{L}$, and chloroform was detected at $20 \mu \mathrm{g} / \mathrm{L}$, but EDB was not detected. Nitrate was present at $1.2 \mathrm{mg} / \mathrm{L}$. With the approval of the KDHE (2008c), the water is being disposed of at the Sabetha, Kansas, publicly owned treatment works during the week of May 19-23, 2008.

\subsection{Quality Control for Sample Collection, Handling, and Analysis}

Quality assurance/quality control procedures followed during the March 2008 monitoring event are described in detail in the Master Work Plan (Argonne 2002). The results are summarized as follows:

- Sample collection and handling activities were monitored by the documentation of samples as they were collected and the use of chain-ofcustody forms and custody seals to ensure sample integrity during handling and shipment.

- Samples designated for VOCs analyses were received with custody seals intact and at the appropriate preservation temperature. All samples were analyzed within the required holding times.

- Quality control samples collected to monitor sample collection and handling activities included equipment rinsates and trip blanks. In addition, method 
blanks were analyzed with the samples to monitor analytical methodologies. All quality control samples analyzed at the AGEM Laboratory were free of carbon tetrachloride and chloroform contamination.

- Groundwater samples were analyzed for VOCs at the AGEM Laboratory with the purge-and-trap method on a gas chromatograph-mass spectrometer system. Calibration checks with each sample delivery group were required to be within $\pm 20 \%$ of the standard. Surrogate standard determinations performed on samples and blanks were within the specified range of $80-120 \%$ for all samples, in either the initial analysis or a successful reanalysis.

- In accordance with the procedures defined in the Master Work Plan (Argonne 2002), the analyses of water samples at the AGEM Laboratory were verified by a second laboratory. Three groundwater samples collected during the March 2008 monitoring event - from monitoring wells MW03, MW04, and MW06 - were submitted to Envirosystems, Inc., for analysis according to the EPA's Contract Laboratory Program methodology. In the AGEM Laboratory analysis with the purge-and-trap method (quantitation limit $1.0 \mu \mathrm{g} / \mathrm{L}$ ), low concentrations of carbon tetrachloride were detected in the samples from MW03 $(2.3 \mu \mathrm{g} / \mathrm{L})$ and MW04 $(1.3 \mu \mathrm{g} / \mathrm{L})$. The contaminant was not detected in these two samples by Envirosystems, Inc., in its analysis with the higher quantitation limit of $5.0 \mu \mathrm{g} / \mathrm{L}$. Carbon tetrachloride was not detected in the sample from MW06 by either laboratory. Chloroform was not detected in any of the three samples by either laboratory. Methylene chloride was detected in all samples analyzed by Envirosystems, Inc., including the associated laboratory blanks, but it was not detected in analyses by the AGEM Laboratory. Likewise, trace detections of toluene by Envirosystems, Inc., are attributed to laboratory contamination. Summary pages for the verification organic analyses are in Appendix C. 


\section{Results and Discussion}

\subsection{Groundwater Level Data}

Depths to groundwater were measured manually in all available monitoring wells on November 12, 2007, and March 12-20, 2008 (during sampling). The hand-measured water level data are in Table 3.1. The tables for Section 3 are grouped at the end of the section's text, before the figures.

The potentiometric surface at Centralia, interpreted from manual measurements on November 12, 2007, is depicted in Figure 3.1. The recent results are consistent with previous measurements (Argonne 2006a, 2007a, 2008), indicating an apparent groundwater flow direction toward the southwest across much of the former CCC/USDA facility. Like previous depictions of the potentiometric surface, Figure 3.1 indicates that groundwater flow is focused toward a localized low in the potentiometric surface, defined by the water level measurements at SB01, MW04, MW06, and MW07. Argonne's earlier investigations (Argonne 2003, 2004) suggested that the increased hydraulic gradients observed near these wells are a reflection of relatively lowpermeability silts and clays that comprise the aquifer unit in this portion of the study area, in comparison to the more coarse-grained deposits identified in the northern and eastern portions of the site. The results of groundwater analyses at Centralia (discussed in Section 3.2) support an interpretation of slow groundwater flow (and carbon tetrachloride migration) to the southsouthwest, in keeping with the observed water level patterns.

\subsection{Groundwater Analysis Results}

\subsubsection{Results of the Groundwater Analyses for VOCs}

The analytical data for VOCs in the groundwater samples collected in March 2008 are in Table 3.2, together with data for the previous sampling events conducted at Centralia since sampling of the monitoring well network began in 2004. The March 2008 data for carbon tetrachloride are illustrated in Figure 3.2, along with the lateral margins of the plume, as interpreted by Argonne on the basis of each of the groundwater sampling events summarized in Table 3.2. 
Carbon tetrachloride was detected in March 2008 at 9 of the 16 designated monitoring locations (Argonne 2005b) on and downgradient from the former CCC/USDA facility (Figure 3.2), at concentrations ranging from $1.3 \mu \mathrm{g} / \mathrm{L}$ (at MW04) to a maximum of $325 \mu \mathrm{g} / \mathrm{L}$ (at SB01). Chloroform concentrations ranging from $<1 \mu \mathrm{g} / \mathrm{L}$ to $17 \mu \mathrm{g} / \mathrm{L}$ were detected at 6 of the 16 sampled locations (Table 3.2), typically in association with the more elevated carbon tetrachloride concentrations identified beneath the former CCC/USDA facility (at SB01, SB04, SB07R, and SB08) and immediately to the west (at SB05). The decrease in carbon tetrachloride concentrations noted at MW02 (from 1,138 $\mathrm{g} / \mathrm{L}$ in September 2007 to not detected in March 2008) is related to the Interim Measure pilot test (Argonne 2007b) initiated in December 2007. The results of the pilot test will be reported separately.

Except for the noted change at MW02, the present carbon tetrachloride concentrations are consistent with previous measurements. The data in Table 3.2 and Figure 3.2 continue to suggest longer-term trends of increasing carbon tetrachloride levels at monitoring points SB05, MW03, and MW07, along the western and southern margins of the groundwater plume and in the apparent direction of groundwater flow.

\subsubsection{Results of Other Groundwater Analyses}

The results of field measurements on the groundwater samples are summarized in Table 3.3. Additional parameters were formerly reported to estimate whether the in situ conditions at Centralia are suitable for possible degradation of carbon tetrachloride by natural anaerobic (reductive dechlorination) processes, as outlined in regulatory guidance for the evaluation of these conditions (KDHE 2001; EPA 1998). Because the results gave only limited evidence for possible anaerobic biodegradation of carbon tetrachloride at Centralia, the analyses for additional parameters have been discontinued. The persistent occurrence of the carbon tetrachloride breakdown product chloroform at relatively elevated concentrations at monitoring points SB01, SB05, and MW02 during the March 2005 sampling event and subsequently (Table 3.2) suggested that carbon tetrachloride degradation was occurring at these locations. 
TABLE 3.1 Groundwater levels measured by hand at Centralia in November 2007 and March 2008.

\begin{tabular}{|c|c|c|c|c|c|c|c|}
\hline \multirow[b]{2}{*}{ Well } & \multicolumn{2}{|c|}{ Horizontal Location $^{\mathrm{a}}(\mathrm{ft})$} & \multirow{2}{*}{$\begin{array}{c}\text { Top of } \\
\text { Casing } \\
\text { Elevation }^{b} \\
\text { (ft AMSL) }^{c}\end{array}$} & \multicolumn{2}{|c|}{$\begin{array}{c}\text { Groundwater Level on } \\
\text { November } 12,2007\end{array}$} & \multicolumn{2}{|c|}{$\begin{array}{c}\text { Groundwater Level on } \\
\text { March } 12-20,2008 \\
\end{array}$} \\
\hline & Northing & Easting & & $\begin{array}{l}\text { Depth } \\
\left(\mathrm{ft} \mathrm{TOC}^{\mathrm{d}}{ }^{\mathrm{d}}\right.\end{array}$ & $\begin{array}{l}\text { Elevation } \\
\text { (ft AMSL) }\end{array}$ & $\begin{array}{l}\text { Depth } \\
\text { (ft TOC) }\end{array}$ & $\begin{array}{l}\text { Elevation } \\
\text { (ft AMSL) }\end{array}$ \\
\hline MW01 & 515257.2 & 1839058.4 & 1329.30 & 13.95 & 1315.35 & 11.89 & 1317.41 \\
\hline MW02 & 515079.9 & 1839143.0 & 1334.82 & 22.68 & 1312.14 & 21.85 & 1312.97 \\
\hline MW03 & 514935.9 & 1839135.8 & 1334.70 & 22.54 & 1312.16 & 21.22 & 1313.48 \\
\hline MW04 & 514942.5 & 1838880.5 & 1322.71 & 26.06 & 1296.65 & 24.23 & 1298.48 \\
\hline MW05 & 515049.6 & 1838835.0 & 1318.11 & 10.49 & 1307.62 & 7.32 & 1310.79 \\
\hline MW06 & 514922.3 & 1839011.2 & 1329.82 & 38.47 & 1291.35 & 34.70 & 1295.12 \\
\hline MW07 & 514889.0 & 1838906.8 & 1324.83 & 29.59 & 1295.24 & 28.32 & 1296.51 \\
\hline MW08 & 514939.6 & 1839294.4 & 1332.41 & 20.40 & 1312.01 & 18.85 & 1313.56 \\
\hline MW09 & 515104.0 & 1838737.4 & 1310.49 & 2.89 & 1307.60 & 0.00 & 1310.49 \\
\hline MW10 & 514909.9 & 1839205.5 & 1334.56 & 22.36 & 1312.20 & 20.90 & 1313.66 \\
\hline SB01 & 514987.3 & 1838927.1 & 1325.16 & 19.72 & 1305.44 & 15.87 & 1309.29 \\
\hline SB04 & 514979.9 & 1839195.6 & 1335.73 & 23.68 & 1312.05 & 22.34 & 1313.39 \\
\hline SB07R & 515059.3 & 1839067.0 & 1331.71 & 19.56 & 1312.15 & 7.43 & 1313.85 \\
\hline SB08 & 515167.1 & 1839120.5 & 1332.56 & 20.49 & 1312.07 & 18.23 & 1313.48 \\
\hline SB09 & 514805.7 & 1838653.4 & 1311.04 & 6.27 & 1304.77 & 19.24 & 1313.32 \\
\hline
\end{tabular}

a Horizontal coordinates are target location centers. Northings and eastings are Kansas State Plane Coordinates. Horizontal datum is North American Datum (NAD) 83.

b Vertical datum is National Geodetic Vertical Datum (NGVD) 88.

c AMSL, above mean sea level.

d TOC, below top of casing.

Source of location data: Schwab-Eaton, Manhattan, Kansas. 
TABLE 3.2 Analytical results from the AGEM Laboratory for volatile organic compounds in groundwater samples collected at Centralia, August 2004 to March 2008.

\begin{tabular}{|c|c|c|c|c|c|c|}
\hline \multirow[b]{2}{*}{ Well } & \multirow[b]{2}{*}{$\begin{array}{l}\text { Screen } \\
\text { Interval } \\
\text { (ft BGL) }\end{array}$} & \multirow[b]{2}{*}{ Sample } & \multirow[b]{2}{*}{$\begin{array}{l}\text { Sample } \\
\text { Date }\end{array}$} & \multicolumn{3}{|c|}{ Concentration $(\mu \mathrm{g} / \mathrm{L})$} \\
\hline & & & & $\begin{array}{c}\text { Carbon } \\
\text { Tetrachloride }\end{array}$ & Chloroform & $\begin{array}{l}\text { Methylene } \\
\text { Chloride }\end{array}$ \\
\hline \multirow[t]{8}{*}{ MW01 } & $54.5-64.5$ & CNMW01-W-16158 & $8 / 24 / 04$ & $\mathrm{ND}^{\mathrm{a}}$ & ND & ND \\
\hline & & CNMW01-W-19276 & 9/10/05 & ND & ND & ND \\
\hline & & CNMW01-W-16308 & $10 / 11 / 05$ & ND & ND & ND \\
\hline & & CNMW01-W-19890 & $3 / 15 / 06$ & ND & ND & ND \\
\hline & & CNMW01-W-22501 & $9 / 25 / 06$ & ND & ND & ND \\
\hline & & CNMW01-W-16326 & $3 / 29 / 07$ & ND & ND & ND \\
\hline & & CNMW01-W-16228 & $9 / 26 / 07$ & $1.0 \mathrm{R}^{\mathrm{b}}$ & ND & ND \\
\hline & & CNMW01-W-26023 & $3 / 19 / 08$ & ND & ND & ND \\
\hline \multirow[t]{8}{*}{ MW02 } & $49.5-59.5$ & CNMW02-W-16159 & $8 / 26 / 04$ & 215 & 6.2 & ND \\
\hline & & CNMW02-W-19282 & 9/11/05 & 776 & 33 & ND \\
\hline & & CNMW02-W-16309 & $10 / 12 / 05$ & 528 & 21 & ND \\
\hline & & CNMW02-W-19908 & 3/16/06 & 847 & 21 & ND \\
\hline & & CNMW02-W-22508 & $9 / 26 / 06$ & 1233 & 25 & ND \\
\hline & & CNMW02-W-15489 & $3 / 26 / 07$ & 829 & 14 & ND \\
\hline & & CNMW02-W-16227 & $9 / 26 / 07$ & 1138 & 18 & ND \\
\hline & & CNMW02-W-26000 & $3 / 12 / 08$ & ND & 1.2 & 1.9 \\
\hline \multirow[t]{8}{*}{ MW03 } & $50.5-60.5$ & CNMW03-W-16178 & $8 / 24 / 04$ & 1.2 & ND & ND \\
\hline & & CNMW03-W-19277 & 9/10/05 & 1.6 & ND & ND \\
\hline & & CNMW03-W-16310 & $10 / 11 / 05$ & 1.8 & ND & ND \\
\hline & & CNMW03-W-19909 & 3/17/06 & 2.6 & $0.2 \mathrm{Jc}$ & ND \\
\hline & & CNMW03-W-22513 & 9/26/06 & 2.7 & ND & ND \\
\hline & & CNMW03-W-15494 & $3 / 27 / 07$ & 2.5 & ND & ND \\
\hline & & CNMW03-W-16223 & $9 / 25 / 07$ & 3.5 & ND & ND \\
\hline & & CNMW03-W-26001 & $3 / 12 / 08$ & 2.3 & ND & ND \\
\hline \multirow[t]{8}{*}{ MW04 } & $37.5-47.5$ & CNMW04-W-16180 & $8 / 24 / 04$ & ND & ND & ND \\
\hline & & CNMW04-W-19280 & 9/11/05 & $0.9 \mathrm{~J}$ & ND & ND \\
\hline & & CNMW04-W-16311 & 10/11/05 & $0.8 \mathrm{~J}$ & ND & ND \\
\hline & & CNMW04-W-19891 & 3/15/06 & 1.3 & ND & ND \\
\hline & & CNMW04-W-22506 & $9 / 25 / 06$ & 1.4 & $0.1 \mathrm{~J}$ & ND \\
\hline & & CNMW04-W-16210 & $3 / 28 / 07$ & 2.1 & ND & ND \\
\hline & & CNMW04-W-16220 & $9 / 24 / 07$ & 2.0 & ND & ND \\
\hline & & CNMW04-W-26024 & $3 / 19 / 08$ & 1.3 & ND & ND \\
\hline \multirow[t]{8}{*}{ MW05 } & $34.5-44.5$ & CNMW05-W-16183 & $8 / 25 / 04$ & ND & ND & ND \\
\hline & & CNMW05-W-19279 & 9/10/05 & 1.9 & ND & ND \\
\hline & & CNMW05-W-16312 & 10/11/05 & 1.5 & ND & ND \\
\hline & & CNMW05-W-19976 & 3/15/06 & 1.3 & ND & ND \\
\hline & & CNMW05-W-22505 & $9 / 25 / 06$ & 1.3 & ND & ND \\
\hline & & CNMW05-W-16213 & $3 / 28 / 07$ & $0.5 \mathrm{~J}$ & ND & ND \\
\hline & & CNMW05-W-16218 & $9 / 24 / 07$ & 1.2 & ND & ND \\
\hline & & CNMW05-W-26025 & $3 / 19 / 08$ & 1.9 & ND & ND \\
\hline \multirow[t]{8}{*}{ MW06 } & $46.5-56.5$ & CNMW06-W-16184 & $8 / 25 / 04$ & ND & ND & ND \\
\hline & & CNMW06-W-19278 & 9/10/05 & ND & ND & ND \\
\hline & & CNMW06-W-16313 & $10 / 11 / 05$ & $0.3 \mathrm{~J}$ & ND & ND \\
\hline & & CNMW06-W-19889 & 3/15/06 & $0.2 \mathrm{~J}$ & ND & ND \\
\hline & & CNMW06-W-22511 & $9 / 27 / 06$ & ND & ND & ND \\
\hline & & CNMW06-W-16208 & $3 / 27 / 07$ & ND & ND & ND \\
\hline & & CNMW06-W-16222 & $9 / 24 / 07$ & ND & ND & ND \\
\hline & & CNMW06-W-26026 & 3/19/08 & ND & ND & ND \\
\hline
\end{tabular}


TABLE 3.2 (Cont.)

\begin{tabular}{|c|c|c|c|c|c|c|}
\hline \multirow[b]{2}{*}{ Well } & \multirow{2}{*}{$\begin{array}{l}\text { Screen } \\
\text { Interval } \\
\text { (ft BGL) }\end{array}$} & \multirow[b]{2}{*}{ Sample } & \multirow[b]{2}{*}{$\begin{array}{l}\text { Sample } \\
\text { Date }\end{array}$} & \multicolumn{3}{|c|}{ Concentration $(\mu \mathrm{g} / \mathrm{L})$} \\
\hline & & & & $\begin{array}{c}\text { Carbon } \\
\text { Tetrachloride }\end{array}$ & Chloroform & $\begin{array}{c}\text { Methylene } \\
\text { Chloride }\end{array}$ \\
\hline \multirow{5}{*}{ MW07 } & $45-55$ & CNMW07-W-19887 & 3/14/06 & $0.4 \mathrm{~J}$ & $0.6 \mathrm{~J}$ & ND \\
\hline & & CNMW07-W-22512 & 9/26/06 & 1.1 & ND & ND \\
\hline & & CNMW07-W-15492 & $3 / 26 / 07$ & 1.8 & ND & ND \\
\hline & & CNMW07-W-16221 & $9 / 24 / 07$ & 2.4 & ND & ND \\
\hline & & CNMW07-W-26027 & $3 / 19 / 08$ & 3.0 & ND & ND \\
\hline \multirow[t]{5}{*}{ MW08 } & $38-53$ & CNMW08-W-19284 & $3 / 14 / 06$ & ND & ND & ND \\
\hline & & CNMW08-W-22507 & $9 / 26 / 06$ & ND & ND & ND \\
\hline & & CNMW08-W-15493 & $3 / 27 / 07$ & ND & ND & ND \\
\hline & & CNMW08-W-16226 & $9 / 25 / 07$ & ND & ND & ND \\
\hline & & CNMW08-W-26028 & $3 / 20 / 08$ & ND & ND & ND \\
\hline \multirow[t]{5}{*}{ MW09 } & $25-35$ & CNMW09-W-19285 & $3 / 15 / 06$ & ND & ND & ND \\
\hline & & CNMW09-W-22504 & $9 / 25 / 06$ & ND & ND & ND \\
\hline & & CNMW09-W-16209 & $3 / 27 / 07$ & ND & ND & ND \\
\hline & & CNMW09-W-16219 & 9/24/07 & ND & ND & ND \\
\hline & & CNMW09-W-26029 & $3 / 20 / 08$ & ND & ND & ND \\
\hline \multirow[t]{5}{*}{ MW10 } & $30-45$ & CNMW10-W-19886 & $3 / 14 / 06$ & ND & ND & ND \\
\hline & & CNMW10-W-22510 & $9 / 26 / 06$ & ND & ND & ND \\
\hline & & CNMW10-W-16215 & $3 / 28 / 07$ & ND & ND & ND \\
\hline & & CNMW10-W-16224 & $9 / 25 / 07$ & ND & ND & ND \\
\hline & & CNMW10-W-26030 & $3 / 20 / 08$ & ND & ND & ND \\
\hline \multirow[t]{8}{*}{ SB01 } & $40-50$ & CNSB01-W-16188 & $8 / 26 / 04$ & 186 & 6.5 & ND \\
\hline & & CNSB01-W-19274 & 9/9/05 & 269 & 6.8 & ND \\
\hline & & CNSB01-W-16314 & $10 / 12 / 05$ & 288 & 6.6 & ND \\
\hline & & CNSB01-W-19979 & 3/17/06 & 320 & 5.7 & ND \\
\hline & & CNSB01-W-22516 & 9/27/06 & 267 & 6.3 & ND \\
\hline & & CNSB01-W-15491 & $3 / 27 / 07$ & 222 & 4.9 & ND \\
\hline & & CNSB01-W-16232 & 9/27/07 & 283 & 4.6 & ND \\
\hline & & CNSB01-W-26031 & $3 / 20 / 08$ & 325 & 4.8 & ND \\
\hline \multirow[t]{8}{*}{ SB04 } & $51-61$ & CNSB04-W-16189 & $8 / 26 / 04$ & 30 & ND & ND \\
\hline & & CNSB04-W-19273 & 9/9/05 & 47 & $0.6 \mathrm{~J}$ & ND \\
\hline & & CNSB04-W-16315 & $10 / 12 / 05$ & 44 & $0.5 \mathrm{~J}$ & ND \\
\hline & & CNSB04-W-19906 & 3/16/06 & 51 & $0.5 \mathrm{~J}$ & $0.4 \mathrm{~J} \mathrm{~B}^{\mathrm{d}}$ \\
\hline & & CNSB04-W-22503 & $9 / 25 / 06$ & 54 & $0.7 \mathrm{~J}$ & ND \\
\hline & & CNSB04-W-16216 & $3 / 28 / 07$ & 44 & $0.5 \mathrm{~J}$ & ND \\
\hline & & CNSB04-W-16230 & 9/26/07 & 36 & $0.4 \mathrm{~J}$ & ND \\
\hline & & CNSB04-W-26002 & $3 / 12 / 08$ & 30 & $0.3 \mathrm{~J}$ & ND \\
\hline \multirow[t]{8}{*}{ SB05 } & $32-42$ & CNSB05-W-16190 & $8 / 26 / 04$ & 59 & 5.5 & ND \\
\hline & & CNSB05-W-19275 & 9/9/05 & 77 & 7.2 & ND \\
\hline & & CNSB05-W-16323 & $10 / 12 / 05$ & 54 & 5.5 & ND \\
\hline & & CNSB05-W-19904 & 3/17/06 & 104 & 7.2 & ND \\
\hline & & CNSB05-W-19940 & 9/27/06 & 139 & 12 & ND \\
\hline & & CNSB05-W-16212 & $3 / 28 / 07$ & 138 & 12 & ND \\
\hline & & CNSB05-W-16233 & 9/26/07 & 221 & 16 & ND \\
\hline & & CNSB05-W-26032 & $3 / 20 / 08$ & 224 & 17 & ND \\
\hline
\end{tabular}


TABLE 3.2 (Cont.)

\begin{tabular}{|c|c|c|c|c|c|c|}
\hline \multirow[b]{2}{*}{ Well } & \multirow[b]{2}{*}{$\begin{array}{l}\text { Screen } \\
\text { Interval } \\
\text { (ft BGL) }\end{array}$} & \multirow[b]{2}{*}{ Sample } & \multirow[b]{2}{*}{$\begin{array}{l}\text { Sample } \\
\text { Date }\end{array}$} & \multicolumn{3}{|c|}{ Concentration $(\mu \mathrm{g} / \mathrm{L})$} \\
\hline & & & & $\begin{array}{c}\text { Carbon } \\
\text { Tetrachloride }\end{array}$ & Chloroform & $\begin{array}{l}\text { Methylene } \\
\text { Chloride }\end{array}$ \\
\hline \multirow[t]{5}{*}{ SB07R } & $45-60$ & CNSB07R-W-19978 & 3/15/06 & 41 & 2.7 & ND \\
\hline & & CNSB07R-W-19924 & 9/26/06 & 30 & 1.7 & ND \\
\hline & & CNSB07R-W-15490 & 3/26/07 & 30 & 1.7 & ND \\
\hline & & CNSB07R-W-16225 & 9/25/07 & 50 & 2.4 & ND \\
\hline & & CNSB07R-W-26003 & $3 / 12 / 08$ & 13 & $0.9 \mathrm{~J}$ & ND \\
\hline \multirow[t]{8}{*}{ SB08 } & $52-62$ & CNSB08-W-16192 & $8 / 26 / 04$ & 79 & 3.1 & ND \\
\hline & & CNSB08-W-19272 & 9/8/05 & 80 & 2.6 & ND \\
\hline & & CNSB08-W-16317 & $10 / 12 / 05$ & 77 & 2.8 & ND \\
\hline & & CNSB08-W-19903 & $3 / 17 / 06$ & 91 & 2.7 & ND \\
\hline & & CNSB08-W-22500 & $9 / 21 / 06$ & 53 & 1.6 & ND \\
\hline & & CNSB08-W-16214 & 3/28/07 & 64 & 2.0 & ND \\
\hline & & CNSB08-W-16229 & 9/26/07 & 68 & 1.8 & ND \\
\hline & & CNSB08-W-26004 & $3 / 12 / 08$ & 28 & 1.1 & ND \\
\hline \multirow[t]{8}{*}{ SB09 } & $32-42$ & CNSB09-W-16193 & $8 / 26 / 04$ & ND & ND & ND \\
\hline & & CNSB09-W-19281 & 9/11/05 & ND & ND & ND \\
\hline & & CNSB09-W-16318 & $10 / 11 / 05$ & ND & ND & ND \\
\hline & & CNSB09-W-19902 & $3 / 17 / 06$ & ND & ND & ND \\
\hline & & CNSB09-W-22502 & 9/25/06 & ND & ND & ND \\
\hline & & CNSB09-W-16211 & $3 / 28 / 07$ & ND & ND & ND \\
\hline & & CNSB09-W-16231 & 9/26/07 & ND & ND & ND \\
\hline & & CNSB09-W-26033 & 3/20/08 & ND & ND & ND \\
\hline
\end{tabular}

a ND, not detected at an instrument detection limit of $0.1 \mu \mathrm{g} / \mathrm{L}$.

${ }^{\mathrm{b}}$ Qualifier R indicates that the contaminant was present in the associated equipment rinsate.

${ }^{\mathrm{C}}$ Qualifier $\mathrm{J}$ indicates an estimated concentration below the method quantitation limit of $1.0 \mu \mathrm{g} / \mathrm{L}$.

d Qualifier B indicates that the contaminant was present in the associated method blank. 
TABLE 3.3 Field measurements for groundwater samples collected at Centralia, August 2004 to March 2008.

\begin{tabular}{|c|c|c|c|c|c|c|c|c|c|}
\hline \multirow[b]{2}{*}{ Location } & \multirow{2}{*}{$\begin{array}{l}\text { Screen } \\
\text { Interval } \\
\text { (ft BGL) }\end{array}$} & \multirow[b]{2}{*}{$\begin{array}{l}\text { Sample } \\
\text { Date }\end{array}$} & \multirow[b]{2}{*}{$\begin{array}{c}\text { Temperature } \\
\left({ }^{\circ} \mathrm{C}\right)\end{array}$} & \multirow[b]{2}{*}{$\mathrm{pH}$} & \multirow[b]{2}{*}{$\begin{array}{l}\text { Conductivity } \\
(\mu \mathrm{S} / \mathrm{cm})\end{array}$} & \multicolumn{3}{|c|}{ Concentration (mg/L) } & \multirow[b]{2}{*}{$\begin{array}{l}\text { ORP } \\
(\mathrm{mV})\end{array}$} \\
\hline & & & & & & $\begin{array}{l}\text { Dissolved } \\
\text { Oxygen }\end{array}$ & $\begin{array}{l}\text { Carbon } \\
\text { Dioxide }\end{array}$ & Iron(II) & \\
\hline \multirow[t]{8}{*}{ MW01 } & $54.5-64.5$ & $8 / 24 / 04$ & 16.3 & 7.39 & 652 & 0.06 & 25 & 0 & 230 \\
\hline & & 9/10/05 & 16.3 & 7.26 & 599 & 6.31 & $-{ }^{a}$ & 0 & 104 \\
\hline & & $10 / 11 / 05$ & 16.4 & 6.45 & 634 & - & - & - & - \\
\hline & & $3 / 15 / 06$ & 14.3 & 7.56 & 621 & 9.33 & 30 & 0.04 & 297 \\
\hline & & $9 / 25 / 06$ & 13.3 & 7.01 & 782 & 6.82 & 50 & 0.31 & 92 \\
\hline & & $3 / 29 / 07$ & 16.5 & 6.54 & 629 & 4.39 & - & 0 & 174 \\
\hline & & $9 / 26 / 07$ & 17.8 & 7.06 & 630 & 0.89 & 35 & 0.09 & 146 \\
\hline & & $3 / 19 / 08$ & 9.5 & 7.31 & 613 & 3.34 & - & - & 122 \\
\hline \multirow[t]{8}{*}{ MW02 } & $49.5-59.5$ & $8 / 26 / 04$ & 14.4 & 7.31 & 729 & 0.16 & 20 & 0.12 & 235 \\
\hline & & 9/11/05 & 15.3 & 7.02 & 739 & 1.28 & - & - & - \\
\hline & & $10 / 12 / 05$ & 14.8 & 6.60 & 766 & - & - & - & - \\
\hline & & 3/16/06 & 14.2 & 6.78 & 759 & 1.24 & - & 0 & 295 \\
\hline & & $9 / 26 / 06$ & 13.2 & 6.98 & 957 & 3.05 & 40 & 0.06 & 67 \\
\hline & & $3 / 26 / 07$ & 15.7 & 6.39 & 739 & 2.29 & 50 & - & 67 \\
\hline & & $9 / 26 / 07$ & 15.4 & 7.04 & 763 & 3.39 & 25 & 0 & 156 \\
\hline & & $3 / 12 / 08$ & 11.1 & 5.58 & 10174 & 0.28 & - & $3.3^{b}$ & -42 \\
\hline \multirow[t]{8}{*}{ MW03 } & $50.5-60.5$ & $8 / 24 / 04$ & 13.1 & 7.28 & 783 & 0.10 & 55 & 0.21 & 230 \\
\hline & & 9/10/05 & 15.1 & 7.05 & 715 & 10.42 & 65 & 0 & 142 \\
\hline & & $10 / 11 / 05$ & 16.3 & 6.46 & 765 & - & - & - & - \\
\hline & & $3 / 17 / 06$ & 13.8 & 6.75 & 753 & 9.39 & 77 & 0 & 290 \\
\hline & & 9/26/06 & 13.2 & 6.92 & 960 & 11.57 & 45 & 0.08 & 251 \\
\hline & & $3 / 27 / 07$ & 15.3 & 6.40 & 774 & 7.73 & 25 & - & 268 \\
\hline & & $9 / 25 / 07$ & 14.3 & 6.97 & 738 & 8.44 & 30 & 0 & 162 \\
\hline & & $3 / 12 / 08$ & 14.6 & 7.12 & 777 & 7.90 & - & 3.13 & 88 \\
\hline \multirow[t]{8}{*}{ MW04 } & $37.5-47.5$ & $8 / 24 / 04$ & 16.2 & 7.39 & 717 & 0.11 & 40 & 0.04 & 210 \\
\hline & & 9/11/05 & 15.4 & 7.18 & 665 & 8.43 & 60 & 0 & 226 \\
\hline & & $10 / 11 / 05$ & 14.4 & 7.14 & 811 & - & - & - & - \\
\hline & & 3/15/06 & 13.5 & 7.78 & 675 & 6.82 & 55 & 0.06 & 283 \\
\hline & & $9 / 25 / 06$ & - & 7.02 & 613 & 9.13 & 40 & 0.19 & 46 \\
\hline & & $3 / 28 / 07$ & 15.4 & 6.47 & 678 & 5.46 & - & 0 & 197 \\
\hline & & $9 / 24 / 07$ & 17.4 & 7.10 & 667 & 6.94 & 35 & 0.24 & 261 \\
\hline & & 3/19/08 & 11.2 & 7.32 & 636 & 7.55 & - & - & 164 \\
\hline \multirow[t]{8}{*}{ MW05 } & $34.5-44.5$ & $8 / 25 / 04$ & 14.3 & 7.14 & 613 & 0.08 & 25 & 0.06 & 215 \\
\hline & & $9 / 10 / 05$ & 14.2 & 6.80 & 620 & 1.40 & 110 & 0 & 160 \\
\hline & & $10 / 11 / 05$ & 14.8 & 6.35 & 610 & - & - & - & - \\
\hline & & 3/15/06 & 14.3 & 6.90 & 701 & 0.90 & 30 & 0.06 & 156 \\
\hline & & $9 / 25 / 06$ & 13.6 & 6.95 & 768 & 0.09 & 50 & 0.02 & 55 \\
\hline & & $3 / 28 / 07$ & 14.4 & 6.44 & 573 & 4.53 & 35 & 0 & 295 \\
\hline & & $9 / 24 / 07$ & 15.8 & 7.06 & 368 & 3.09 & 45 & 0 & 182 \\
\hline & & 3/19/08 & 12.9 & 7.42 & 642 & 5.42 & - & - & 177 \\
\hline \multirow[t]{8}{*}{ MW06 } & $46.5-56.5$ & $8 / 25 / 04$ & 15.9 & 7.50 & 637 & 0.05 & 15 & 0 & 215 \\
\hline & & 9/10/05 & 14.6 & 7.23 & 659 & 0.04 & 60 & 0 & 41 \\
\hline & & $10 / 11 / 05$ & 15.8 & 6.99 & 638 & - & - & - & - \\
\hline & & $3 / 15 / 06$ & 14.1 & 7.38 & 630 & 9.87 & 35 & 0.02 & 263 \\
\hline & & 9/27/06 & 13.1 & 6.16 & 652 & 0.05 & 45 & 1.12 & 63 \\
\hline & & $3 / 27 / 07$ & 19.0 & 6.42 & 466 & 0.11 & 20 & 0 & 13 \\
\hline & & $9 / 24 / 07$ & 16.8 & 7.11 & 463 & 8.00 & 25 & 0.41 & 191 \\
\hline & & 3/19/08 & 14.1 & 7.01 & 552 & 7.00 & - & - & 172 \\
\hline
\end{tabular}


TABLE 3.3 (Cont.)

\begin{tabular}{|c|c|c|c|c|c|c|c|c|c|}
\hline \multirow[b]{2}{*}{ Location } & \multirow{2}{*}{$\begin{array}{l}\text { Screen } \\
\text { Interval } \\
\text { (ft BGL) }\end{array}$} & \multirow[b]{2}{*}{$\begin{array}{l}\text { Sample } \\
\text { Date }\end{array}$} & \multirow[b]{2}{*}{$\begin{array}{c}\text { Temperature } \\
\left({ }^{\circ} \mathrm{C}\right)\end{array}$} & \multirow[b]{2}{*}{$\mathrm{pH}$} & \multirow[b]{2}{*}{$\begin{array}{l}\text { Conductivity } \\
(\mu \mathrm{S} / \mathrm{cm})\end{array}$} & \multicolumn{3}{|c|}{ Concentration (mg/L) } & \multirow[b]{2}{*}{$\begin{array}{l}\text { ORP } \\
(\mathrm{mV})\end{array}$} \\
\hline & & & & & & $\begin{array}{l}\text { Dissolved } \\
\text { Oxygen }\end{array}$ & $\begin{array}{l}\text { Carbon } \\
\text { Dioxide }\end{array}$ & Iron(II) & \\
\hline \multirow[t]{5}{*}{ MW07 } & $45-55$ & $3 / 14 / 06$ & 14.7 & 6.61 & 709 & 0.34 & - & 0.03 & 143 \\
\hline & & $9 / 26 / 06$ & 13.1 & 7.23 & 642 & 2.91 & 50 & 0 & - \\
\hline & & $3 / 26 / 07$ & 15.8 & 6.50 & 642 & 1.87 & 30 & 0 & 261 \\
\hline & & $9 / 24 / 07$ & 19.0 & 7.18 & 609 & 9.05 & 60 & 0.18 & 190 \\
\hline & & $3 / 19 / 08$ & 12.5 & 7.29 & 647 & 2.70 & - & - & 215 \\
\hline \multirow[t]{5}{*}{ MW08 } & $38-53$ & $3 / 14 / 06$ & 13.5 & 6.35 & 854 & 5.32 & - & 0 & 145 \\
\hline & & $9 / 26 / 06$ & 13.3 & 6.75 & 1095 & 0.16 & 50 & 0.18 & 37 \\
\hline & & $3 / 27 / 07$ & 15.8 & 6.31 & 874 & 1.49 & 30 & 0.21 & 237 \\
\hline & & $9 / 25 / 07$ & 15.8 & 6.92 & 627 & 1.42 & 45 & 0.14 & 219 \\
\hline & & $3 / 20 / 08$ & 13.5 & 7.19 & 869 & 2.11 & - & - & 185 \\
\hline \multirow[t]{5}{*}{ MW09 } & $25-35$ & $3 / 15 / 06$ & 17.7 & 7.33 & 664 & 0.95 & 55 & 0.09 & 214 \\
\hline & & $9 / 25 / 06$ & 12.8 & 6.87 & 859 & 1.59 & 45 & 0.18 & 90 \\
\hline & & $3 / 27 / 07$ & 14.9 & 6.35 & 689 & 4.10 & 30 & 0.69 & 152 \\
\hline & & $9 / 24 / 07$ & 16.6 & 6.94 & 1999 & 3.86 & 55 & 0.14 & 186 \\
\hline & & $3 / 20 / 08$ & 13.5 & 7.17 & 720 & 4.70 & - & - & 173 \\
\hline \multirow[t]{5}{*}{ MW10 } & $30-45$ & $3 / 14 / 06$ & 14.8 & 6.60 & 834 & 6.42 & 65 & 0 & 166 \\
\hline & & $9 / 26 / 06$ & 13.6 & 6.87 & 1058 & 6.94 & 50 & 0.50 & 51 \\
\hline & & $3 / 28 / 07$ & 17.0 & 6.36 & 834 & 5.09 & 35 & 0 & 270 \\
\hline & & $9 / 25 / 07$ & 15.8 & 6.94 & 827 & 6.64 & 35 & 0.21 & 199 \\
\hline & & $3 / 20 / 08$ & 10.9 & 7.18 & 898 & 6.12 & - & - & 187 \\
\hline \multirow[t]{8}{*}{ SB01 } & $40-50$ & $8 / 26 / 04$ & 26.0 & 7.46 & 699 & 5.21 & 30 & 0 & 210 \\
\hline & & 9/9/05 & 25.0 & 7.11 & 674 & 6.25 & 95 & 0 & 140 \\
\hline & & $10 / 12 / 05$ & 13.8 & 7.23 & 686 & - & - & - & - \\
\hline & & $3 / 17 / 06$ & 12.4 & 7.30 & 692 & 5.98 & 55 & 0 & 185 \\
\hline & & 9/27/06 & 14.4 & 7.03 & 832 & 6.54 & 40 & 0.52 & 198 \\
\hline & & $3 / 27 / 07$ & 18.0 & 6.37 & 659 & 3.81 & 25 & 0.23 & 173 \\
\hline & & $9 / 27 / 07$ & 13.5 & 7.24 & 720 & 6.55 & 45 & 1.04 & 143 \\
\hline & & $3 / 20 / 08$ & 15.6 & 7.29 & 783 & 8.02 & - & - & 182 \\
\hline \multirow[t]{8}{*}{ SB04 } & $51-61$ & $8 / 26 / 04$ & 17.9 & 7.14 & 765 & 3.78 & 55 & 0.37 & 230 \\
\hline & & 9/9/05 & 16.0 & 7.09 & 708 & 8.67 & 100 & - & 206 \\
\hline & & $10 / 12 / 05$ & 13.9 & 7.17 & 813 & - & - & - & - \\
\hline & & $3 / 16 / 06$ & 13.0 & 7.57 & 799 & 5.96 & 30 & - & 276 \\
\hline & & $9 / 25 / 06$ & 14.9 & 7.16 & 791 & 9.32 & 70 & 1.18 & 64 \\
\hline & & $3 / 28 / 07$ & 16.2 & 6.45 & 850 & 6.18 & - & 0.23 & 266 \\
\hline & & $9 / 26 / 07$ & 19.8 & 7.03 & 760 & 6.61 & 30 & 0 & 202 \\
\hline & & $3 / 12 / 08$ & 15.5 & 7.04 & 819 & 6.16 & - & 0.09 & 154 \\
\hline \multirow[t]{8}{*}{ SB05 } & $32-42$ & $8 / 26 / 04$ & 15.7 & 7.25 & 761 & - & 25 & 0.06 & 220 \\
\hline & & 9/9/05 & 16.9 & 6.98 & 687 & 7.58 & 100 & - & - \\
\hline & & $10 / 12 / 05$ & 14.0 & 7.00 & 728 & - & - & - & - \\
\hline & & $3 / 17 / 06$ & 13.3 & 7.67 & 718 & 4.80 & 40 & 0.18 & 253 \\
\hline & & $9 / 27 / 06$ & 13.7 & 6.58 & 763 & 4.70 & 50 & 0.25 & 78 \\
\hline & & $3 / 28 / 07$ & 16.7 & 4.03 & 0.11 & 2.58 & 35 & 0.07 & 296 \\
\hline & & $9 / 26 / 07$ & 15.1 & 6.98 & 810 & 4.10 & 30 & 0.5 & 221 \\
\hline & & $3 / 20 / 08$ & 14.5 & 7.11 & 870 & 5.56 & - & - & 206 \\
\hline \multirow[t]{5}{*}{ SB07R } & $45-60$ & $3 / 15 / 06$ & 16.8 & 7.24 & 685 & 7.41 & 60 & 0.08 & 83 \\
\hline & & $9 / 26 / 06$ & 13.2 & 6.89 & 842 & 6.17 & 55 & 0.26 & 67 \\
\hline & & $3 / 26 / 07$ & 19.0 & 6.38 & 668 & 5.08 & 40 & 0.07 & 237 \\
\hline & & $9 / 25 / 07$ & 17.4 & 7.06 & 642 & 6.30 & 35 & 0.11 & 170 \\
\hline & & $3 / 12 / 08$ & 17.3 & 7.18 & 639 & 5.33 & - & 0 & 108 \\
\hline
\end{tabular}


TABLE 3.3 (Cont.)

\begin{tabular}{|c|c|c|c|c|c|c|c|c|c|}
\hline \multirow[b]{2}{*}{ Location } & \multirow{2}{*}{$\begin{array}{l}\text { Screen } \\
\text { Interval } \\
\text { (ft BGL) }\end{array}$} & \multirow[b]{2}{*}{$\begin{array}{l}\text { Sample } \\
\text { Date }\end{array}$} & \multirow[b]{2}{*}{$\begin{array}{c}\text { Temperature } \\
\left({ }^{\circ} \mathrm{C}\right)\end{array}$} & \multirow[b]{2}{*}{$\mathrm{pH}$} & \multirow[b]{2}{*}{$\begin{array}{l}\text { Conductivity } \\
(\mu \mathrm{S} / \mathrm{cm})\end{array}$} & \multicolumn{3}{|c|}{ Concentration (mg/L) } & \multirow[b]{2}{*}{$\begin{array}{l}\text { ORP } \\
(\mathrm{mV})\end{array}$} \\
\hline & & & & & & $\begin{array}{l}\text { Dissolved } \\
\text { Oxygen }\end{array}$ & $\begin{array}{l}\text { Carbon } \\
\text { Dioxide }\end{array}$ & Iron(II) & \\
\hline \multirow[t]{8}{*}{ SB08 } & $52-62$ & 8/26/04 & 19.5 & 7.31 & 635 & 0.16 & 20 & 0.53 & 235 \\
\hline & & 9/8/05 & 21.2 & 7.27 & 598 & 3.21 & 75 & 0 & 111 \\
\hline & & $10 / 12 / 05$ & 13.9 & 7.15 & 630 & - & - & - & - \\
\hline & & $3 / 17 / 06$ & 12.9 & 7.14 & 645 & 3.40 & 40 & 0 & 246 \\
\hline & & 9/21/06 & 14.1 & 6.96 & 809 & 4.53 & 40 & 0 & 37 \\
\hline & & $3 / 28 / 07$ & 15.8 & 6.53 & 645 & 3.57 & 35 & 0.24 & 208 \\
\hline & & $9 / 26 / 07$ & 17.4 & 7.11 & 617 & 4.56 & 40 & 0.77 & 156 \\
\hline & & $3 / 12 / 08$ & 17.1 & 7.17 & 642 & 3.63 & - & 0.14 & 102 \\
\hline \multirow[t]{8}{*}{ SB09 } & $32-42$ & 8/26/04 & 30.9 & 7.09 & 910 & 0.26 & 75 & 0 & 185 \\
\hline & & 9/11/05 & 14.6 & 6.71 & 877 & 0.13 & 225 & 0 & - \\
\hline & & 10/11/05 & 13.9 & 6.85 & 910 & - & - & - & - \\
\hline & & 3/17/06 & 11.7 & 7.03 & 969 & 1.53 & 99 & 0 & 206 \\
\hline & & $9 / 25 / 06$ & 14.2 & 7.00 & 976 & 0.29 & 70 & 0.38 & 86 \\
\hline & & $3 / 28 / 07$ & 14.3 & 6.32 & 957 & 0.89 & 40 & 0.09 & 236 \\
\hline & & $9 / 26 / 07$ & 15.2 & 6.77 & 969 & 1.53 & 45 & 0.12 & 199 \\
\hline & & $3 / 20 / 08$ & 10.1 & 6.94 & 1000 & 1.57 & - & - & 221 \\
\hline
\end{tabular}

a Measurement not recorded.

${ }^{\mathrm{b}}$ Maximum reading from instrument. 


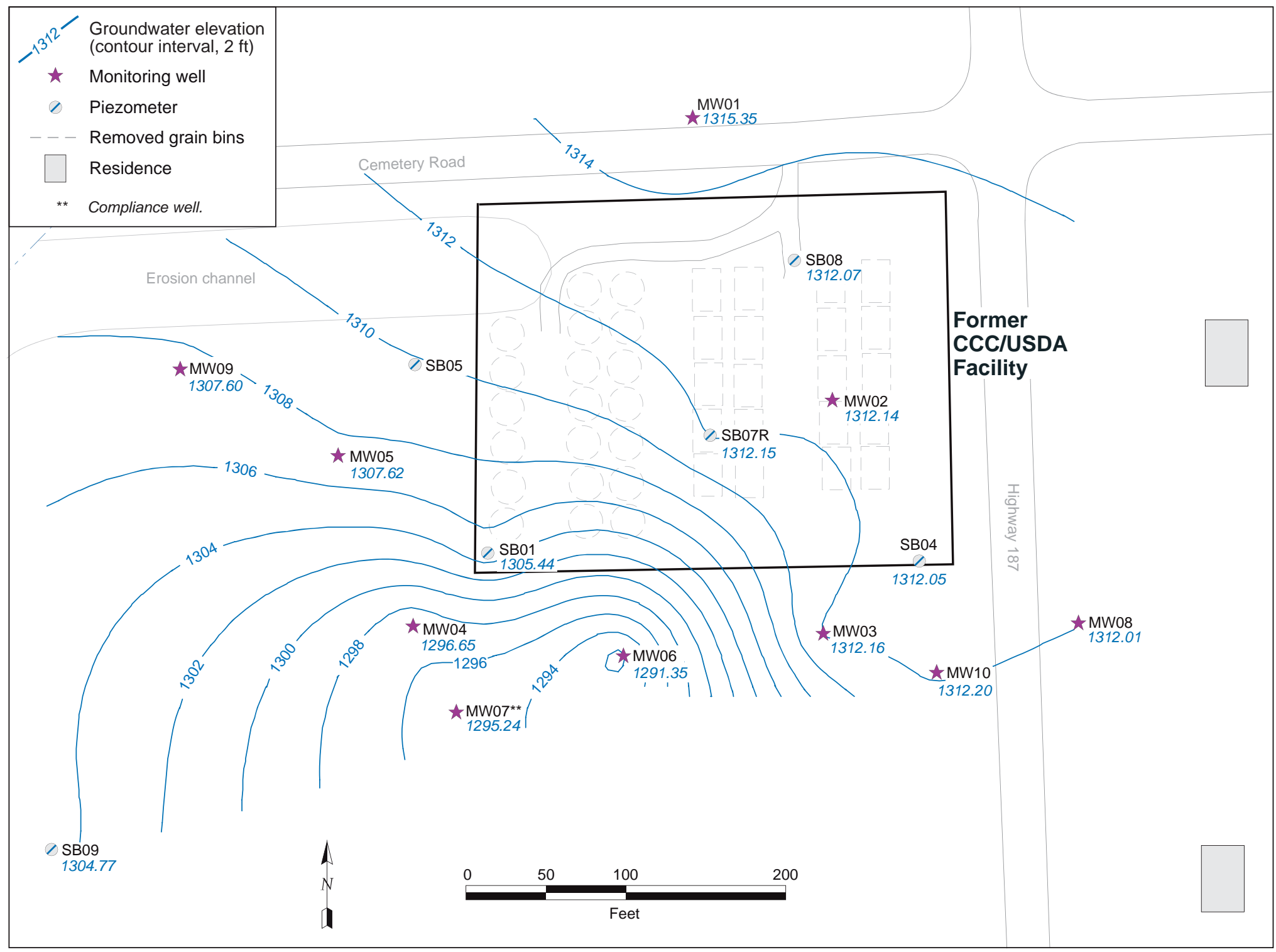

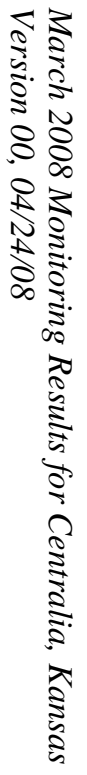

FIGURE 3.1 Potentiometric surface at Centralia, based on water levels measured manually on November 12, 2007. 


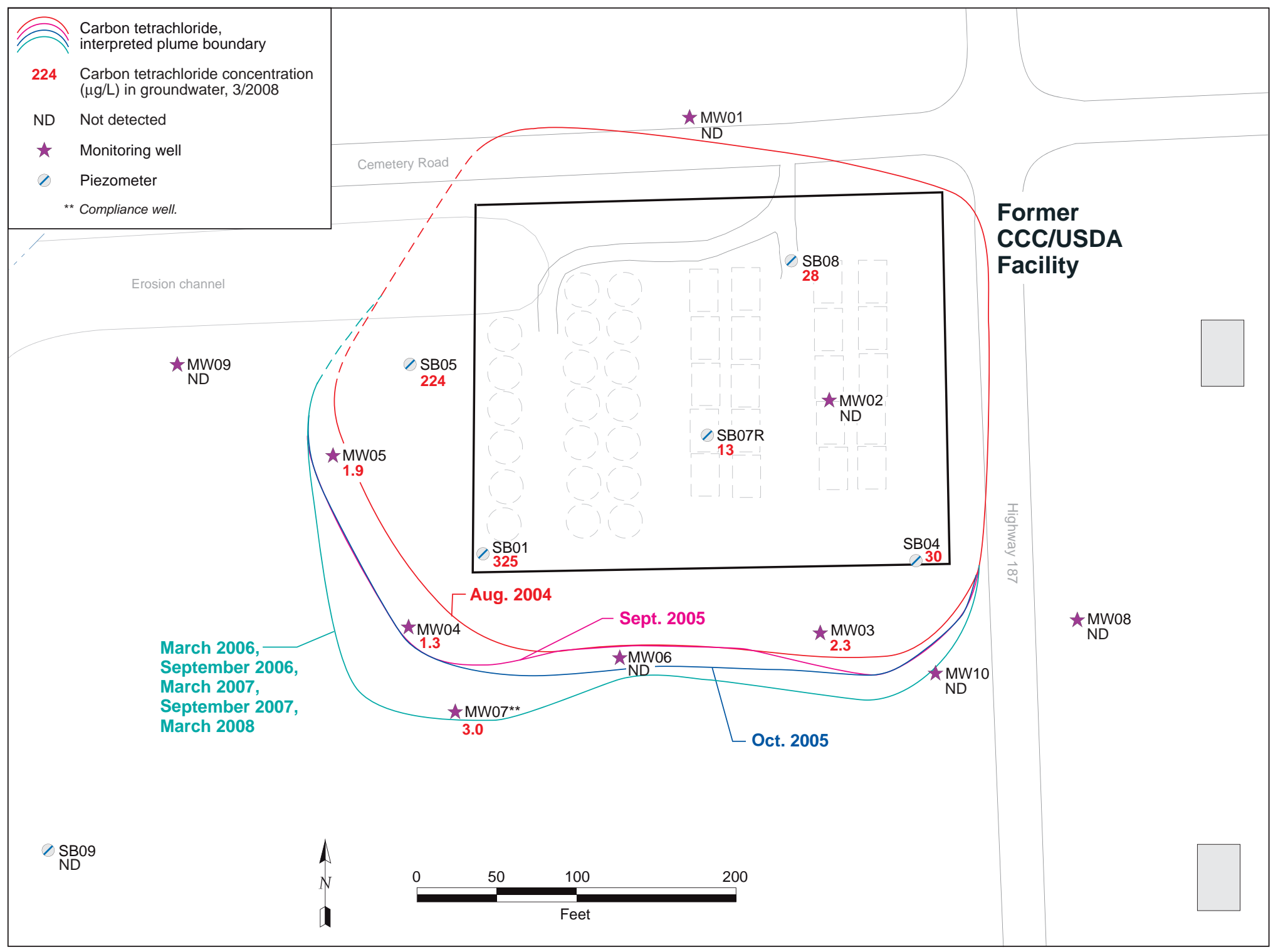

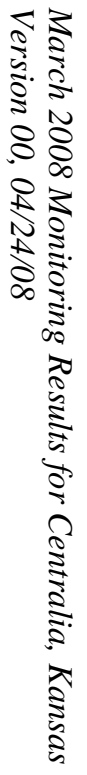

FIGURE 3.2 Carbon tetrachloride levels in groundwater at Centralia in March 2008, with the interpreted lateral extent of the contaminant at intervals during the period August 2004 to March 2008. 


\section{Conclusions and Recommendations}

\subsection{Conclusions}

The findings of the March 2008 monitoring event at Centralia support the following conclusions:

- Measurements of groundwater levels obtained manually and through the use of automatic recorders have consistently indicated an apparent direction of groundwater flow to the south-southwest across the former CCC/USDA facility.

- The March 2008 well sampling data are generally consistent with previous results. Longer-term trends of increasing carbon tetrachloride concentrations continue to be observed at monitoring points SB05, MW03, and MW07, along the western and southern margins of the groundwater plume. These trends suggest slow expansion of the plume at the downgradient locations.

- A decrease in carbon tetrachloride concentrations noted at MW02 is related to the Interim Measure pilot test initiated in December 2007. The results of the pilot test will be reported separately.

- Sampling in 2004-2007 yielded only limited evidence for the presence of subsurface conditions at Centralia conducive to anaerobic degradation of the carbon tetrachloride contamination in groundwater. Nevertheless, consistent detection of chloroform at relatively elevated concentrations at monitoring points SB01, SB05, and MW02 suggested that degradation of carbon tetrachloride was occurring at those locations.

\subsection{Recommendations}

The CCC/USDA developed an Interim Measure Conceptual Design (Argonne 2007b), proposing a pilot test of the Adventus EHC in situ chemical reduction (ISCR) technology, that 
was approved by the KDHE in November 2007 (KDHE 2007). Further information about the Adventus ISCR product is available online (http://www.adventusgroup.com/pdfs/Release-ISCRISCO.pdf).

Groundwater sampling was incorporated into the design of the pilot test, to be implemented as part of the compliance monitoring program to evaluate the effectiveness of the EHC remediation technology at the Centralia site. Implementation of the proposed interim measure occurred in December 2007. The results of the September 2007 monitoring (Argonne 2008) served as pre-injection baseline data for existing monitoring points, per agreement with the KDHE.

The September 2007 sampling was the final monitoring event performed under the twoyear program (Argonne 2005b) approved by the KDHE. The March 2008 sampling began an extension of the twice yearly monitoring that is to continue until the final site remedy has been implemented and a comprehensive program of performance and compliance monitoring has been established (KDHE 2008a). 


\section{References}

Argonne, 2002, Final Master Work Plan: Environmental Investigations at Former CCC/USDA Facilities in Kansas, 2002 Revision, ANL/ER/TR-02/004, prepared for the Commodity Credit Corporation, U.S. Department of Agriculture, Washington, D.C., by Argonne National Laboratory, Argonne, Illinois, December.

Argonne, 2003, Final Phase I Report and Phase II Work Plan: QuickSite ${ }^{\circledR}$ Investigation, Centralia, Kansas, ANL/ER/TR-02/009, prepared for the Commodity Credit Corporation, U.S. Department of Agriculture, Washington, D.C., by Argonne National Laboratory, Argonne, Illinois, March.

Argonne, 2004, Final Phase II Report: QuickSite ${ }^{\circledR}$ Investigation, Centralia, Kansas, ANL/ER/TR-03/006, prepared for the Commodity Credit Corporation, U.S. Department of Agriculture, Washington, D.C., by Argonne National Laboratory, Argonne, Illinois, March.

Argonne, 2005a, Final Report: 2004 Monitoring Well Installation and Sampling at Centralia, Kansas, ANL/ER/TR-04/011, prepared for the Commodity Credit Corporation, U.S. Department of Agriculture, Washington, D.C., by Argonne National Laboratory, Argonne, Illinois, October.

Argonne, 2005b, Final Work Plan: Groundwater Monitoring at Centralia, Kansas, ANL/ER/TR-05/004, prepared for the Commodity Credit Corporation, U.S. Department of Agriculture, Washington, D.C., by Argonne National Laboratory, Argonne, Illinois, August.

Argonne, 2006a, Final Report: Groundwater Monitoring at Centralia, Kansas, in SeptemberOctober 2005 and March 2006, with Expansion of the Monitoring Network in January 2006, ANL/EVS/AGEM/TR-06-06, prepared for the Commodity Credit Corporation, U.S. Department of Agriculture, Washington, D.C., by Argonne National Laboratory, Argonne, Illinois, October.

Argonne, 2006b, September 2006 Monitoring Results for Centralia, Kansas, ANL/EVS/AGEM/CHRON-1003, prepared for the Commodity Credit Corporation, U.S. Department of Agriculture, Washington, D.C., by Argonne National Laboratory, Argonne, Illinois, November 10. 
Argonne, 2007a, March 2007 Monitoring Results for Centralia, Kansas, ANL/EVS/AGEM/TR07-08, prepared for the Commodity Credit Corporation, U.S. Department of Agriculture, Washington, D.C., by Argonne National Laboratory, Argonne, Illinois, June.

Argonne, 2007b, Interim Measure Conceptual Design for Remediation at the Former CCC/USDA Grain Storage Facility at Centralia, Kansas: Pilot Test and Remedy Implementation, ANL/EVS/AGEM/TR-07-11, prepared for the Commodity Credit Corporation, U.S. Department of Agriculture, Washington, D.C., by Argonne National Laboratory, Argonne, Illinois, October.

Argonne, 2008, September 2007 Monitoring Results for Centralia, Kansas, ANL/EVS/AGEM/TR-08-01, prepared for the Commodity Credit Corporation, U.S. Department of Agriculture, Washington, D.C., by Argonne National Laboratory, Argonne, Illinois, January.

EPA, 1995, Method 524.2: Measurement of Purgeable Organic Compounds in Water by Capillary Column Gas Chromatography/Mass Spectrometry, Revision 4.1, edited by J.W. Munch, National Exposure Research Laboratory, Office of Research and Development, U.S. Environmental Protection Agency, Cincinnati, Ohio.

EPA, 1998, Technical Protocol for Evaluating Natural Attenuation of Chlorinated Solvents in Ground Water, EPA/600/R-98/128, Office of Research and Development, U.S. Environmental Protection Agency, Washington, D.C., September (http://www.epa.gov/superfund/resources/ gwdocs/protocol.htm).

KDHE, 2001, Monitored Natural Attenuation, Policy BER-RS-042, Bureau of Environmental Remediation, Kansas Department of Health and Environment, Topeka, Kansas, March 30 (revised December 18, 2005; http://www.kdheks.gov/ber/policies/BER_RS_042.pdf).

KDHE, 2007, letter from C. Carey (Bureau of Environmental Remediation, Kansas Department of Health and Environment, Topeka, Kansas) to C. Roe (Commodity Credit Corporation, U.S. Department of Agriculture, Washington, D.C.), regarding review of Interim Measure Conceptual Design for Centralia, Kansas, November 9.

KDHE, 2008a, letter from C. Carey (Bureau of Environmental Remediation, Kansas Department of Health and Environment, Topeka, Kansas) to C. Roe (Commodity Credit Corporation, 
U.S. Department of Agriculture, Washington, D.C.), regarding September 2007 Monitoring Results for Centralia, Kansas, March 12.

KDHE, 2008b, electronic mail message from C. Carey (Bureau of Environmental Remediation, Kansas Department of Health and Environment, Topeka, Kansas) to L. LaFreniere (Argonne National Laboratory, Argonne, Illinois), regarding use of the low-flow sampling technique at Centralia, February 11.

KDHE, 2008c, electronic mail message from E. McWilliams (Bureau of Environmental Remediation, Kansas Department of Health and Environment, Topeka, Kansas) to L. Larsen (Larsen and Associates, Inc., Lawrence, Kansas), April 15.

Puls, R.W., and Barcelona, M.J., 1996, "Low-Flow (Minimal Drawdown) Ground-Water Sampling Procedures," EPA/540/S-95/504, in Ground Water Issue, Superfund Technology Support Center for Ground Water, National Risk Management Research Laboratory, Ada, Oklahoma, April (www.epa.gov/tio/tsp/download/lwflw2a.pdf). 


\section{Appendix A:}

\section{Low-Flow Sampling Procedure EPA/540/S-95/504}




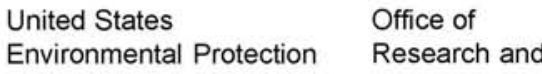 \\ SEPA Ground Water Issue \\ LOW-FLOW (MINIMAL DRAWDOWN) GROUND-WATER SAMPLING PROCEDURES
}

\author{
by Robert W. Puls ${ }^{1}$ and Michael J. Barcelona ${ }^{2}$
}

\section{Background}

The Regional Superfund Ground Water Forum is a group of ground-water scientists, representing EPA's Regional Superfund Offices, organized to exchange information related to ground-water remediation at Superfund sites. One of the major concerns of the Forum is the sampling of ground water to support site assessment and remedial performance monitoring objectives. This paper is intended to provide background information on the development of low-flow sampling procedures and its application under a variety of hydrogeologic settings. It is hoped that the paper will support the production of standard operating procedures for use by EPA Regional personnel and other environmental professionals engaged in ground-water sampling.

For further information contact: Robert Puls, 405-436-8543, Subsurface Remediation and Protection Division, NRMRL, Ada, Oklahoma.

\section{Introduction}

The methods and objectives of ground-water sampling to assess water quality have evolved over time. Initially the emphasis was on the assessment of water quality of aquifers as sources of drinking water. Large water-bearing units were identified and sampled in keeping with that objective. These were highly productive aquifers that supplied drinking water via private wells or through public water supply systems. Gradually, with the increasing awareness of subsurface pollution of these water resources, the understanding of complex hydrogeochemical processes which govern the fate and transport of contaminants in the subsurface increased. This increase in understanding was also due to advances in a number of scientific disciplines and improvements in tools used for site characterization and ground-water sampling. Ground-water quality investigations where pollution was detected initially borrowed ideas, methods, and materials for site characterization from the water supply field and water analysis from public health practices. This included the materials and manner in which monitoring wells were installed and the way in which water was brought to the surface, treated, preserved and analyzed. The prevailing conceptual ideas included convenient generalizations of ground-water resources in terms of large and relatively homogeneous hydrologic units. With time it became apparent that conventional water supply generalizations of homogeneity did not adequately represent field data regarding pollution of these subsurface resources. The important role of heterogeneity became increasingly clear not only in geologic terms, but also in terms of complex physical,

'National Risk Management Research Laboratory, U.S. EPA ${ }^{2}$ University of Michigan

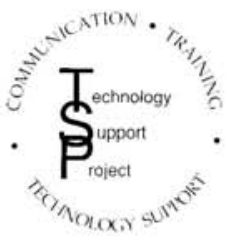

Superfund Technology Support Center for Ground Water

National Risk Management Research Laboratory Subsurface Protection and Remediation Division Robert S. Kerr Environmental Research Center Ada, Oklahoma
Technology Innovation Office Office of Solid Waste and Emergency Response, US EPA, Washington, DC

Walter W. Kovalick, Jr., Ph.D. Director 
chemical and biological subsurface processes. With greater appreciation of the role of heterogeneity, it became evident that subsurface pollution was ubiquitous and encompassed the unsaturated zone to the deep subsurface and included unconsolidated sediments, fractured rock, and aquitards or low-yielding or impermeable formations. Small-scale processes and heterogeneities were shown to be important in identifying contaminant distributions and in controlling water and contaminant flow paths.

It is beyond the scope of this paper to summarize all the advances in the field of ground-water quality investigations and remediation, but two particular issues have bearing on ground-water sampling today: aquifer heterogeneity and colloidal transport. Aquifer heterogeneities affect contaminant flow paths and include variations in geology, geochemistry, hydrology and microbiology. As methods and the tools available for subsurface investigations have become increasingly sophisticated and understanding of the subsurface environment has advanced, there is an awareness that in most cases a primary concern for site investigations is characterization of contaminant flow paths rather than entire aquifers. In fact, in many cases, plume thickness can be less than well screen lengths (e.g., 3-6 m) typically installed at hazardous waste sites to detect and monitor plume movement over time. Small-scale differences have increasingly been shown to be important and there is a general trend toward smaller diameter wells and shorter screens.

The hydrogeochemical significance of colloidal-size particles in subsurface systems has been realized during the past several years (Gschwend and Reynolds, 1987; McCarthy and Zachara, 1989; Puls, 1990; Ryan and Gschwend, 1990). This realization resulted from both field and laboratory studies that showed faster contaminant migration over greater distances and at higher concentrations than flow and transport model predictions would suggest (Buddemeier and Hunt, 1988; Enfield and Bengtsson, 1988; Penrose et al., 1990). Such models typically account for interaction between the mobile aqueous and immobile solid phases, but do not allow for a mobile, reactive solid phase. It is recognition of this third phase as a possible means of contaminant transport that has brought increasing attention to the manner in which samples are collected and processed for analysis (Puls et al., 1990; McCarthy and Degueldre, 1993; Backhus et al., 1993; U. S. EPA, 1995). If such a phase is present in sufficient mass, possesses high sorption reactivity, large surface area, and remains stable in suspension, it can serve as an important mechanism to facilitate contaminant transport in many types of subsurface systems.

Colloids are particles that are sufficiently small so that the surface free energy of the particle dominates the bulk free energy. Typically, in ground water, this includes particles with diameters between 1 and $1000 \mathrm{~nm}$. The most commonly observed mobile particles include: secondary clay minerals; hydrous iron, aluminum, and manganese oxides; dissolved and particulate organic materials, and viruses and bacteria.
These reactive particles have been shown to be mobile under a variety of conditions in both field studies and laboratory column experiments, and as such need to be included in monitoring programs where identification of the total mobile contaminant loading (dissolved + naturally suspended particles) at a site is an objective. To that end, sampling methodologies must be used which do not artificially bias naturally suspended particle concentrations.

Currently the most common ground-water purging and sampling methodology is to purge a well using bailers or high speed pumps to remove 3 to 5 casing volumes followed by sample collection. This method can cause adverse impacts on sample quality through collection of samples with high levels of turbidity. This results in the inclusion of otherwise immobile artifactual particles which produce an overestimation of certain analytes of interest (e.g., metals or hydrophobic organic compounds). Numerous documented problems associated with filtration (Danielsson, 1982; Laxen and Chandler, 1982; Horowitz et al., 1992) make this an undesirable method of rectifying the turbidity problem, and include the removal of potentially mobile (contaminant-associated) particles during filtration, thus artificially biasing contaminant concentrations low. Sampling-induced turbidity problems can often be mitigated by using low-flow purging and sampling techniques.

Current subsurface conceptual models have undergone considerable refinement due to the recent development and increased use of field screening tools. So-called hydraulic push technologies (e.g., cone penetrometer, Geoprobe $\otimes_{1}$, QED HydroPunch $($ ) enable relatively fast screening site characterization which can then be used to design and install a monitoring well network. Indeed, alternatives to conventional monitoring wells are now being considered for some hydrogeologic settings. The ultimate design of any monitoring system should however be based upon adequate site characterization and be consistent with established monitoring objectives.

If the sampling program objectives include accurate assessment of the magnitude and extent of subsurface contamination over time and/or accurate assessment of subsequent remedial performance, then some information regarding plume delineation in three-dimensional space is necessary prior to monitoring well network design and installation. This can be accomplished with a variety of different tools and equipment ranging from hand-operated augers to screening tools mentioned above and large drilling rigs. Detailed information on ground-water flow velocity, direction, and horizontal and vertical variability are essential baseline data requirements. Detailed soil and geologic data are required prior to and during the installation of sampling points. This includes historical as well as detailed soil and geologic logs which accumulate during the site investigation. The use of borehole geophysical techniques is also recommended. With this information (together with other site characterization data) and a clear understanding of sampling 
objectives, then appropriate location, screen length, well diam eter, slot size, etc. for the monitoring well net work can be decided. This is especially critical for newin situ remedial approaches or natural attenuation assessments at hazardous maste sites.

In general, the overall goal of any ground-mater sampling program is to colled water samples with no alteration in water chemistry, analytical dat a thus obtained $m$ ay be used for a variety of specific monitoring programs depending on the regulatory requirements. The sampling m ethodology described in this paper assumes that the monitoring goal is to sample m onitoring vells for the presence of contam inants and it is applicable whether mobile colloids are a concem or not and whether the analytes of concern are metals (and metalloids) or organic com pounds.

\section{Monitoring Objectives and Design Considerations}

The following issues are im portant to consider prior to the design and implementation of any ground-mater monitoring program, induding those which anticipate using low-flow purging and sampling procedures.

\section{A. Data Quality Objectives (DQOs)}

Monitoring objectives include four main types: detection, assessment, corredive-action evaluation and resource evaluation, along with hyorid variations such as siteassessments for property transfers and water availability investigations. Monitoring objectives may change as contam ination or water quality problems are discovered. However, there are a number of comm on components of monitoring programs which should be recognized as im portant regardless of initial objedives. These components include:

1) Developm ent of a conceptual m odel that incorporates elements of the regional geology to the local geologic fram ework. The conceptual model developm ent also includes initial site charaderization efforts to identify hydrostratigraphic units and likely flow-paths using a minimum number of borings and mell completions:

2) Cost-effective and well documented colledion of high quality data utilizing simple, accurate, and reproducible techniques and

3) Refinem ent of the conceptual model based on supplementary data colledion and analysis.

These fundamental com ponents serve many types of monitoring programs and provide a basis for future efforts that evolve in complexity and level of spatial detail as purposes and objectives expand. High quality, reproducible data colledion is a common goal regardless of program objectives.
High quality data colledion implies data of sufficient accuracy, precision, and completeness (i.e., ratio of valid analytical results to the minimum sample number called for by the program design) to meet the program objectives. Acouracy depends on the correct choice of monitoring tools and procedures to $\mathrm{m}$ inimize sample and subsurface disturbance from collection to analysis. Precision depends on the repeatability of sampling and analytical protocols. It can be assured or improved by replication of sample analyses induding blanks, fieldnab standards and reference standards.

\section{B. Sample Repres ent ativeness}

An im portant goal of any monitoring program is collection of data that is truly representative of conditions at the site. The term representativeness applies to chem ical and hydrogeologic data collected via mells, borings, piezom eters, geophysical and soil gas m easurements, lysimeters, and tem porary sam pling points. It involves a recognition of the statistical variability of individual subsurface physical properties, and contam inant or major ion concentration levels, while explaining extreme values. Subsurface temporal and spatial variability are facts. Good professional practice seeks to maximize representativeness by using proven accurate and reproducible techniques to define limits on the distribution of measurem ents collected at a site. However, measures of representativeness are dynam ic and are controlled by evolving site characterization and monitoring objectives. An evolutionary site characterization model, as shown in Figure 1 , provides a systematic approach to the goal of consistent data colledion.

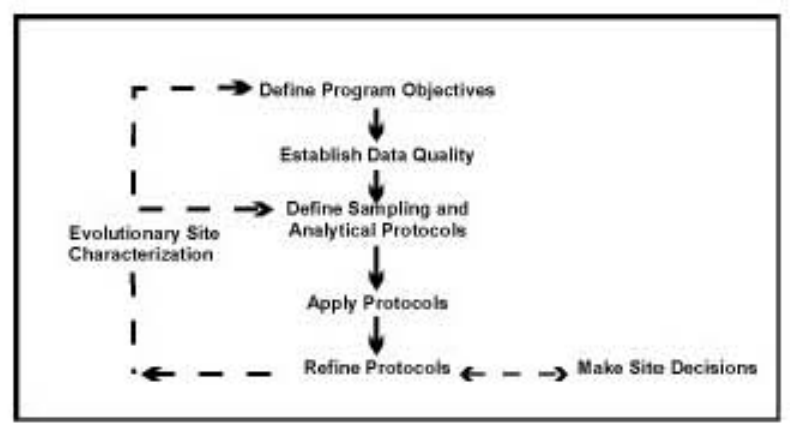

Figure 1. Evolutionany Site Characterization Model

The model emphasizes a recognition of the causes of the variability (e.g., use of inappropriate technology such as using bailers to purge wells; imprecise or operator-dependent methods) and the need to control avoidable errors. 


\section{1) Questions of Scale}

A sampling plan designed to collect representative samples must take into account the potential scale of changes in site conditions through space and time as well as the chemical associations and behavior of the parameters that are targeted for investigation. In subsurface systems, physical (i.e., aquifer) and chemical properties over time or space are not statistically independent. In fact, samples taken in close proximity (i.e., within distances of a few meters) or within short time periods (i.e., more frequently than monthly) are highly auto-correlated. This means that designs employing high-sampling frequency (e.g., monthly) or dense spatial monitoring designs run the risk of redundant data collection and misleading inferences regarding trends in values that aren't statistically valid. In practice, contaminant detection and assessment monitoring programs rarely suffer these over-sampling concerns. In corrective-action evaluation programs, it is also possible that too little data may be collected over space or time. In these cases, false interpretation of the spatial extent of contamination or underestimation of temporal concentration variability may result.

\section{2) Target Parameters}

Parameter selection in monitoring program design is most often dictated by the regulatory status of the site. However, background water quality constituents, purging indicator parameters, and contaminants, all represent targets for data collection programs. The tools and procedures used in these programs should be equally rigorous and applicable to all categories of data, since all may be needed to determine or support regulatory action.

\section{Sampling Point Design and Construction}

Detailed site characterization is central to all decision-making purposes and the basis for this characterization resides in identification of the geologic framework and major hydro-stratigraphic units. Fundamental data for sample point location include: subsurface lithology, head-differences and background geochemical conditions. Each sampling point has a proper use or uses which should be documented at a level which is appropriate for the program's data quality objectives. Individual sampling points may not always be able to fulfill multiple monitoring objectives (e.g., detection, assessment, corrective action).

\section{1) Compatibility with Monitoring Program and Data} Quality Objectives

Specifics of sampling point location and design will be dictated by the complexity of subsurface lithology and variability in contaminant and/or geochemical conditions. It should be noted that, regardless of the ground-water sampling approach, few sampling points (e.g., wells, drive-points, screened augers) have zones of influence in excess of a few feet. Therefore, the spatial frequency of sampling points should be carefully selected and designed.

\section{2) Flexibility of Sampling Point Design}

In most cases well-point diameters in excess of $17 / 8$ inches will permit the use of most types of submersible pumping devices for low-flow (minimal drawdown) sampling. It is suggested that short (e.g., less than $1.6 \mathrm{~m}$ ) screens be incorporated into the monitoring design where possible so that comparable results from one device to another might be expected. Short, of course, is relative to the degree of vertical water quality variability expected at a site.

\section{3) Equilibration of Sampling Point}

Time should be allowed for equilibration of the well or sampling point with the formation after installation. Placement of well or sampling points in the subsurface produces some disturbance of ambient conditions. Drilling techniques (e.g., auger, rotary, etc.) are generally considered to cause more disturbance than direct-push technologies. In either case, there may be a period (i.e., days to months) during which water quality near the point may be distinctly different from that in the formation. Proper development of the sampling point and adjacent formation to remove fines created during emplacement will shorten this water quality recovery period.

\section{Definition of Low-Flow Purging and Sampling}

It is generally accepted that water in the well casing is non-representative of the formation water and needs to be purged prior to collection of ground-water samples. However, the water in the screened interval may indeed be representative of the formation, depending upon well construction and site hydrogeology. Wells are purged to some extent for the following reasons: the presence of the air interface at the top of the water column resulting in an oxygen concentration gradient with depth, loss of volatiles up the water column, leaching from or sorption to the casing or filter pack, chemical changes due to clay seals or backfill, and surface infiltration.

Low-flow purging, whether using portable or dedicated systems, should be done using pump-intake located in the middle or slightly above the middle of the screened interval. Placement of the pump too close to the bottom of the well will cause increased entrainment of solids which have collected in the well over time. These particles are present as a result of well development, prior purging and sampling events, and natural colloidal transport and deposition. Therefore, placement of the pump in the middle or toward the top of the screened interval is suggested. Placement of the pump at the top of the water column for sampling is only recommended in unconfined aquifers, screened across the water table, where this is the desired sampling point. Low- 
flow purging has the advantage of minimizing mixing between the overlying stagnant casing water and water within the screened interval.

\section{A. Low-Flow Purging and Sampling}

Low-flow refers to the velocity with which water enters the pump intake and that is imparted to the formation pore water in the immediate vicinity of the well screen. It does not necessarily refer to the flow rate of water discharged at the surface which can be affected by flow regulators or restrictions. Water level drawdown provides the best indication of the stress imparted by a given flow-rate for a given hydrological situation. The objective is to pump in a manner that minimizes stress (drawdown) to the system to the extent practical taking into account established site sampling objectives. Typically, flow rates on the order of $0.1-0.5 \mathrm{~L} / \mathrm{min}$ are used, however this is dependent on site-specific hydrogeology. Some extremely coarse-textured formations have been successfully sampled in this manner at flow rates to $1 \mathrm{~L} / \mathrm{min}$. The effectiveness of using low-flow purging is intimately linked with proper screen location, screen length, and well construction and development techniques. The reestablishment of natural flow paths in both the vertical and horizontal directions is important for correct interpretation of the data. For high resolution sampling needs, screens less than $1 \mathrm{~m}$ should be used. Most of the need for purging has been found to be due to passing the sampling device through the overlying casing water which causes mixing of these stagnant waters and the dynamic waters within the screened interval. Additionally, there is disturbance to suspended sediment collected in the bottom of the casing and the displacement of water out into the formation immediately adjacent to the well screen. These disturbances and impacts can be avoided using dedicated sampling equipment, which precludes the need to insert the sampling device prior to purging and sampling.

Isolation of the screened interval water from the overlying stagnant casing water may be accomplished using low-flow minimal drawdown techniques. If the pump intake is located within the screened interval, most of the water pumped will be drawn in directly from the formation with little mixing of casing water or disturbance to the sampling zone. However, if the wells are not constructed and developed properly, zones other than those intended may be sampled. At some sites where geologic heterogeneities are sufficiently different within the screened interval, higher conductivity zones may be preferentially sampled. This is another reason to use shorter screened intervals, especially where high spatial resolution is a sampling objective.

\section{B. Water Quality Indicator Parameters}

It is recommended that water quality indicator parameters be used to determine purging needs prior to sample collection in each well. Stabilization of parameters such as $\mathrm{pH}$, specific conductance, dissolved oxygen, oxida- tion-reduction potential, temperature and turbidity should be used to determine when formation water is accessed during purging. In general, the order of stabilization is $\mathrm{pH}$, temperature, and specific conductance, followed by oxidationreduction potential, dissolved oxygen and turbidity. Temperature and $\mathrm{pH}$, while commonly used as purging indicators, are actually quite insensitive in distinguishing between formation water and stagnant casing water; nevertheless, these are important parameters for data interpretation purposes and should also be measured. Performance criteria for determination of stabilization should be based on water-level drawdown, pumping rate and equipment specifications for measuring indicator parameters. Instruments are available which utilize in-line flow cells to continuously measure the above parameters.

It is important to establish specific well stabilization criteria and then consistently follow the same methods thereafter, particularly with respect to drawdown, flow rate and sampling device. Generally, the time or purge volume required for parameter stabilization is independent of well depth or well volumes. Dependent variables are well diameter, sampling device, hydrogeochemistry, pump flow rate, and whether the devices are used in a portable or dedicated manner. If the sampling device is already in place (i.e., dedicated sampling systems), then the time and purge volume needed for stabilization is much shorter. Other advantages of dedicated equipment include less purge water for waste disposal, much less decontamination of equipment, less time spent in preparation of sampling as well as time in the field, and more consistency in the sampling approach which probably will translate into less variability in sampling results. The use of dedicated equipment is strongly recommended at wells which will undergo routine sampling over time.

If parameter stabilization criteria are too stringent then minor oscillations in indicator parameters may cause purging operations to become unnecessarily protracted. It should also be noted that turbidity is a very conservative parameter in terms of stabilization. Turbidity is always the last parameter to stabilize. Excessive purge times are invariably related to the establishment of too stringent turbidity stabilization criteria. It should be noted that natural turbidity levels in ground water may exceed 10 nephelometric turbidity units (NTU).

\section{Advantages and Disadvantages of Low-Flow (Minimum Drawdown) Purging} include:

In general, the advantages of low-flow purging

- samples which are representative of the mobile load of contaminants present (dissolved and colloid-associated);

- minimal disturbance of the sampling point thereby minimizing sampling artifacts;

- less operator variability, greater operator control; 
- reduced stress on the formation (minimal drawdown);

- less mixing of stagnant casing water with formation water;

- reduced need for filtration and, therefore, less time required for sampling;

- smaller purging volume which decreases waste disposal costs and sampling time;

- better sample consistency; reduced artificial sample variability.

Some disadvantages of low-flow purging are:

- higher initial capital costs,

- greater set-up time in the field,

- need to transport additional equipment to and from the site,

- increased training needs,

- resistance to change on the part of sampling practitioners,

- concern that new data will indicate a change in conditions and trigger an action.

\section{Low-Flow (Minimal Drawdown) Sampling Protocols}

The following ground-water sampling procedure has evolved over many years of experience in ground-water sampling for organic and inorganic compound determinations and as such summarizes the authors' (and others) experiences to date (Barcelona et al., 1984, 1994; Barcelona and Helfrich, 1986; Puls and Barcelona, 1989; Puls et. al. 1990, 1992; Puls and Powell, 1992; Puls and Paul, 1995). Highquality chemical data collection is essential in ground-water monitoring and site characterization. The primary limitations to the collection of representative ground-water samples include: mixing of the stagnant casing and fresh screen waters during insertion of the sampling device or groundwater level measurement device; disturbance and resuspension of settled solids at the bottom of the well when using high pumping rates or raising and lowering a pump or bailer; introduction of atmospheric gases or degassing from the water during sample handling and transfer, or inappropriate use of vacuum sampling device, etc.

\section{A. Sampling Recommendations}

Water samples should not be taken immediately following well development. Sufficient time should be allowed for the ground-water flow regime in the vicinity of the monitoring well to stabilize and to approach chemical equilibrium with the well construction materials. This lag time will depend on site conditions and methods of installation but often exceeds one week.

Well purging is nearly always necessary to obtain samples of water flowing through the geologic formations in the screened interval. Rather than using a general but arbitrary guideline of purging three casing volumes prior to sampling, it is recommended that an in-line water quality measurement device (e.g., flow-through cell) be used to establish the stabilization time for several parameters (e.g. , $\mathrm{pH}$, specific conductance, redox, dissolved oxygen, turbidity) on a well-specific basis. Data on pumping rate, drawdown, and volume required for parameter stabilization can be used as a guide for conducting subsequent sampling activities.

The following are recommendations to be considered before, during and after sampling:

- use low-flow rates $(<0.5 \mathrm{~L} / \mathrm{min})$, during both purging and sampling to maintain minimal drawdown in the well;

- maximize tubing wall thickness, minimize tubing length;

- place the sampling device intake at the desired sampling point;

- minimize disturbances of the stagnant water column above the screened interval during water level measurement and sampling device insertion;

- make proper adjustments to stabilize the flow rate as soon as possible

- monitor water quality indicators during purging;

- collect unfiltered samples to estimate contaminant loading and transport potential in the subsurface system.

\section{B. Equipment Calibration}

Prior to sampling, all sampling device and monitoring equipment should be calibrated according to manufacturer's recommendations and the site Quality Assurance Project Plan (QAPP) and Field Sampling Plan (FSP). Calibration of $\mathrm{pH}$ should be performed with at least two buffers which bracket the expected range. Dissolved oxygen calibration must be corrected for local barometric pressure readings and elevation.

\section{Water Level Measurement and Monitoring}

It is recommended that a device be used which will least disturb the water surface in the casing. Well depth should be obtained from the well logs. Measuring to the bottom of the well casing will only cause resuspension of settled solids from the formation and require longer purging times for turbidity equilibration. Measure well depth after sampling is completed. The water level measurement should be taken from a permanent reference point which is surveyed relative to ground elevation.

\section{Pump Type}

The use of low-flow (e.g., 0.1-0.5 L/min) pumps is suggested for purging and sampling all types of analytes. All pumps have some limitation and these should be investigated with respect to application at a particular site. Bailers are inappropriate devices for low-flow sampling. 


\section{1) General Considerations}

There are no unusual requirements for ground-water sampling devices when using low-flow, minimal drawdown techniques. The major concern is that the device give consistent results and minimal disturbance of the sample across a range of low flow rates (i.e., $<0.5 \mathrm{~L} / \mathrm{min}$ ). Clearly, pumping rates that cause minimal to no drawdown in one well could easily cause significant drawdown in another well finished in a less transmissive formation. In this sense, the pump should not cause undue pressure or temperature changes or physical disturbance on the water sample over a reasonable sampling range. Consistency in operation is critical to meet accuracy and precision goals.

\section{2) Advantages and Disadvantages of Sampling Devices}

A variety of sampling devices are available for lowflow (minimal drawdown) purging and sampling and include peristaltic pumps, bladder pumps, electrical submersible pumps, and gas-driven pumps. Devices which lend themselves to both dedication and consistent operation at definable low-flow rates are preferred. It is desirable that the pump be easily adjustable and operate reliably at these lower flow rates. The peristaltic pump is limited to shallow applications and can cause degassing resulting in alteration of $\mathrm{pH}$, alkalinity, and some volatiles loss. Gas-driven pumps should be of a type that does not allow the gas to be in direct contact with the sampled fluid.

Clearly, bailers and other grab type samplers are illsuited for low-flow sampling since they will cause repeated disturbance and mixing of stagnant water in the casing and the dynamic water in the screened interval. Similarly, the use of inertial lift foot-valve type samplers may cause too much disturbance at the point of sampling. Use of these devices also tends to introduce uncontrolled and unacceptable operator variability.

Summaries of advantages and disadvantages of various sampling devices are listed in Herzog et al. (1991), U. S. EPA (1992), Parker (1994) and Thurnblad (1994).

\section{E. Pump Installation}

Dedicated sampling devices (left in the well) capable of pumping and sampling are preferred over any other type of device. Any portable sampling device should be slowly and carefully lowered to the middle of the screened interval or slightly above the middle (e.g., 1-1.5 m below the top of a $3 \mathrm{~m}$ screen). This is to minimize excessive mixing of the stagnant water in the casing above the screen with the screened interval zone water, and to minimize resuspension of solids which will have collected at the bottom of the well. These two disturbance effects have been shown to directly affect the time required for purging. There also appears to be a direct correlation between size of portable sampling devices relative to the well bore and resulting purge volumes and times. The key is to minimize disturbance of water and solids in the well casing.

\section{F. Filtration}

Decisions to filter samples should be dictated by sampling objectives rather than as a fix for poor sampling practices, and field-filtering of certain constituents should not be the default. Consideration should be given as to what the application of field-filtration is trying to accomplish. For assessment of truly dissolved (as opposed to operationally dissolved [i.e., samples filtered with $0.45 \mu \mathrm{m}$ filters]) concentrations of major ions and trace metals, $0.1 \mu \mathrm{m}$ filters are recommended although $0.45 \mu \mathrm{m}$ filters are normally used for most regulatory programs. Alkalinity samples must also be filtered if significant particulate calcium carbonate is suspected, since this material is likely to impact alkalinity titration results (although filtration itself may alter the $\mathrm{CO}_{2}$ composition of the sample and, therefore, affect the results).

Although filtration may be appropriate, filtration of a sample may cause a number of unintended changes to occur (e.g. oxidation, aeration) possibly leading to filtration-induced artifacts during sample analysis and uncertainty in the results. Some of these unintended changes may be unavoidable but the factors leading to them must be recognized. Deleterious effects can be minimized by consistent application of certain filtration guidelines. Guidelines should address selection of filter type, media, pore size, etc. in order to identify and minimize potential sources of uncertainty when filtering samples.

In-line filtration is recommended because it provides better consistency through less sample handling, and minimizes sample exposure to the atmosphere. In-line filters are available in both disposable (barrel filters) and nondisposable (in-line filter holder, flat membrane filters) formats and various filter pore sizes $(0.1-5.0 \mu \mathrm{m})$. Disposable filter cartridges have the advantage of greater sediment handling capacity when compared to traditional membrane filters. Filters must be pre-rinsed following manufacturer's recommendations. If there are no recommendations for rinsing, pass through a minimum of $1 \mathrm{~L}$ of ground water following purging and prior to sampling. Once filtration has begun, a filter cake may develop as particles larger than the pore size accumulate on the filter membrane. The result is that the effective pore diameter of the membrane is reduced and particles smaller than the stated pore size are excluded from the filtrate. Possible corrective measures include prefiltering (with larger pore size filters), minimizing particle loads to begin with, and reducing sample volume.

\section{G. Monitoring of Water Level and Water Quality Indicator Parameters}

Check water level periodically to monitor drawdown in the well as a guide to flow rate adjustment. The goal is minimal drawdown $(<0.1 \mathrm{~m})$ during purging. This goal may be difficult to achieve under some circumstances due to geologic heterogeneities within the screened interval, and may require adjustment based on site-specific conditions and personal experience. In-line water quality indicator parameters should be continuously monitored during purging. The water quality 
indicator parameters monitored can include $\mathrm{pH}$, redox potential, conductivity, dissolved oxygen (DO) and turbidity. The last three parameters are often most sensitive. Pumping rate, drawdown, and the time or volume required to obtain stabilization of parameter readings can be used as a future guide to purge the well. Measurements should be taken every three to five minutes if the above suggested rates are used. Stabilization is achieved after all parameters have stabilized for three successive readings. In lieu of measuring all five parameters, a minimum subset would include $\mathrm{pH}$, conductivity, and turbidity or DO. Three successive readings should be within \pm 0.1 for $\mathrm{pH}, \pm 3 \%$ for conductivity, $\pm 10 \mathrm{mv}$ for redox potential, and $\pm 10 \%$ for turbidity and DO. Stabilized purge indicator parameter trends are generally obvious and follow either an exponential or asymptotic change to stable values during purging. Dissolved oxygen and turbidity usually require the longest time for stabilization. The above stabilization guidelines are provided for rough estimates based on experience.

\section{H. Sampling, Sample Containers, Preservation and Decontamination}

Upon parameter stabilization, sampling can be initiated. If an in-line device is used to monitor water quality parameters, it should be disconnected or bypassed during sample collection. Sampling flow rate may remain at established purge rate or may be adjusted slightly to minimize aeration, bubble formation, turbulent filling of sample bottles, or loss of volatiles due to extended residence time in tubing. Typically, flow rates less than $0.5 \mathrm{~L} / \mathrm{min}$ are appropriate. The same device should be used for sampling as was used for purging. Sampling should occur in a progression from least to most contaminated well, if this is known. Generally, volatile (e.g., solvents and fuel constituents) and gas sensitive (e.g., $\mathrm{Fe}^{2+}, \mathrm{CH}_{4}, \mathrm{H}_{2} \mathrm{~S} / \mathrm{HS}$, alkalinity) parameters should be sampled first. The sequence in which samples for most inorganic parameters are collected is immaterial unless filtered (dissolved) samples are desired. Filtering should be done last and in-line filters should be used as discussed above. During both well purging and sampling, proper protective clothing and equipment must be used based upon the type and level of contaminants present.

The appropriate sample container will be prepared in advance of actual sample collection for the analytes of interest and include sample preservative where necessary. Water samples should be collected directly into this container from the pump tubing.

Immediately after a sample bottle has been filled, it must be preserved as specified in the site (QAPP). Sample preservation requirements are based on the analyses being performed (use site QAPP, FSP, RCRA guidance document [U. S. EPA, 1992] or EPA SW-846 [U. S. EPA, 1982] ). It may be advisable to add preservatives to sample bottles in a controlled setting prior to entering the field in order to reduce the chances of improperly preserving sample bottles or introducing field contaminants into a sample bottle while adding the preservatives.

The preservatives should be transferred from the chemical bottle to the sample container using a disposable polyethylene pipet and the disposable pipet should be used only once and then discarded

After a sample container has been filled with ground water, a Teflon ${ }^{\mathrm{TM}}$ (or tin)-lined cap is screwed on tightly to prevent the container from leaking. A sample label is filled out as specified in the FSP. The samples should be stored inverted at $4^{\circ} \mathrm{C}$.

Specific decontamination protocols for sampling devices are dependent to some extent on the type of device used and the type of contaminants encountered. Refer to the site QAPP and FSP for specific requirements.

\section{Blanks}

The following blanks should be collected:

(1) field blank: one field blank should be collected from each source water (distilled/deionized water) used for sampling equipment decontamination or for assisting well development procedures.

(2) equipment blank: one equipment blank should be taken prior to the commencement of field work, from each set of sampling equipment to be used for that day. Refer to site QAPP or FSP for specific requirements.

(3) trip blank: a trip blank is required to accompany each volatile sample shipment. These blanks are prepared in the laboratory by filling a $40-\mathrm{mL}$ volatile organic analysis (VOA) bottle with distilled/deionized water.

\section{Low-Permeability Formations and Fractured Rock}

The overall sampling program goals or sampling objectives will drive how the sampling points are located, installed, and choice of sampling device. Likewise, sitespecific hydrogeologic factors will affect these decisions. Sites with very low permeability formations or fractures causing discrete flow channels may require a unique monitoring approach. Unlike water supply wells, wells installed for ground-water quality assessment and restoration programs are often installed in low water-yielding settings (e.g., clays, silts). Alternative types of sampling points and sampling methods are often needed in these types of environments, because low-permeability settings may require extremely lowflow purging $(<0.1 \mathrm{~L} / \mathrm{min})$ and may be technology-limited. Where devices are not readily available to pump at such low flow rates, the primary consideration is to avoid dewatering of 
the well screen. This may require repeated recovery of the water during purging while leaving the pump in place within the well screen.

Use of low-flow techniques may be impractical in these settings, depending upon the water recharge rates. The sampler and the end-user of data collected from such wells need to understand the limitations of the data collected i.e., a strong potential for underestimation of actual contaminant concentrations for volatile organics, potential false negatives for filtered metals and potential false positives for unfiltered metals. It is suggested that comparisons be made between samples recovered using low-flow purging techniques and samples recovered using passive sampling techniques (i.e., two sets of samples). Passive sample collection would essentially entail acquisition of the sample with no or very little purging using a dedicated sampling system installed within the screened interval or a passive sample collection device.

\section{A. Low-Permeability Formations $(<0.1 \mathrm{~L} / \mathrm{min}$ recharge)}

\section{Low-Flow Purging and Sampling with Pumps}

a. "portable or non-dedicated mode" - Lower the pump (one capable of pumping at $<0.1 \mathrm{~L} / \mathrm{min}$ ) to mid-screen or slightly above and set in place for minimum of 48 hours (to lessen purge volume requirements). After 48 hours, use procedures listed in Part IV above regarding monitoring water quality parameters for stabilization, etc., but do not dewater the screen. If excessive drawdown and slow recovery is a problem, then alternate approaches such as those listed below may be better.

b. "dedicated mode" - Set the pump as above at least a week prior to sampling; that is, operate in a dedicated pump mode. With this approach significant reductions in purge volume should be realized. Water quality parameters should stabilize quite rapidly due to less disturbance of the sampling zone.

\section{Passive Sample Collection}

Passive sampling collection requires insertion of the device into the screened interval for a sufficient time period to allow flow and sample equilibration before extraction for analysis. Conceptually, the extraction of water from low yielding formations seems more akin to the collection of water from the unsaturated zone and passive sampling techniques may be more appropriate in terms of obtaining "representative" samples. Satisfying usual sample volume requirements is typically a problem with this approach and some latitude will be needed on the part of regulatory entities to achieve sampling objectives

\section{B. Fractured Rock}

In fractured rock formations, a low-flow to zero purging approach using pumps in conjunction with packers to isolate the sampling zone in the borehole is suggested. Passive multi-layer sampling devices may also provide the most "representative" samples. It is imperative in these settings to identify flow paths or water-producing fractures prior to sampling using tools such as borehole flowmeters and/or other geophysical tools.

After identification of water-bearing fractures, install packer(s) and pump assembly for sample collection using low-flow sampling in "dedicated mode" or use a passive sampling device which can isolate the identified water-bearing fractures.

\section{Documentation}

The usual practices for documenting the sampling event should be used for low-flow purging and sampling techniques. This should include, at a minimum: information on the conduct of purging operations (flow-rate, drawdown, water-quality parameter values, volumes extracted and times for measurements), field instrument calibration data, water sampling forms and chain of custody forms. See Figures 2 and 3 and "Ground Water Sampling Workshop -- A Workshop Summary" (U. S. EPA, 1995) for example forms and other documentation suggestions and information. This information coupled with laboratory analytical data and validation data are needed to judge the "useability" of the sampling data.

\section{Notice}

The U.S. Environmental Protection Agency through its Office of Research and Development funded and managed the research described herein as part of its in-house research program and under Contract No. 68-C4-0031 to Dynamac Corporation. It has been subjected to the Agency's peer and administrative review and has been approved for publication as an EPA document. Mention of trade names or commercial products does not constitute endorsement or recommendation for use.

\section{References}

Backhus, D,A., J.N. Ryan, D.M. Groher, J.K. McFarlane, and P.M. Gschwend. 1993. Sampling Colloids and ColloidAssociated Contaminants in Ground Water. Ground Water, 31(3):466-479.

Barcelona, M.J., J.A. Helfrich, E.E. Garske, and J.P. Gibb. 1984. A laboratory evaluation of groundwater sampling mechanisms. Ground Water Monitoring Review, 4(2):32-41. 
Barcelona, M.J. and J.A. Helfrich. 1986. Well construction and purging effects on ground-water samples. Environ. Sci. Technol., 20(11):1179-1184.

Barcelona, M.J., H.A. Wehrmann, and M.D. Varljen. 1994 Reproducible well purging procedures and VOC stabilization criteria for ground-water sampling. Ground Water, 32(1):1222.

Buddemeier, R.W. and J.R. Hunt. 1988. Transport of Colloidal Contaminants in Ground Water: Radionuclide Migration at the Nevada Test Site. Applied Geochemistry, 3: 535-548.

Danielsson, L.G. 1982. On the Use of Filters for Distinguishing Between Dissolved and Particulate Fractions in Natural Waters. Water Research, 16:179.

Enfield, C.G. and G. Bengtsson. 1988. Macromolecular Transport of Hydrophobic Contaminants in Aqueous Environments. Ground Water, 26(1): 64-70.

Gschwend, P.M. and M.D. Reynolds. 1987. Monodisperse Ferrous Phosphate Colloids in an Anoxic Groundwater Plume, $J$. of Contaminant Hydrol., 1: 309-327.

Herzog, B., J. Pennino, and G. Nielsen. 1991. Ground-Water Sampling. In Practical Handbook of Ground-Water Monitoring (D.M. Nielsen, ed.). Lewis Publ., Chelsea, MI, pp. 449 499 .

Horowitz, A.J., K.A. Elrick, and M.R. Colberg. 1992. The effect of membrane filtration artifacts on dissolved trace element concentrations. Water Res., 26(6):753-763.

Laxen, D.P.H. and I.M. Chandler. 1982. Comparison of Filtration Techniques for Size Distribution in Freshwaters. Analytical Chemistry, 54(8):1350.

McCarthy, J.F. and J.M. Zachara. 1989. Subsurface Transport of Contaminants, Environ. Sci. Technol., 5(23):496-502.

McCarthy, J.F. and C. Degueldre. 1993. Sampling and Characterization of Colloids and Ground Water for Studying Their Role in Contaminant Transport. In: Environmental Particles (J. Buffle and H.P. van Leeuwen, eds.), Lewis Publ., Chelsea, MI, pp. 247-315

Parker, L.V. 1994. The Effects of Ground Water Sampling Devices on Water Quality: A Literature Review. Ground Water Monitoring and Remediation, 14(2):130-141.

Penrose, W.R., W.L. Polzer, E.H. Essington, D.M. Nelson, and K.A. Orlandini. 1990. Mobility of Plutonium and Americium through a Shallow Aquifer in a Semiarid Region, Environ. Sci. Technol., 24:228-234.

Puls, R.W. and M.J. Barcelona. 1989. Filtration of Ground Water Samples for Metals Analyses. Hazardous Waste and Hazardous Materials, 6(4):385-393.
Puls, R.W., J.H. Eychaner, and R.M. Powell. 1990. ColloidalFacilitated Transport of Inorganic Contaminants in Ground Water: Part I. Sampling Considerations. EPA600/M-90/023, NTIS PB 91-168419.

Puls, R.W. 1990. Colloidal Considerations in Groundwater Sampling and Contaminant Transport Predictions. Nuclear Safety, 31(1):58-65.

Puls, R.W. and R.M. Powell. 1992. Acquisition of Representative Ground Water Quality Samples for Metals. Ground Water Monitoring Review, 12(3):167-176.

Puls, R.W., D.A. Clark, B.Bledsoe, R.M. Powell, and C.J. Paul. 1992. Metals in Ground Water: Sampling Artifacts and Reproducibility. Hazardous Waste and Hazardous Materials $9(2): 149-162$

Puls, R.W. and C.J. Paul. 1995. Low-Flow Purging and Sampling of Ground-Water Monitoring Wells with Dedicated Systems. Ground Water Monitoring and Remediation, 15(1):116-123.

Ryan, J.N. and P.M. Gschwend. 1990. Colloid Mobilization in Two Atlantic Coastal Plain Aquifers. Water Resour. Res., 26: 307-322.

Thurnblad, T. 1994. Ground Water Sampling Guidance: Development of Sampling Plans, Sampling Protocols, and Sampling Reports. Minnesota Pollution Control Agency.

U. S. EPA. 1992. RCRA Ground-Water Monitoring: Draft Technical Guidance. Office of Solid Waste, Washington, DC EPA/530/R-93/001, NTIS PB 93-139350.

U. S. EPA. 1995. Ground Water Sampling Workshop -- A Workshop Summary, Dallas, TX, November 30 - December 2 , 1993. EPA/600/R-94/205, NTIS PB 95-193249, 126 pp.

U. S. EPA. 1982. Test Methods for Evaluating Solid Waste, Physical/Chemical Methods, EPA SW-846. Office of Solid Waste and Emergency Response, Washington, D.C. 
Figure 2. Ground Water Sampling Log

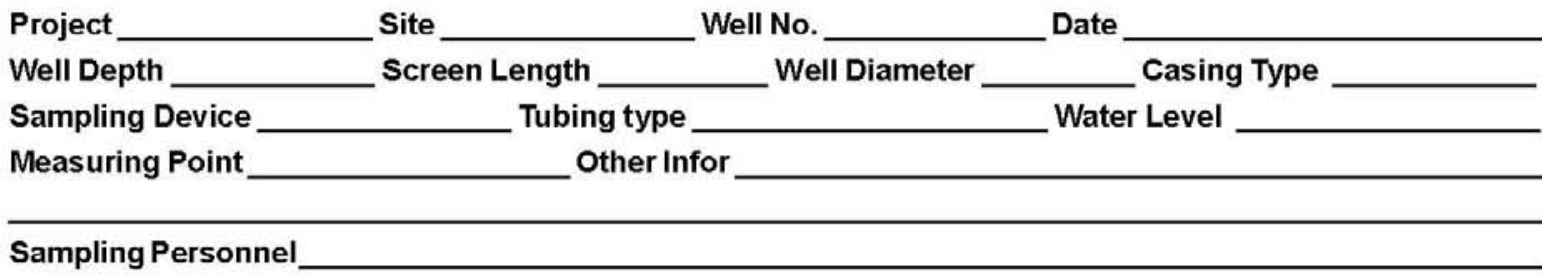

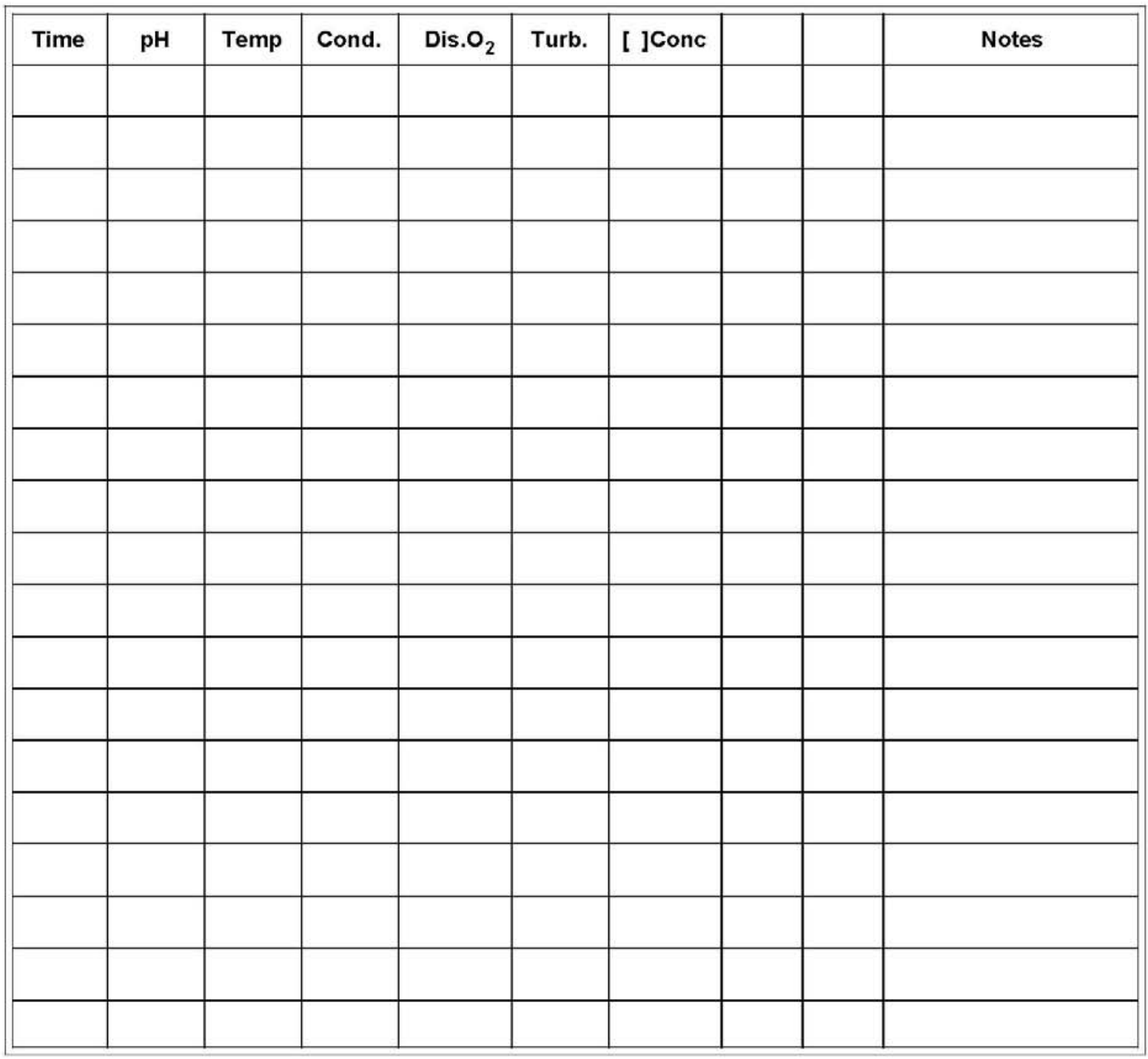

Type of Samples Collected

Information: 2 in $=617 \mathrm{ml} / \mathrm{ft}, 4 \mathrm{in}=2470 \mathrm{ml} / \mathrm{ft}: \mathrm{Vol}_{\mathrm{cyl}}=\pi \mathrm{r}^{2} \mathrm{~h}, \mathrm{Vol}_{\text {sphere }}=4 / 3 \pi \mathrm{r}^{3}$ 
Figure 3. Ground Water Sampling Log (with automatic data logging for most water quality parameters)

Project

Well Depth

Sampling Device

Measuring Point
Site

Screen Length

Tubing type Other Infor
Well No. Well Diameter

Date Casing Type Water Level

\section{Sampling Personnel}

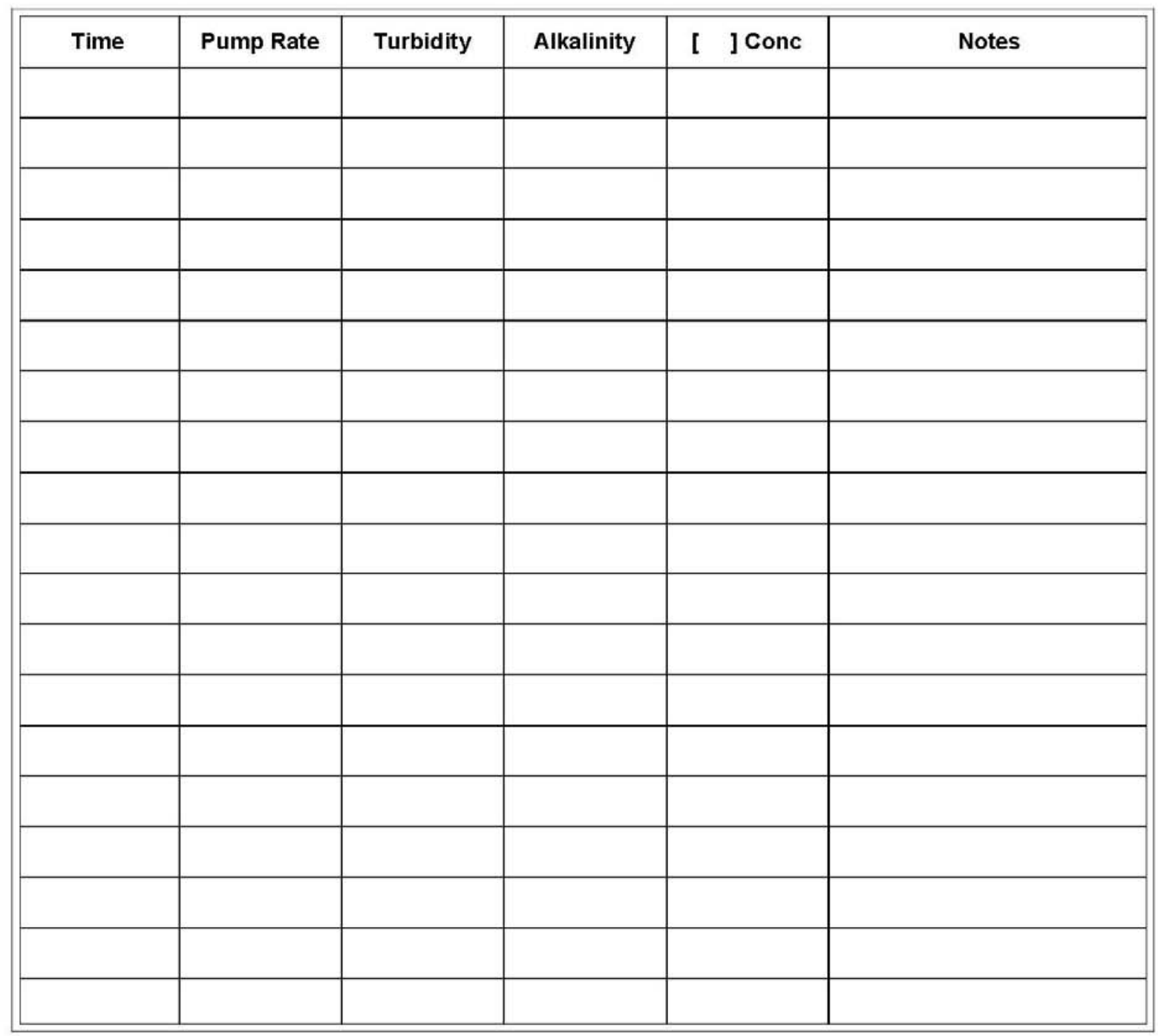

Type of Samples Collected

Information: 2 in $=617 \mathrm{ml} / \mathrm{ft}, 4$ in $=2470 \mathrm{ml} / \mathrm{ft}: V_{\text {oyl }}=\pi \mathrm{r}^{2} \mathrm{~h}, \mathrm{Vol}_{\text {sphere }}=4 / 3 \pi \mathrm{r}^{3}$ 


\section{Appendix B:}

Sequence of Sampling Activities at Centralia, Kansas, in March 2008 
TABLE B.1 Sequence of sampling activities at Centralia in March 2008.

\begin{tabular}{|c|c|c|c|c|c|c|c|c|}
\hline $\begin{array}{l}\text { Sample } \\
\text { Date }\end{array}$ & Time & Location & Sample & $\begin{array}{l}\text { Sample } \\
\text { Medium }\end{array}$ & Type $^{\mathrm{a}}$ & $\begin{array}{l}\text { Depth } \\
\text { (ft TOC) }\end{array}$ & $\begin{array}{l}\text { Chain of } \\
\text { Custody } \\
\text { No. }\end{array}$ & Sample Description \\
\hline 03/12/08 & 10:07 & MW02 & CNMW02-W-26000 & Water & MW & $49.5-59.5$ & 6078 & $\begin{array}{l}\text { Depth to water from TOC }=21.85 \mathrm{ft} \text {. Depth of } 4 \text {-in. well from } \\
\text { TOC }=59.50 \mathrm{ft} \text {. Sample collected by using low-flow } \\
\text { bladder pump after purging of } 3.05 \mathrm{~L} \text {. Purge water had } \\
\text { greenish color and had an odor. }\end{array}$ \\
\hline 03/12/08 & 12:06 & MW03 & CNMW03-W-26001 & Water & MW & $50.5-60.5$ & 6078 & $\begin{array}{l}\text { Depth to water from TOC }=21.22 \mathrm{ft} \text {. Depth of } 4 \text {-in. well from } \\
\text { TOC }=60.50 \mathrm{ft} \text {. Sample collected by using low-flow } \\
\text { bladder pump after purging of } 3.51 \mathrm{~L} \text {. Purge water clear. }\end{array}$ \\
\hline 03/12/08 & $12: 07$ & MW03 & CNMW03DUP-W-26021 & Water & MW & $50.5-60.5$ & 6078 & Replicate of sample CNMW03-W-26001. \\
\hline 03/12/08 & $14: 09$ & SB07R & CNSB07R-W-26003 & Water & $\mathrm{CPT/P}$ & $45-60$ & 6078 & $\begin{array}{l}\text { Depth to water from TOC }=18.23 \mathrm{ft} \text {. Depth of } 2 \text {-in. well from } \\
\text { TOC }=60 \mathrm{ft} \text {. Sample collected by using low-flow bladder } \\
\text { pump after purging of } 2.26 \mathrm{~L} \text {. Purge water clear. }\end{array}$ \\
\hline 03/12/08 & $14: 32$ & QC & CNQCIR-W-26017 & Water & $\mathrm{RI}$ & - & 6078 & $\begin{array}{l}\text { Rinsate of decontaminated bladder pump after collection of } \\
\text { sample CNSB07R-W-26003. }\end{array}$ \\
\hline 03/12/08 & $15: 51$ & SB08 & CNSB08-W-26004 & Water & CРT/P & $52-62$ & 6078 & $\begin{array}{l}\text { Depth to water from TOC }=19.24 \mathrm{ft} \text {. Depth of } 1 \text {-in. well from } \\
\text { TOC }=59.86 \mathrm{ft} \text {. Sample collected by using low-flow } \\
\text { bladder pump after purging of } 1.92 \mathrm{~L} \text {. Purge water clear. }\end{array}$ \\
\hline 03/12/08 & $17: 14$ & SB04 & CNSB04-W-26002 & Water & СРТ/P & $51-61$ & 6078 & $\begin{array}{l}\text { Depth to water from TOC }=22.34 \mathrm{ft} \text {. Depth of } 1 \text {-in. well from } \\
\text { TOC }=59.41 \mathrm{ft} \text {. Sample collected by using low-flow } \\
\text { bladder pump after purging of } 3.21 \mathrm{~L} \text {. Purge water clear. }\end{array}$ \\
\hline 03/13/08 & $14: 45$ & QC & CNQCTB-W-26014 & Water & TB & - & 6080 & $\begin{array}{l}\text { Trip blank sent to the AGEM Laboratory for organic } \\
\text { analyses with water samples listed on COCs } 6078 \text { and } \\
6080 \text { and to Envirosystems, Inc., for verification organic } \\
\text { analysis with water samples listed on COCs } 6079 \text { and } \\
6081 .\end{array}$ \\
\hline 03/19/08 & 9:13 & MW01 & CNMW01-W-26023 & Water & MW & $54.5-64.5$ & 6083 & $\begin{array}{l}\text { Depth to water from TOC }=11.89 \mathrm{ft} \text {. Depth of } 4 \text {-in. well from } \\
\text { TOC }=69.55 \mathrm{ft} \text {. Sample collected by using low-flow } \\
\text { bladder pump after purging of } 4.31 \mathrm{~L} \text {. Purge water clear, } \\
\text { no odor. }\end{array}$ \\
\hline 03/19/08 & $9: 47$ & QC & CNQCIR-W-26034 & Water & RI & - & 6083 & $\begin{array}{l}\text { Rinsate of decontaminated bladder pump after collection of } \\
\text { sample CNMW01-W-26023. }\end{array}$ \\
\hline 03/19/08 & $11: 46$ & MW04 & CNMW04-W-26024 & Water & MW & $37.5-47.5$ & 6083 & $\begin{array}{l}\text { Depth to water from TOC }=24.23 \mathrm{ft} \text {. Depth of } 4 \text {-in. well from } \\
\text { TOC }=49.25 \mathrm{ft} \text {. Sample collected by using low-flow } \\
\text { bladder pump after purging of } 3.72 \mathrm{~L} \text {. }\end{array}$ \\
\hline 03/19/08 & $11: 47$ & MW04 & CNMW04DUP-W-26036 & Water & MW & $37.5-47.5$ & 6083 & Replicate of sample CNMW04-W-26024. \\
\hline
\end{tabular}


TABLE B.1 (Cont.)

\begin{tabular}{|c|c|c|c|c|c|c|c|c|}
\hline $\begin{array}{l}\text { Sample } \\
\text { Date }\end{array}$ & Time & Location & Sample & $\begin{array}{l}\text { Sample } \\
\text { Medium }\end{array}$ & Type $^{a}$ & $\begin{array}{l}\text { Depth } \\
\text { (ft TOC) }\end{array}$ & $\begin{array}{l}\text { Chain of } \\
\text { Custody } \\
\text { No. }\end{array}$ & Sample Description \\
\hline 03/19/08 & $13: 56$ & MW05 & CNMW05-W-26025 & Water & MW & $34.5-44.5$ & 6083 & $\begin{array}{l}\text { Depth to water from TOC }=7.32 \mathrm{ft} \text {. Depth of } 4 \text {-in. well from } \\
\text { TOC }=47.58 \mathrm{ft} \text {. Sample collected by using low-flow } \\
\text { bladder pump after purging of } 4.25 \mathrm{~L} \text {. }\end{array}$ \\
\hline 03/19/08 & $15: 30$ & MW06 & CNMW06-W-26026 & Water & MW & $46.5-56.5$ & 6083 & $\begin{array}{l}\text { Depth to water from TOC }=34.70 \mathrm{ft} \text {. Depth of } 4 \text {-in. well from } \\
\text { TOC }=60.03 \mathrm{ft} \text {. Sample collected by using low-flow } \\
\text { bladder pump after purging of } 2.12 \mathrm{~L} \text {. Purge water was } \\
\text { tan. }\end{array}$ \\
\hline 03/19/08 & $15: 31$ & MW06 & CNMW06DUP-W-26037 & Water & MW & $46.5-56.5$ & 6083 & Replicate of sample CNMW06-W-26026. \\
\hline 03/19/08 & $16: 57$ & $\mathrm{QC}$ & CNQCTB-W-26035 & Water & TB & - & 6083 & $\begin{array}{l}\text { Trip blank sent to the AGEM Laboratory for organic } \\
\text { analyses with water samples listed on COC } 6083 \text { and to } \\
\text { Envirosystems, Inc., for verification organic analysis with } \\
\text { water samples listed on COC } 6084 \text {. }\end{array}$ \\
\hline 03/19/08 & $18: 22$ & MW07 & CNMW07-W-26027 & Water & MW & $45-55$ & 6085 & $\begin{array}{l}\text { Depth to water from TOC }=28.32 \mathrm{ft} \text {. Depth of } 2 \text {-in. well from } \\
\text { TOC }=58.50 \mathrm{ft} \text {. Sample collected by using low-flow } \\
\text { bladder pump after purging of } 2.5 \mathrm{~L} \text {. Purge water cloudy. }\end{array}$ \\
\hline 03/20/08 & $8: 46$ & MW10 & CNMW10-W-26030 & Water & MW & $30-45$ & 6085 & $\begin{array}{l}\text { Depth to water from TOC }=20.90 \mathrm{ft} \text {. Depth of } 2 \text {-in. well from } \\
\text { TOC }=47.73 \mathrm{ft} \text {. Sample collected by using low-flow } \\
\text { bladder pump after purging of } 4.0 \mathrm{~L} \text {. }\end{array}$ \\
\hline 03/20/08 & $9: 44$ & SB09 & CNSB09-W-26033 & Water & СРТ/P & $32-42$ & 6085 & $\begin{array}{l}\text { Depth to water from TOC }=2.90 \mathrm{ft} \text {. Depth of } 1 \text {-in. well from } \\
\text { TOC }=35.50 \mathrm{ft} \text {. Sample collected by using low-flow } \\
\text { bladder pump after purging of } 2.36 \mathrm{~L} \text {. Observation: Well } \\
\text { casing seems to be broken at } 3.9 \mathrm{ft} \text { below grade. }\end{array}$ \\
\hline 03/20/08 & 10:12 & MW08 & CNMW08-W-26028 & Water & MW & $38-53$ & 6085 & $\begin{array}{l}\text { Depth to water from TOC }=18.85 \mathrm{ft} \text {. Depth of } 2 \text {-in. well from } \\
\text { TOC }=57.15 \mathrm{ft} \text {. Sample collected by using low-flow } \\
\text { bladder pump after purging of } 4.1 \mathrm{~L} \text {. }\end{array}$ \\
\hline 03/20/08 & $11: 40$ & MW09 & CNMW09-W-26029 & Water & MW & $25-35$ & 6085 & $\begin{array}{l}\text { Depth to water from TOC }=0 \mathrm{ft} \text {. Depth of } 2 \text {-in. well from } \\
\text { TOC }=39.15 \mathrm{ft} \text {. Sample collected by using low-flow } \\
\text { bladder pump after purging of } 9 \mathrm{~L} \text {. Water flowed out of } \\
\text { casing when the plug was removed. }\end{array}$ \\
\hline 03/20/08 & $13: 23$ & SB01 & CNSB01-W-26031 & Water & СРТ/P & $40-50$ & 6085 & $\begin{array}{l}\text { Depth to water from TOC }=15.87 \mathrm{ft} \text {. Depth of } 1 \text {-in. well from } \\
\text { TOC }=48.90 \mathrm{ft} \text {. Sample collected by using low-flow } \\
\text { bladder pump after purging of } 5.4 \mathrm{~L} \text {. }\end{array}$ \\
\hline 03/20/08 & $14: 50$ & SB05 & CNSB05-W-26032 & Water & $\mathrm{CPT/P}$ & $32-42$ & 6085 & $\begin{array}{l}\text { Depth to water from TOC }=7.43 \mathrm{ft} \text {. Depth of } 1 \text {-in. well from } \\
\text { TOC }=41.02 \mathrm{ft} \text {. Sample collected by using Waterra pump } \\
\text { tubing as bailer after purging of } 10 \mathrm{~L} \text {. Observation: Well } \\
\text { casing seems to be broken at } 2 \mathrm{ft} 3 \mathrm{in} \text {. below grade. }\end{array}$ \\
\hline
\end{tabular}
casing seems to be broken at $2 \mathrm{ft} 3$ in. below grade. 
TABLE B.1 (Cont.)

\begin{tabular}{|c|c|c|c|c|c|c|c|c|}
\hline $\begin{array}{c}\text { Sample } \\
\text { Date }\end{array}$ & Time & Location & Sample & $\begin{array}{l}\text { Sample } \\
\text { Medium }\end{array}$ & Type $^{a}$ & $\begin{array}{c}\text { Depth } \\
\text { (ft TOC) }\end{array}$ & $\begin{array}{c}\text { Chain of } \\
\text { Custody } \\
\text { No. }\end{array}$ & Sample Description \\
\hline 03/20/08 & $14: 55$ & QC & CNQCTB-W-26038 & Water & TB & - & 6085 & $\begin{array}{l}\text { Trip blank sent to the AGEM Laboratory for organic } \\
\text { analyses with water samples listed on COC } 6085 \text {. }\end{array}$ \\
\hline
\end{tabular}

Sample types: CPT/P, cone penetrometer piezometer; RI, rinsate; MW, monitoring well; TB, trip blank. 


\section{Appendix C:}

Data Summary for Verification VOCs analyses by Envirosystems, Inc. 


\section{ENVIROSYSTEMS, INC.}

9200 Rumsey Road - Suite B102 - Columbia, Maryland 21045-1934

Phone (410) 964-0330 - Fax (410) 740-9306

Email: info@envsystems.com •Webpage: www.envsystems.com/envsys

April 17, 2008

Jorge S. Alvarado, PH. D

Argonne National Laboratory

Environmental Research Division

Applied Geosciences and Environmental

Management Section

9700 South Cass Avenue, ER-203

Argonne, Illinois 60439

RE: Report \#080158

Dear Jorge,

Enclosed is the Analytical Data Package for the samples received on March 14, 2008 for volatile organics analysis by USEPA SW846 method 8260B/CLP SOW OLM04.3 protocols.

Please do not hesitate to call if you have any questions, comments, or require additional information.

Sincerely,

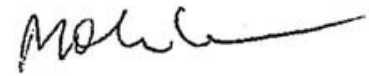

Mohan Khare Ph.D.

President/CEO

Enclosure (1)

$\mathrm{MK} / \mathrm{ncc}$ 


\section{SDG NARRATIVE VOLATILE ORGANICS (VOC)}

Envirosystems, Inc.

Contract: N/A

Client: Argonne National Laboratory

Case: N/A

SDG: ARG0080308

1. SAMPLE RECIEPT

Date received: 03-14-2008

Cooler Temperature: 2

\section{Sample Summary}

\begin{tabular}{|c|c|c|c|}
\hline Client ID & Laboratory ID & Matrix & pH \\
\hline CNMW03-W-26001 & $0080308-01$ & WATER & 2 \\
\hline CNPMP7-W-26011 & $0080308-02$ & WATER & 2 \\
\hline CNPMP3-W-26007 & $0080308-03$ & WATER & 2 \\
\hline CNQCTB-W-26014 & $0080308-04$ & WATER & 2 \\
\hline
\end{tabular}

\section{HOLDING TIMES}

3.

A. Sample Preparation: All holding times were met.

B. Sample Analysis: Sample analysis proceeded normally.

4. METHODS

5.

The samples were analyzed and reported by using method SW-846 $8260 \mathrm{~B}$ and USEPA CLP SOW OLM04.3 for target compound list.

\section{INSTRUMENT AND CHROMATOGRAPHIC CONDITIONS}

A Hewlett Packard 6890 gas chromatograph equipped with a Hewlet Packard 5975 MSD was used for sample analysis. The capillary column used was a Restek $20 \mathrm{~m}$ by $0.18 \mathrm{~mm}$ ID by $1.0 \mu \mathrm{m}$ film thickness (Restek Cat. \# RTX-624). The trap used with the sample concentrator is an Ol Analytical Trap \#10,30cm packed with Tenax/silica gel/cms (PN\#228122).

\section{PREPARATION}

The submitted samples were prepared and analyzed using method SW-846 8260B.

8. ANALYSIS

A. Calibration:

\section{Initial calibration}

All acceptance criteria as stipulated by SW $-8468260 \mathrm{~b}$ were met for all SPCC's and CCC's. All target compounds met the required percent RSD.

II. Blanks:

All acceptance criteria were met.

\section{Surrogates:}

All acceptance criteria were met except sample CNPMP3-W-26007 \& CNPMP3-W26007DL each had one surrogate slightly lower than QC limit.

B. Spikes:

1. Laboratory Control Spikes (LCS) 


\section{SDG NARRATIVE VOLATILE ORGANICS (VOC)}

LCS sample was not analyzed with this batch of samples.

\section{Matrix Spike/Matrix Spike Duplicate (MS/MSD)}

MS/MSD were not performed for this batch but shared with work order

0080313.performed for sample CNMW04-W-26024. All QC criteria were met.

\section{Internal Standards:}

All acceptance criteria were met.

\section{Samples}

Sample analysis proceeded normally. Sample CNPMP3-W-26007 was reanalyzed diluted to bring the compound concentration within QC limits of the calibration.

I certify that this Sample Data Package is in compliance with the terms and conditions of the contract, both technically and for completeness, for other than the conditions detailed above. Release of the data contained in the hard copy Sample Data Package and in the Electronic Data Deliverables has been authorized by the laboratory manager or the manager's designee, as verified by the following signatures.
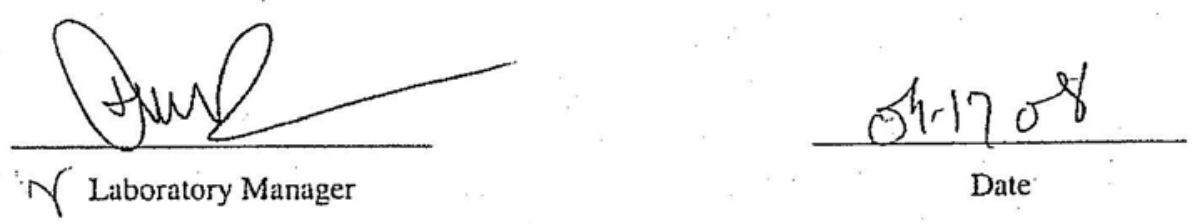


\section{Chain Of Custody}




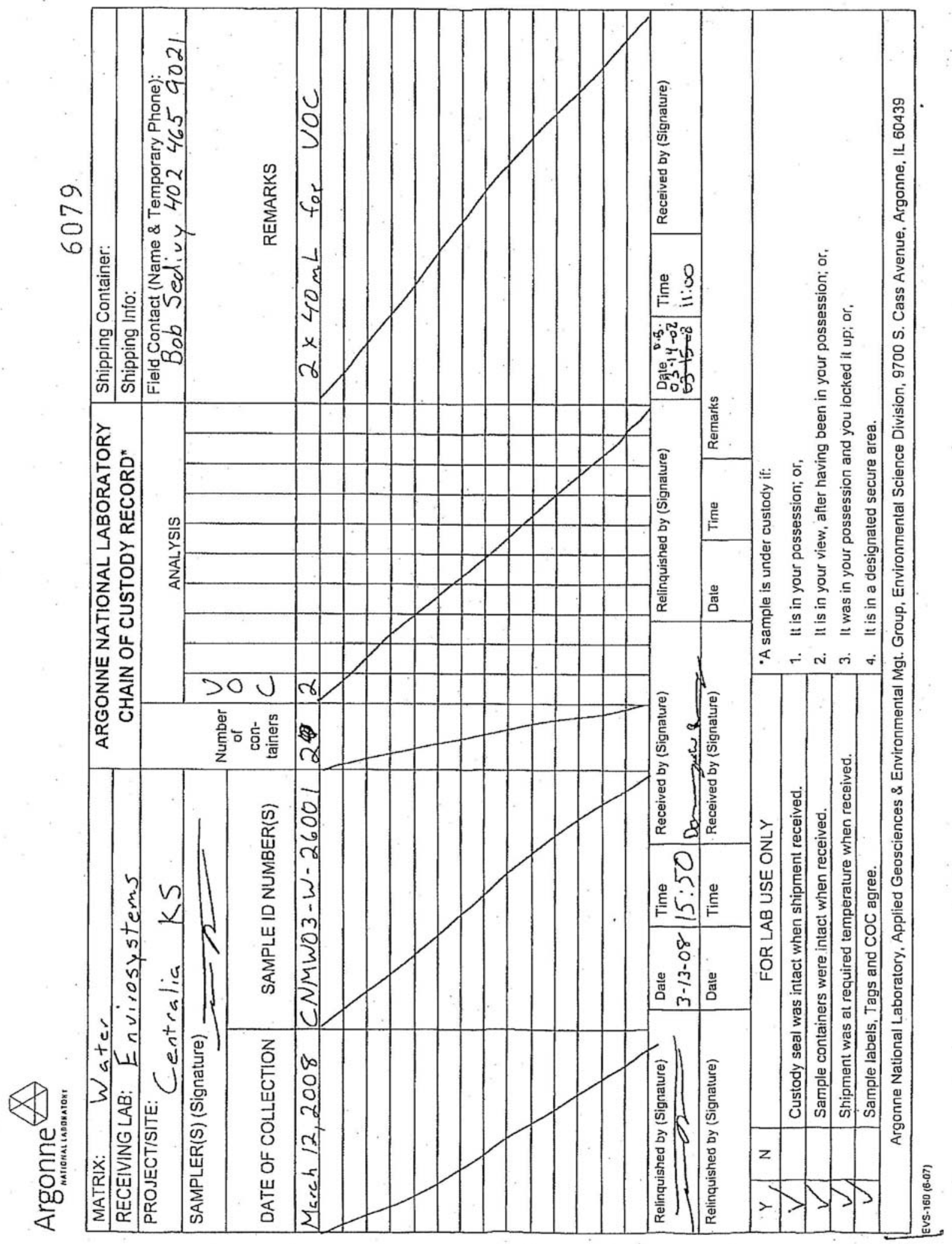




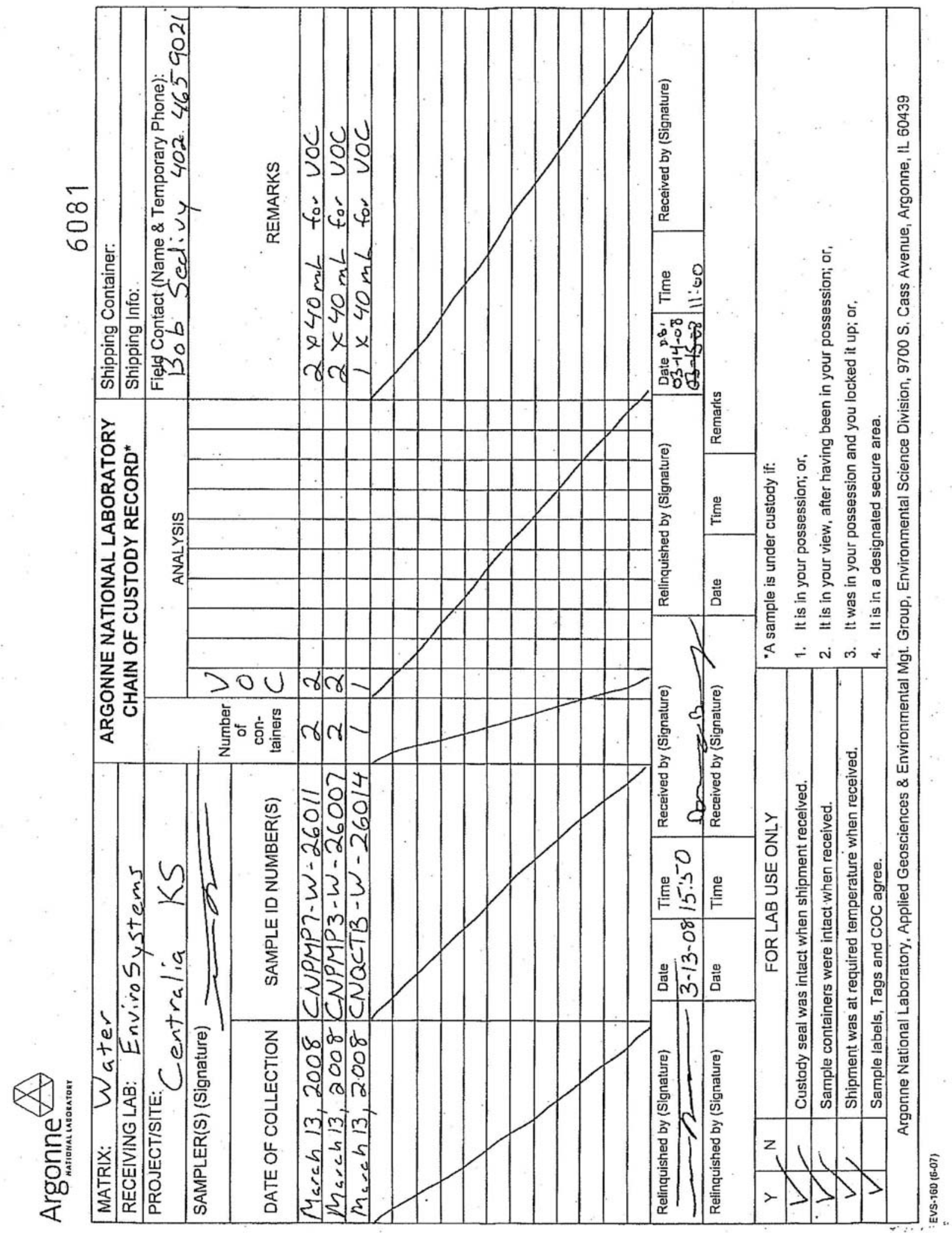


FORM 1

VOLATILE ORGANICS ANALYSIS DATA SHEET

Iab Name: ENVIROSYSTEMS, INC.

Lab Code: ENvSYS Case No. :

Matrix: (soil/water) WATER

Sample wt/vol:

$5.000(\mathrm{~g} / \mathrm{mL}) \mathrm{ML}$

Level: (low/med) LOW

․․․ Moisture: not dec.

GC Column: RTX-624 ID: 0.18 (mm)

Soil Extract Volume:

(uL)
Contract: N/A

SAS NO.: N/A
ARGONNE SAMPLE NO.

CNMW03-W-26001
SDG NO.: NA
Lab Sample ID: 0080308-01

Lab File ID: F000444

Date Received: 03/14/08

Date Analyzed: 03/14/08

Dilution Factor: 1.0

Soil Aliquot Volume: (UL)

CAS NO.

COMPOUND

CONCENTRATION UNITS:

(ug/L or $\mathrm{ug} / \mathrm{Kg}$ ) UG/L

Q

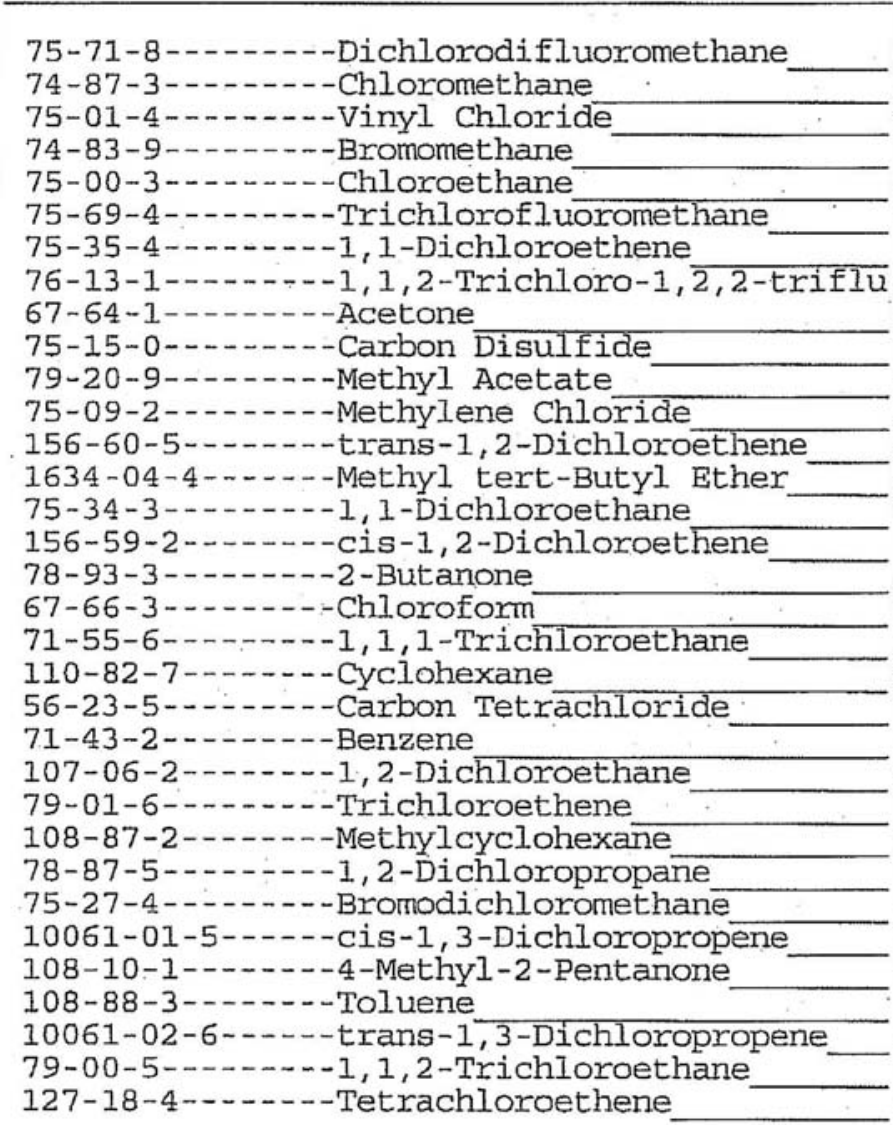

FORM I VOA

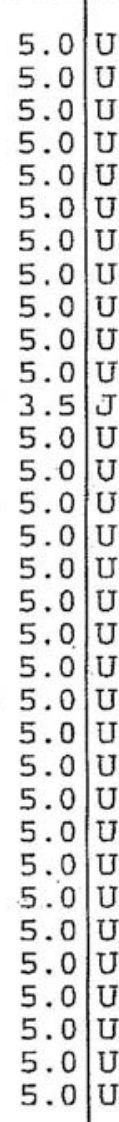


FORM 1

\section{VOLATILE ORGANICS ANALYSIS DATA SHEET}

Lab Name: ENVIROSYSTEMS, INC.

Lab Code: ENVSYS Case No.:

Matrix: (soil/water) WATER

Sample wt/vol:

$5.000(\mathrm{~g} / \mathrm{mL}) \mathrm{ML}$

Level: (low/med) LOW

\% Moisture: not dec.

GC Column: RTX-624 ID: 0.18 (mm)

Soil Extract Volume: (uI)
Contract: N/A

SAS NO: : N/A
ARGONNE SAMPLE NO.

CNMW03-W-26001

Lab Sample ID: 0080308-01

Lab File ID: F000444

Date Received: $03 / 14 / 08$

Date Analyzed: 03/14/08

Dilution Factor: 1.0

Soil Aliquot Volume: (uL) CONCENTRATION UNITS:

CAS NO. COMPOUND (ug/I or $\mathrm{ug} / \mathrm{Kg}$ ) UG/L

Q

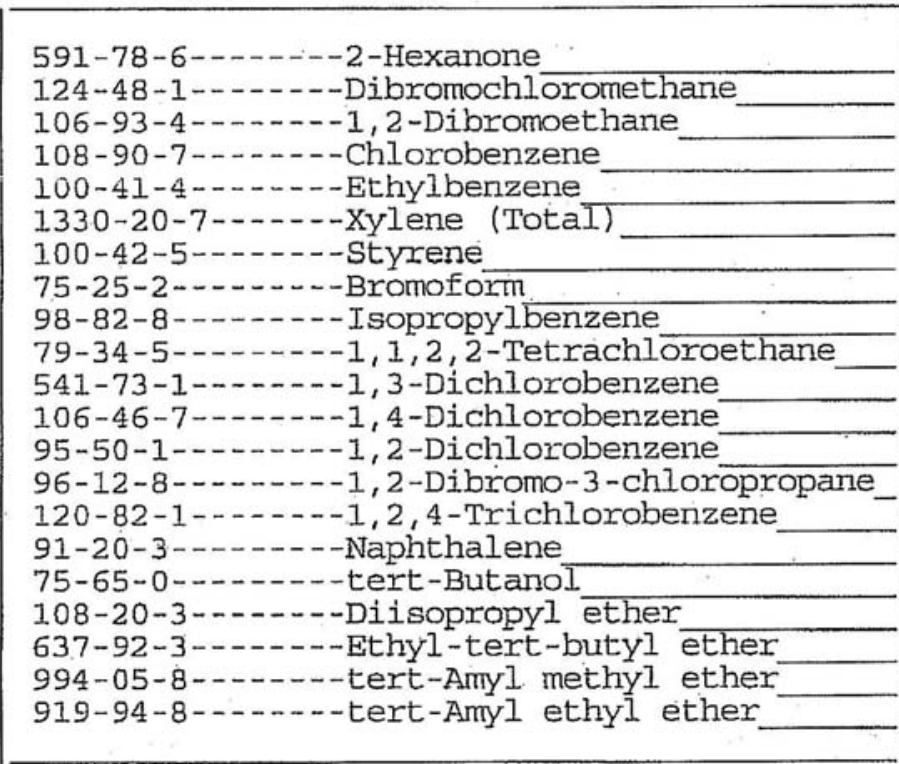

$5.0 \mathrm{U}$

$5.0 \mathrm{U}$

$5.0 \mathrm{U}$

$5.0 \mathrm{U}$

$5.0 \mathrm{U}$

$5.0 \mathrm{U}$

$5.0 \mathrm{U}$

$5.0 \mathrm{U}$

$5.0 \mathrm{U}$

$5.0 \mathrm{U}$

$5.0 \mathrm{U}$

$5.0 \mathrm{U}$

$5.0 \mathrm{U}$

$5.0 \mathrm{U}$

$5.0 \mathrm{U}$

$10 \mathrm{U}$

$5.0 \mathrm{U}$

$10 \mathrm{U}$ 
FORM 1 VOLATILE ORGANICS ANALYSIS DATA SHEET
ARGONNE SAMPLE NO.

CNOCTB-W-26014
Lab Name: ENVIROSYSTEMS, INC.

Lab Code: ENVSYS Case No.:

Matrix: (soil/water) WATER

Sample wt/vol:

$5.000(\mathrm{~g} / \mathrm{mL}) \mathrm{ML}$

Level: (low/med) LOW

\% Moisture: not dec.

GC Column: RTX-624 ID: 0.18 (mm)

Soil Extract Volume: (UI)
Contract: N/A

SAS NO.: N/A
SDG No.: NA

Lab Sample ID: 0080308-04

Lab File ID: F000446

Date Received: 03/14/08

Date Analyzed: 03/14/08

Dilution Factor: 1.0

Soil AIiquot Volume: (UIL)

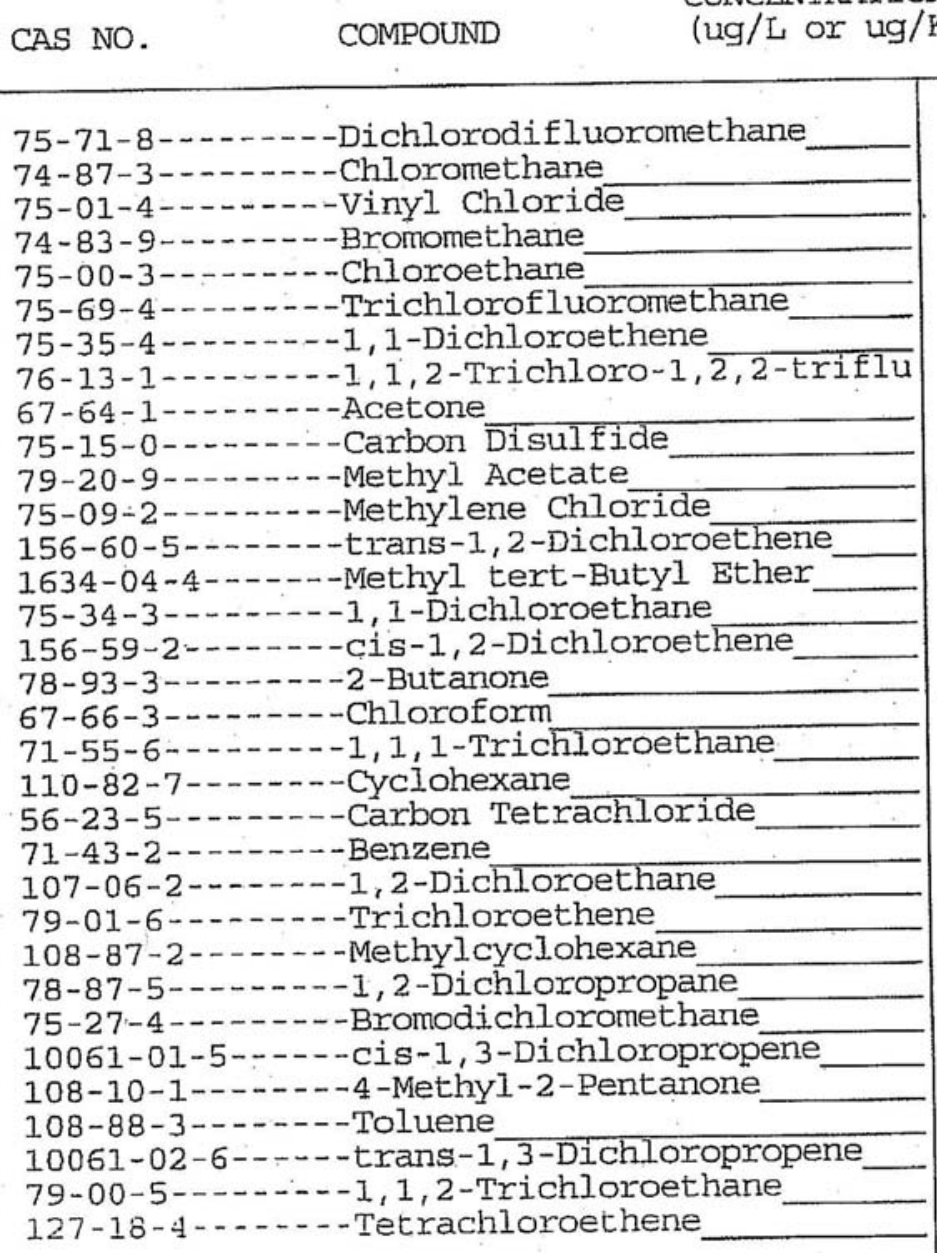


FORM 1

VOLATILE ORGANICS ANALYSIS DATA SHEET

Lab Name: ENVIROSYSTEMS, INC.

Lab Code: ENVSYS Case No.:

Matrix: (soil/water) WATER

Sample wt/vol:

$5.000(\mathrm{~g} / \mathrm{mL}) \mathrm{ML}$

Level: (low/med) LOW

\% Moisture: not dec.

GC Column: RTX-624. ID: 0.18 (mm)

Soil Extract Volume: (UL)
Contract: N/A

SAS NO.: N/A
ARGONNE SAMPLE NO.

CNQCTB-W-26014
Lab Sample ID: 0080308-04

Lab File ID: F000446

Date Received: 03/14/08

Date Analyzed: 03/14/08

Dilution Factor: 1.0

Soil Aliquot Volume: (UL)

CAS NO

COMPOUND CONCENTRATION UNITS: (ug/L or ug/Kg) UG/L

$5.0 \mathrm{U}$

$5.0 \mathrm{U}$

$5.0 \mathrm{U}$

$5.0 \mathrm{U}$

$5.0 \mathrm{U}$

$5.0 \mathrm{U}$

$5.0 \mathrm{U}$

$5.0 \mathrm{U}$

$5.0 \mathrm{U}$

$5.0 \mathrm{U}$

$5.0 \mathrm{U}$

$5.0 \mathrm{U}$

$5.0 \mathrm{U}$

$5.0 \mathrm{U}$

$5.0 \mathrm{U}$

$10 \mathrm{U}$

$5.0 \mathrm{U}$

$10 \mathrm{U}$

$10 \mathrm{U}$

$10 \mathrm{U}$

$10 \mathrm{U}$ 
FORM 1 VOLATILE ORGANICS ANALYSIS DATA SHEET

Lab Name: ENVIROSYSTEMS, INC. Lab Code: Envsys Case No.: Matrix: (soil/water) WATER Sample wt/vol: $5.000(\mathrm{~g} / \mathrm{mL}) \mathrm{ML}$

Level: (low/med) LOW

\% Moisture: not dec. GC Column: RTX-624 ID: 0.18 (mm) Soil Extract Volume: (uI)
Contract: $\mathrm{N} / \mathrm{A}$

SAS NO.: N/A
ARGONNE SAMPLE NO.

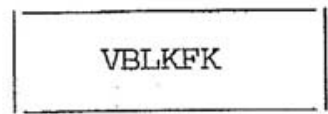

SDG NO.: NA

Lab Sample ID: 0C81403-BLKI

Lab File ID: F000443

Date Received:

Date Analyzed: 03/14/08

Dilution Factor: 1.0

Soil Aliquot Volume: (Uน)

CAS NO. COMPOUND (ug/L or $\mathrm{ug} / \mathrm{Kg}) \mathrm{UG} / \mathrm{L}$

Q

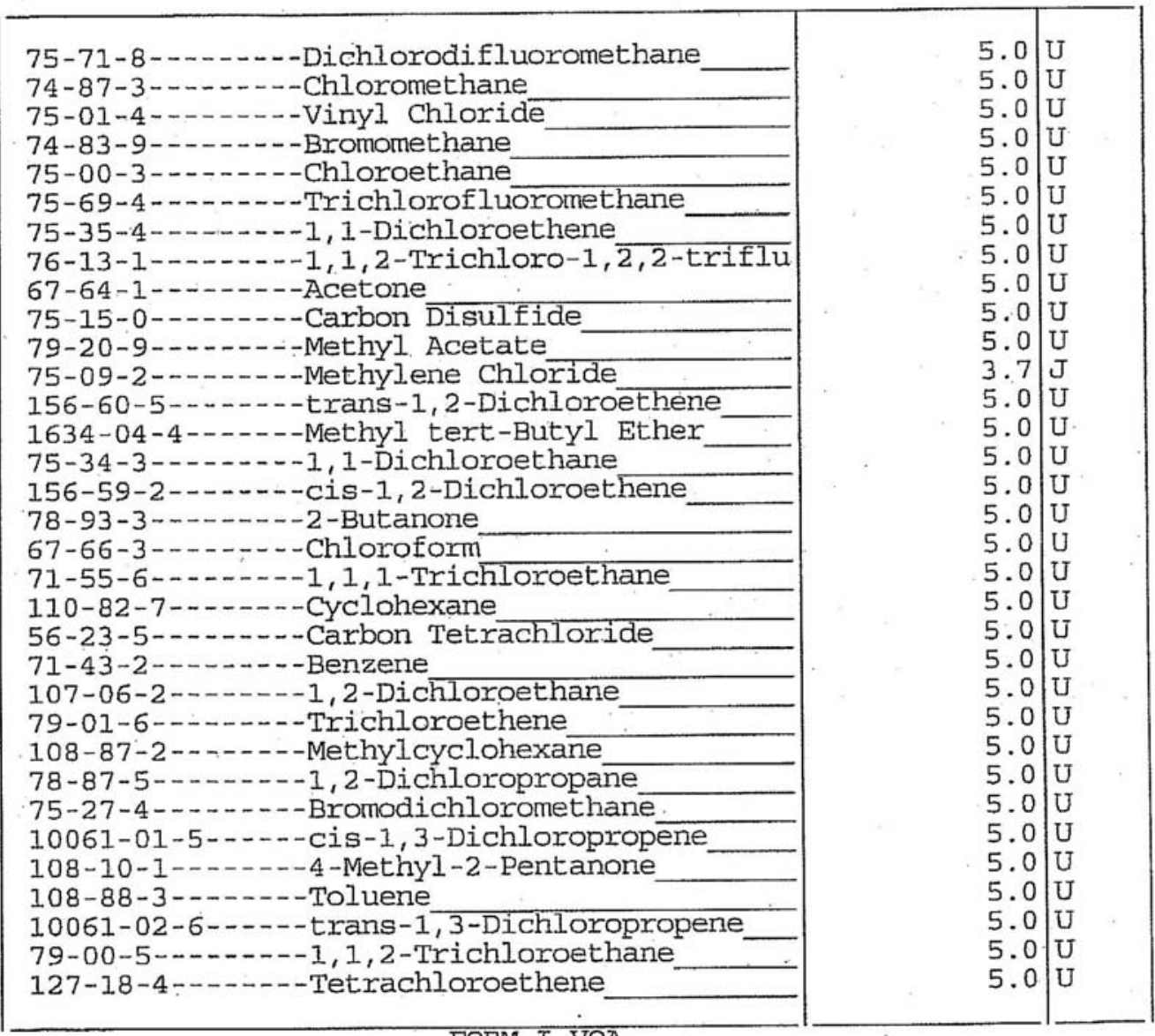

FORM I VOA 
FORM 1

VOIATILE ORGANICS ANALYSIS DATA SHEET

Lab Name: ENVIROSYSTEMS, INC.

Lab Code: ENVSYS Case No.:

Matrix: (soil/water) WATER

Sample wt/vol: $\quad 5.000(\mathrm{~g} / \mathrm{mL}) \mathrm{ML}$

Level: (low/med) LOW

\% Moisture: not dec.

GC Column: RTX-624 ID: 0.18 (mn)

Soil Extract Volume: (uा)
Contract: $\mathrm{N} / \mathrm{A}$

SAS NO.: N/A
ARGONNE SAMPLE NO.

\section{VBLKFK}

SDG No.: NA

Lab Sample ID: 0C81403-BLKI

Lab File ID: F000443

Date Received:

Date Analyzed: 03/14/08

Dilution Factor: 1.0

Soil Aliquot Volume: (uL)

CAS NO.

COMPOUND

CONCENTRATION UNITS :

(ug/L or $u g / K g$ ) UG/L . Q

$5.0 \mathrm{U}$

$5.0 \mathrm{U}$

$5.0 \mathrm{U}$

$5.0 \mathrm{U}$

$5.0 \mathrm{U}$

$5.0 \mathrm{U}$

$5.0 \mathrm{U}$

$5.0 \mathrm{U}$

$5.0 \mathrm{U}$

$5.0 \mathrm{U}$

$5.0 \mathrm{U}$

$5.0 \mathrm{U}$

$5.0 \mathrm{U}$

$5.0 \mathrm{U}$

$5.0 \mathrm{U}$

$10 \mathrm{U}$

$5.0 \mathrm{U}$

$10 \mathrm{U}$

$10 \mathrm{U}$

$10 \mathrm{U}$

$10 \mathrm{U}$ 


\section{ENVIROSYSTEMS, INC.}

9200 Rumsey Road - Suite B102 - Columbia, Maryland 21045-1934

Phone (410) 964-0330 - Fax (410) 740-9306

Email: info@envsystems.com - Webpage: www.envsystems.com/envsys

April 17, 2008

Jorge S. Alvarado, PH. D

Argonne National Laboratory

Environmental Research Division

Applied Geosciences and Environmental

Management Section

9700 South Cass Avenue, ER-203

Argonne, Illinois 60439

RE: Report \#080163

Dear Jorge,

Enclosed is the Analytical Data Package for the samples received on March 20, 2008 for volatile organics analysis by USEPA SW846 method 8260B/CLP SOW OLM04.3 protocols.

Please do not hesitate to call if you have any questions, comments, or require additional information.

Sincerely,

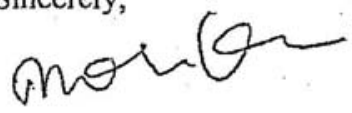

Mohan Khare Ph.D.

President/CEO

Enclosure (1)

$\mathrm{MK} / \mathrm{ncc}$

Envirosystems, lnc.

Report\#080163 


\section{SDG NARRATIVE VOLATMLE ORGANICS (VOC)}

Envirosystems, Inc.

Contract: N/A

Client: Argonne National Laboratory

Case: N/A

SDG: ARG032008

\section{SAMPLE RECIEPT}

Date received: 03-20-2008

Cooler Temperature: 2

\section{Sample Summary}

\begin{tabular}{|c|c|c|c|}
\hline Client ID & Laboratory I & Matrix & pH \\
\hline CNMW04-W-26024 & $0080313-01$ & WATER & 2 \\
\hline CNMW04-W-26026 & $0080313-02$ & WATER & 2 \\
\hline CNQCTB-W26035 & $0080313-03$ & WATER & 2 \\
\hline
\end{tabular}

\section{HOLDING TIMES}

3.

A. Sample Preparation: All holding times were met.

B. Sample Analysis: Sample analysis proceeded normally.

4. METHODS

5.

The samples were analyzed and reported by using method SW-846 $8260 \mathrm{~B}$ and USEPA CLP SOW OLM04.3 for target compound list.

\section{INSTRUMENT AND CHROMATOGRAPHIC CONDITIONS}

A Hewlett Packard 6890 gas chromatograph equipped with a Hewlett Packard 5975 MSD was used for sample analysis. The capillary column used was a Restek $20 \mathrm{~m}$ by $0.18 \mathrm{~mm}$ ID by $1.0 \mu \mathrm{m}$ film thickness (Restek Cat. \# RTX-624). The trap used with the sample concentrator is an O1 Analytical Trap \#10, 30cm packed with Tenax/silica gel/cms (PN\#228122).

\section{PREPARATION}

The submitted samples were prepared and analyzed using method SW-846 8260B.

\section{ANALYSIS}

A. Calibration:

\section{l. Initial calibration}

All acceptance criteria as stipulated by SW-846 $8260 \mathrm{~b}$ were met for all SPCC's and $\mathrm{CCC}^{\dagger}$ s. All target compounds met the required percent RSD.

II. Blanks:

All acceptance criteria were met.

II. Surrogates:

All acceptance criteria were met.

B. Spikes:

I. Laboratory Control Spikes (LCS)

II. LCS sample was analyzed which met all the QC criteria. 


\section{SDG NARRATIVE VOLATILE ORGANICS (VOC)}

\section{Matrix Spike/Matrix Spike Duplicate (MS/MSD)}

MS/MSD were performed for sample CNMW04-W-26024. All QC criteria were met.

\section{Internal Standards:}

All acceptance criteria were met.

\section{Samples}

Sample analysis proceeded normally.

I certify that this Sample Data Package is in compliance with the terms and conditions of the contract, both technically and for completeness, for other than the conditions detailed above. Release of the data contained in the hard copy Sample Data Package and in the Electronic Data Deliverables has been authorized by the laboratory manager or the manager's designee, as verified by the following signatures.
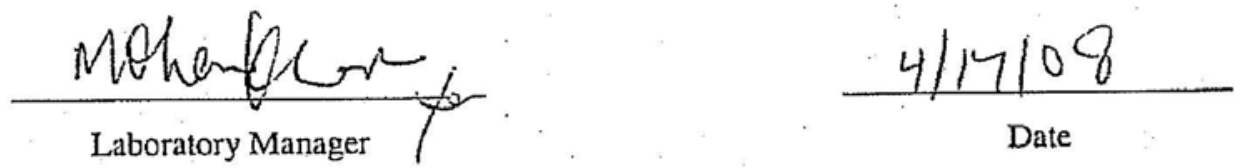
Version 00, 04/24/08

\section{Chain Of Custody}




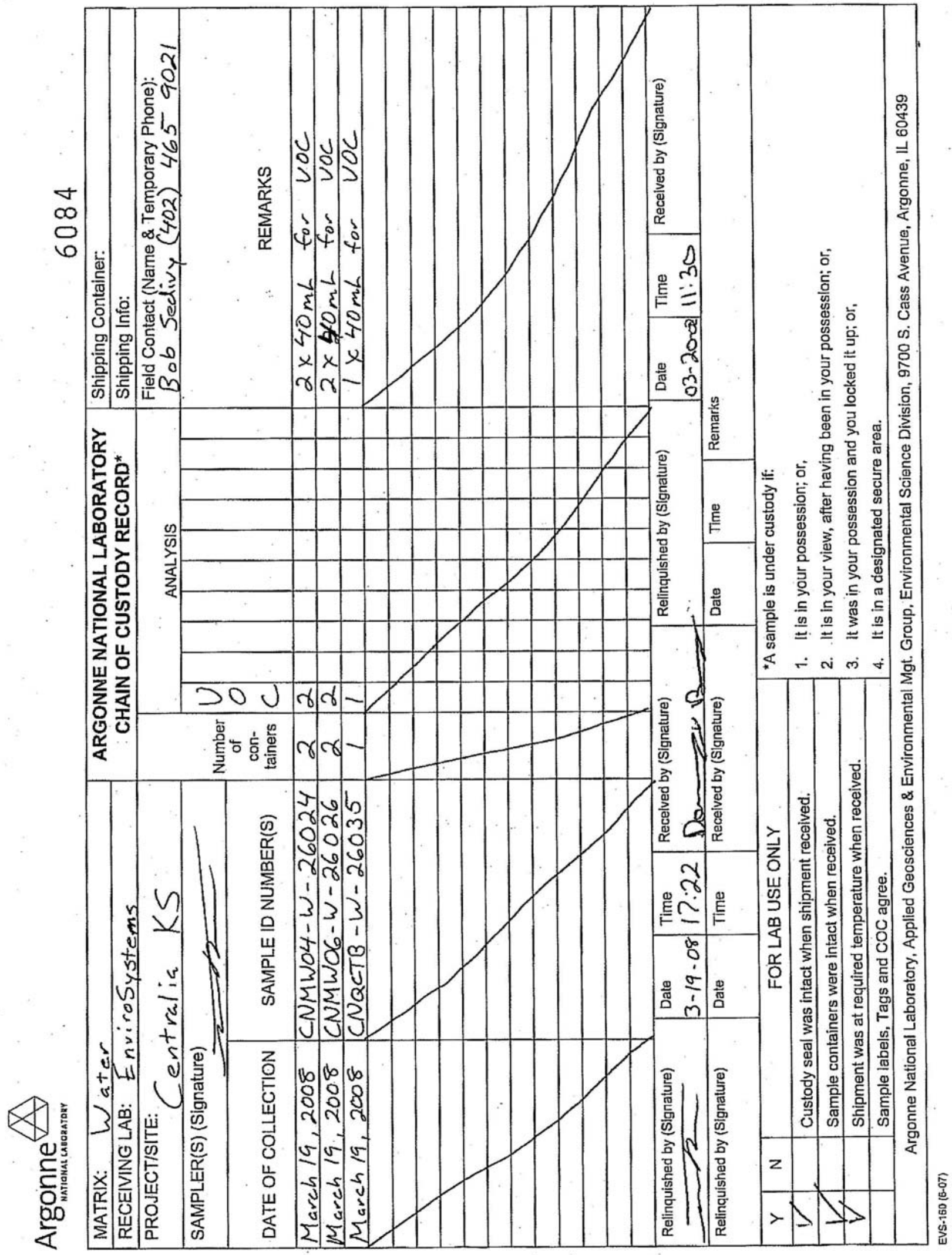


FORM 1

VOLATILE ORGANICS ANALYSIS DATA SHEET

Lab Name: ENVIROSYSTEMS, INC.

Lab Code: ENVSYS Case No.:

Matrix: (soil/water) WATER

Sample wt/vol:

$5.000(\mathrm{~g} / \mathrm{mL}) \mathrm{ML}$

Level: (low/med) LOW

\% Moisture: not dec.

GC Column: RTX-624 ID: 0.18 (mm)

Soil Extract Volume:

(ut)
Contract: N/A

SAS NO.: N/A
ARGONNE SAMPLE NO.

CNMW04-W-26024

Lab Sample ID: 0080313-01

Lab File ID: F000458

Date Received: 03/20/08

Date Analyzed: 03/21/08

Dilution Factor: 1.0

Soil Aliquot Volume:

(UL)

CONCENTRATION UNITS:

CAS NO.

COMPOUND

(ug/L or ug/Kg) UG/L

Q

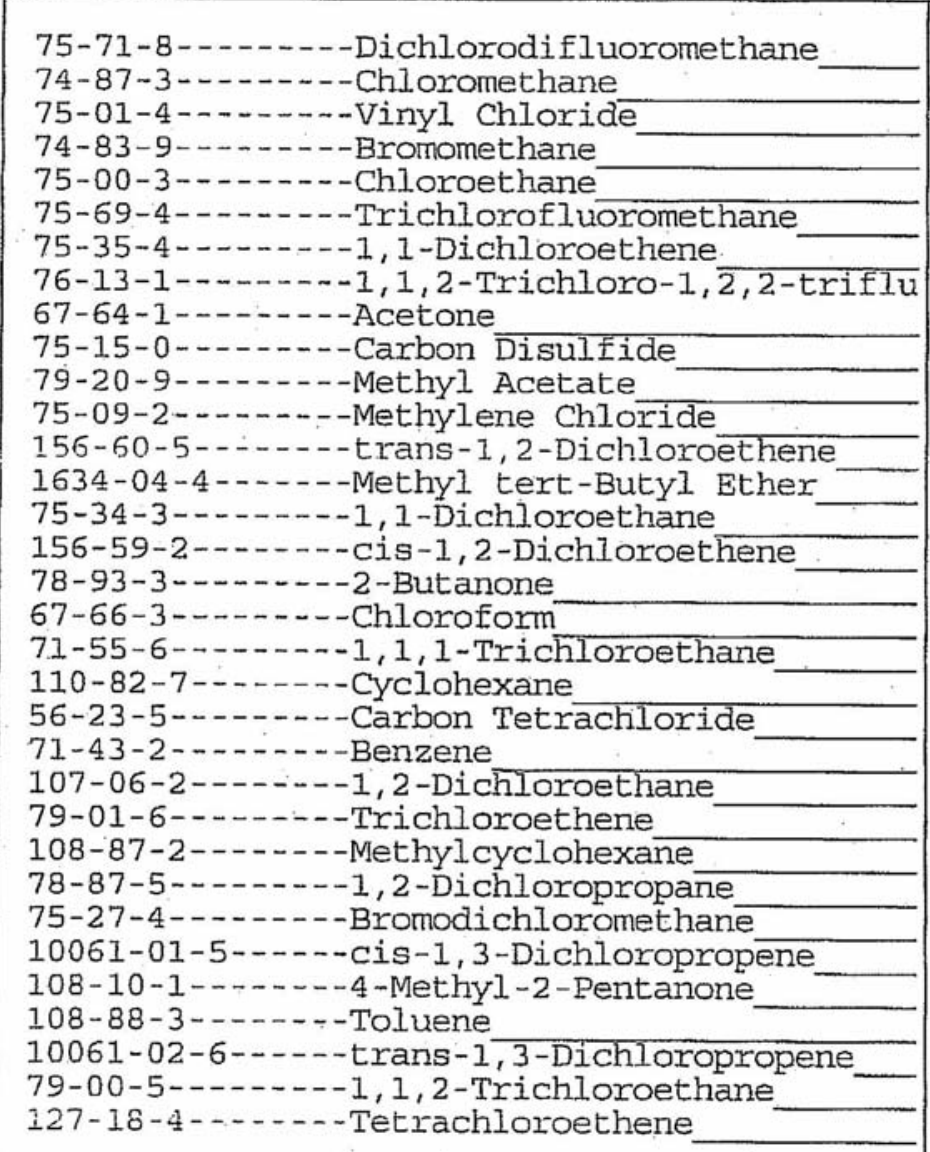

$5.0 \mathrm{U}$

$5.0 \mathrm{U}$

$5.0 \mathrm{U}$

$5.0 \mathrm{U}$

$5.0 \mathrm{U}$

$5.0 \mathrm{U}$

$5.0 \mathrm{U}$

$5.0 \mathrm{U}$

$5.0 \mathrm{U}$

5:0 U

$5.0 \mathrm{U}$

6.8

$5.0 \mathrm{U}$

$5.0 \mathrm{U}$

$5.0 \mathrm{U}$

$5.0 \mathrm{U}$

$5.0 \mathrm{U}$

$5.0 \mathrm{U}$

$5.0 \mathrm{U}$

$5.0 \mathrm{U}$

$5.0 \mathrm{U}$

$5.0 \mathrm{U}$

$5.0 \mathrm{U}$

$5.0 \mathrm{U}$

$5.0 \mathrm{U}$

$5.0 \mathrm{U}$

$5.0 \mathrm{U}$

$5.0 \mathrm{U}$

$5.0 \mathrm{U}$

$1.2 \mathrm{~J}$

$5.0 \mathrm{U}$

$5.0 \mathrm{U}$

$5.0 \mathrm{U}$ 
FORM 1

\section{VOLATILE ORGANICS ANALYSIS DATA SHEET}

Lab Name: ENVIROSYSTEMS, INC.

Lab Code: ENVSYS Case No.:

Matrix: (soil/water) WATER

Sample wt/vol: $\quad 5.000(\mathrm{~g} / \mathrm{mL}) \mathrm{ML}$

Level: (low/med) LOW

\% Moisture: not dec.

GC Column: RTX-624 ID: 0.18 (mm)

Soil Extract Volume: (uL)
Contract: N/A

SAS NO.: N/A
ARGONNE SAMPLE NO.

CNNW04-W-26024

Lab Sample ID: 0080313-01

Lab File ID: F000458

Date Received: 03/20/08

Date Analyzed: 03/21/08

Dilution Factor: 1.0

Soil Aliquot Volume: (u山)

CONCENTRATION UNITS:

CAS NO.

COMPOUND

(ug/L or ug/Kg) UG/I

Q

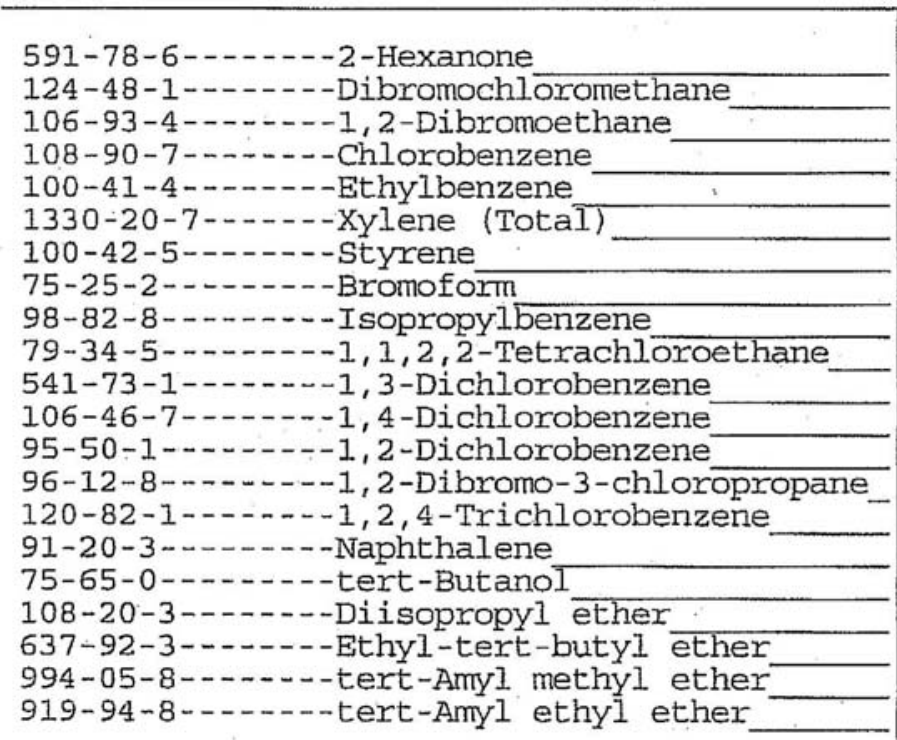

$5.0 \mathrm{U}$

$5.0 \mathrm{U}$

$5.0 \mathrm{U}$

$5.0 \mathrm{U}$

$5.0 \mathrm{U}$

$5.0 \mathrm{U}$

$5.0 \mathrm{U}$

$5.0 \mathrm{U}$

5. 0 U

$5.0 \mathrm{U}$

$5.0 \mathrm{U}$

$5.0 \mathrm{U}$

$5.0 \mathrm{U}$

$5.0 \mathrm{U}$

$5.0 \mathrm{U}$

$10 \mathrm{U}$

$5.0 \mathrm{U}$

$10 \mathrm{U}$

$10 \mathrm{U}$

$10 \mathrm{U}$

919-94-8--.--tert-Amyl ethyl ether 
FORM 1 VOLATILE ORGANICS ANALYSIS DATA SHEET

Lab Name: ENVIROSYSTEMS, INC. Lab Code: ENVSYS Case No.: Matrix: (soil/water) WATER Sample wt/vol: $\quad 5.000(\mathrm{~g} / \mathrm{m} \omega) \mathrm{ML}$ Level: (low/med) LOW \% Moisture: not dec. GC Column: RTX-624 ID: 0.18 (mm) Soil Extract Volume: (uL)
Contract: $\mathrm{N} / \mathrm{A}$

SAS NO.: N/A
ARGONNE SAMPLE NO.

CNIMW06-W-26026
SDG No. : NA
Lab Sample ID: 0080313-02

Lab File ID: F000461

Date Received: 03/20/08

Date Analyzed: 03/21/08

Dilution Factor: 1.0

Soil Aliquot Volume: (uL)

CAS NO.

COMPOUND

CONCENTRATION UNITS: (ug/L or $\mathrm{ug} / \mathrm{Kg}$ ) UG/L

Q

\begin{tabular}{|c|}
\hline 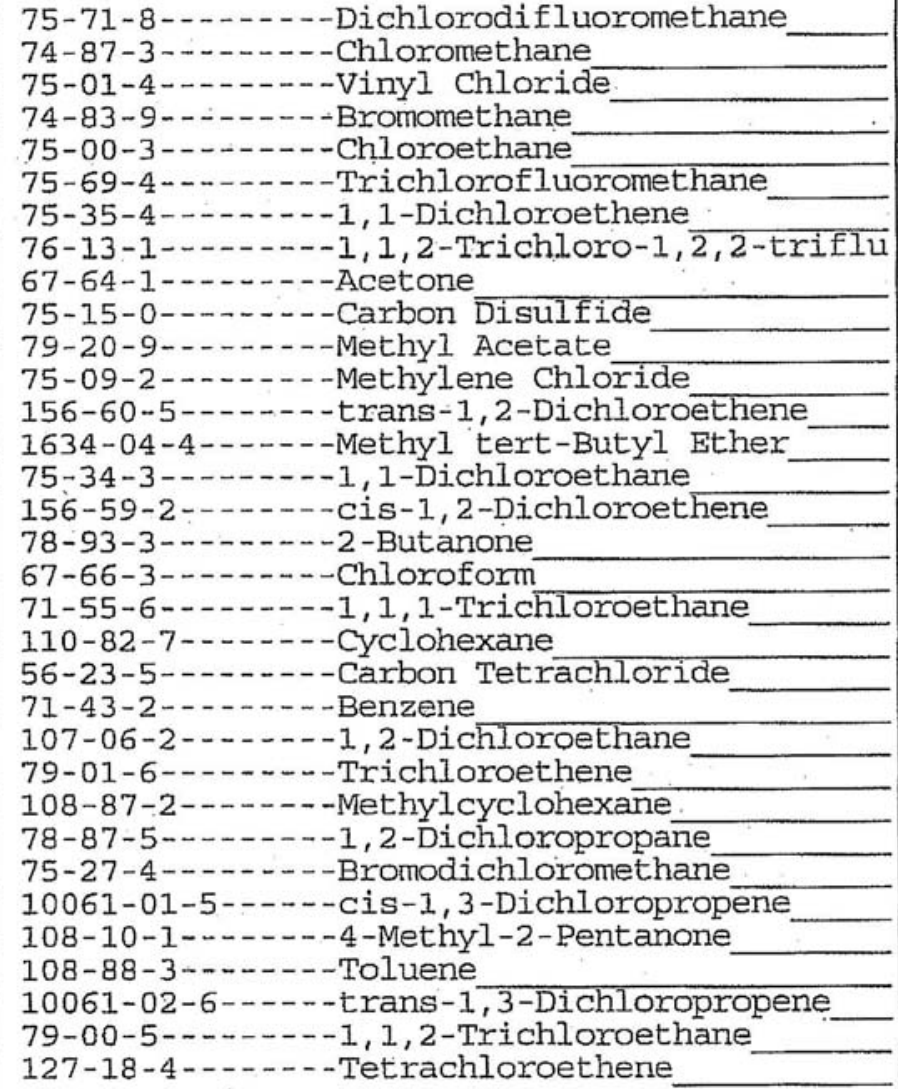 \\
\hline
\end{tabular}

$5.0 \mathrm{U}$

$5.0 \mathrm{U}$

$5.0 \mathrm{U}$

$5.0 \mathrm{U}$

$5.0 \mathrm{U}$

$5.0 \mathrm{U}$

$5.0 \mathrm{U}$

$5.0 \mathrm{U}$

$5.0 \mathrm{U}$

$5.0 \mathrm{U}$

$5.0 \mathrm{U}$

7.0

$5.0 \mathrm{U}$

$5.0 \mathrm{U}$

$5.0 \mathrm{U}$

$5.0 \mathrm{U}$

$5.0 \mathrm{U}$

$5.0 \mathrm{U}$

$5.0 \mathrm{U}$

$5.0 \mathrm{U}$

$5.0 \mathrm{U}$

$5.0 \mathrm{U}$

$5.0 \mathrm{U}$

$5.0 \mathrm{U}$

$5.0 \mathrm{U}$

$5.0 \mathrm{U}$

$5.0 \mathrm{U}$

$5.0 \mathrm{U}$

$5.0 \mathrm{U}$

$1.4 \mathrm{~J}$

$5.0 \mathrm{U}$

$5.0 \mathrm{U}$

$5.0 \mathrm{U}$ 
ARGONNE SAMPLE NO.

\section{VOLATILE ORGANICS ANALYSIS DATA SHEET}

Lab Name: ENVIROSYSTEMS, INC.

Contract: N/A

CNMW06-W-26026
Lab Code: ENVSYS Case No.:

Matrix: (soil/water) WATER.

Sample wt/vol: $\quad 5.000(\mathrm{~g} / \mathrm{mL})$ ML

Level: (low/med) LOW

음 Moisture: not dec.

GC Column: RTX-624 ID: 0.18 (mm)

Soil Extract Volume:

(uL)
SAS NO. : N/A

SDG NO.: NA

Lab Sample ID: 0080313-02

Lab File ID: F000461

Date Received: 03/20/08

Date Analyzed: 03/21/08

Dilution Factor: 1.0

Soil Aliquot Volume: (uL)

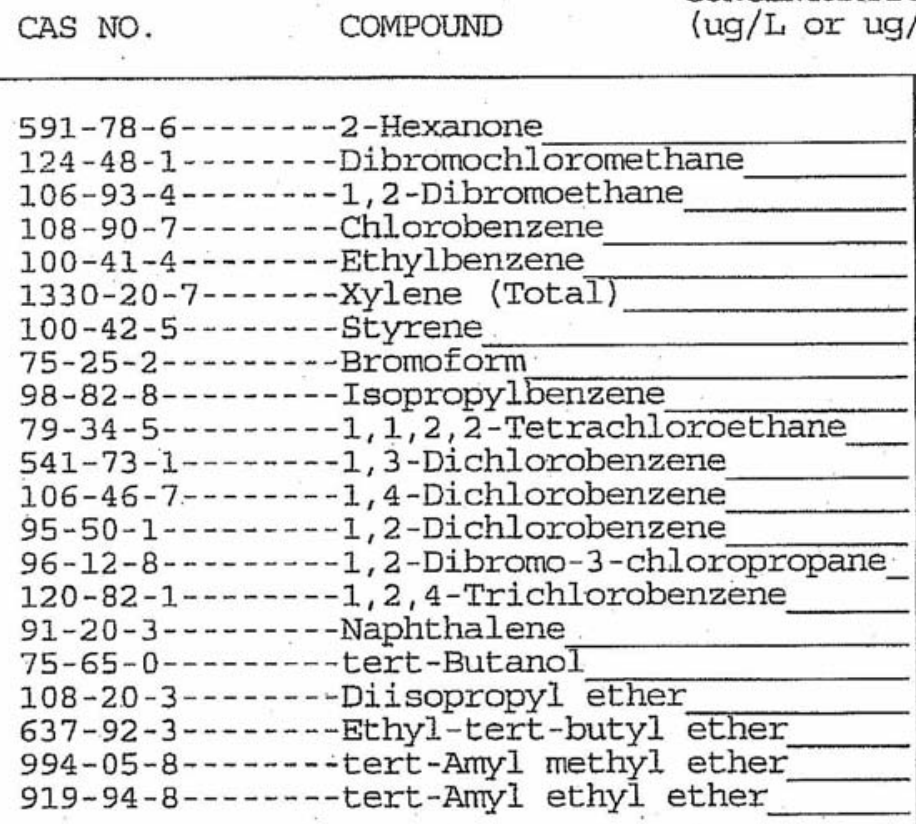

CONCENTRATION UNITS:

(ug/L or ug/Kg) UG/L

Q

\begin{tabular}{|r|r|}
5.0 & $\mathrm{U}$ \\
5.0 & $\mathrm{U}$ \\
5.0 & $\mathrm{U}$ \\
5.0 & $\mathrm{U}$ \\
5.0 & $\mathrm{U}$ \\
5.0 & $\mathrm{U}$ \\
5.0 & $\mathrm{U}$ \\
5.0 & $\mathrm{U}$ \\
5.0 & $\mathrm{U}$ \\
5.0 & $\mathrm{U}$ \\
5.0 & $\mathrm{U}$ \\
5.0 & $\mathrm{U}$ \\
5.0 & $\mathrm{U}$ \\
5.0 & $\mathrm{U}$ \\
5.0 & $\mathrm{U}$ \\
10 & $\mathrm{U}$ \\
5.0 & $\mathrm{U}$ \\
10 & $\mathrm{U}$ \\
10 & $\mathrm{U}$ \\
1.0 & $\mathrm{U}$ \\
10 & $\mathrm{U}$ \\
\hline
\end{tabular}

FORM I VOA 
FORM 1

VOLATILE ORGANICS ANALYSIS DATA SHEET

Lab Name: ENVIROSYSTEMS, INC.

Iuab Code: ENVSYS Case No.:

Matrix: (soil/water) WATER

Sample wt/vol:

$5.000(\mathrm{~g} / \mathrm{mL}) \mathrm{ML}$

Level: (low/med) LOW

\% Moisture: not dec.

GC Column: RTX-624 ID: 0.18 (mm)

Soil Extract Volume: (UL)
Contract: $\mathrm{N} / \mathrm{A}$

SAS NO.: N/A
ARGONNE SAMPLE NO.

CNQCTB-W-26035
Lab Sample ID: 0080313-03

Lab File ID: F000462

Date Received: 03/20/08

Date Analyzed: 03/21/08

Dilution Factor: 1.0

Soil Aliquot Volume: (uL)

CAS NO.

COMPOUND

CONCENTRATION UNITS :

(ug/L or $u g / \mathrm{Kg}$ ) UG/L

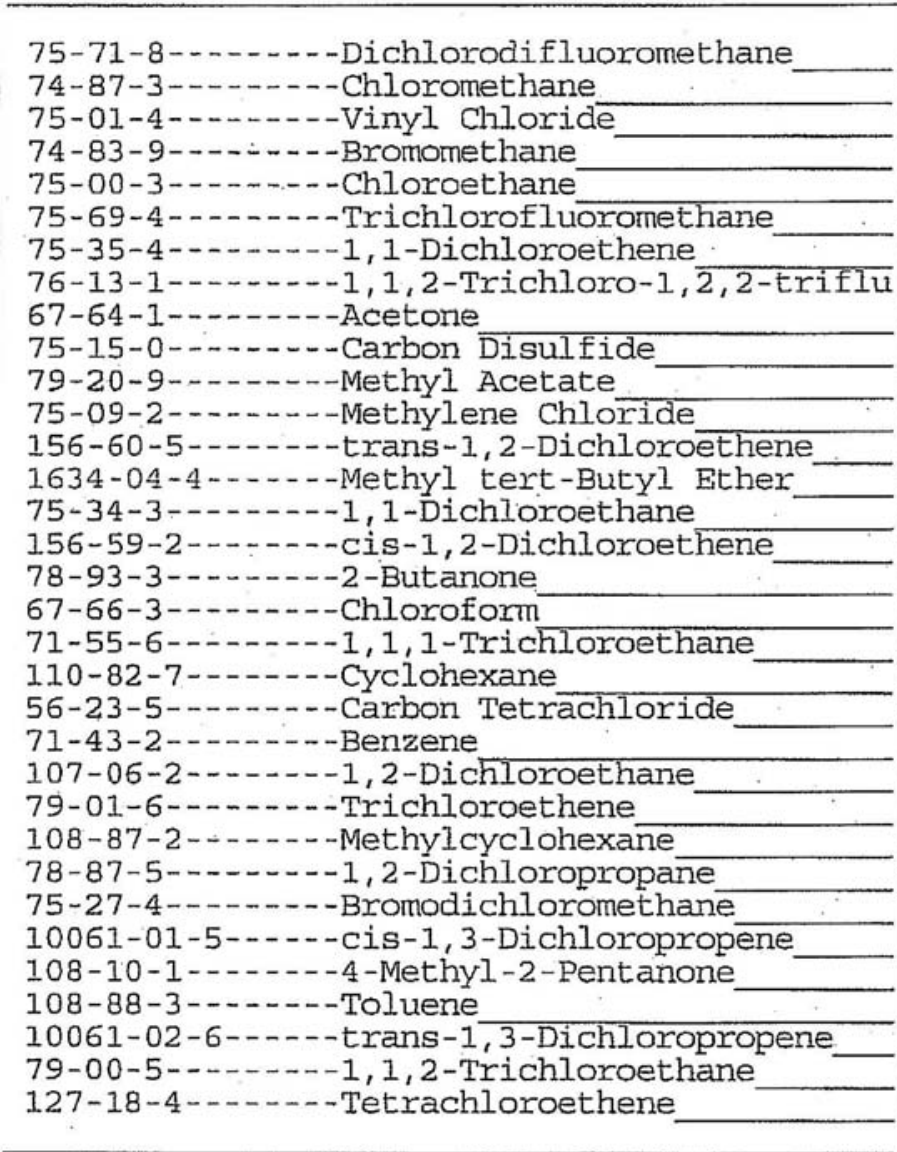

$5.0 \mathrm{U}$

$5.0 \mathrm{U}$

$5.0 \mathrm{U}$

$5.0 \mathrm{U}$

$5.0 \mathrm{U}$

$5.0 \mathrm{U}$

$5.0 \mathrm{U}$

$5.0 \mathrm{U}$

$5.0 \mathrm{U}$

$5.0 \mathrm{U}$

$5.0 \mathrm{U}$

6.6

$5.0 \mathrm{U}$

$5.0 \mathrm{U}$

$5.0 \mathrm{U}$

$5.0 \mathrm{U}$

$5.0 \mathrm{U}$

$5.0 \mathrm{U}$

$5.0 \mathrm{U}$

$5.0 \mathrm{U}$

$5.0 \mathrm{U}$

$5.0 \mathrm{U}$

$5.0 \mathrm{U}$

$5.0 \mathrm{U}$

$5.0 \mathrm{U}$

$5.0 \mathrm{U}$

$5.0 \mathrm{U}$

$5.0 \mathrm{U}$

$5.0 \mathrm{U}$

$5.0 \mathrm{U}$

$5.0 \mathrm{U}$

$5.0 \mathrm{U}$

$5.0 \mathrm{U}$

Q 
FORM 1

VOLATILE ORGANICS ANALYSIS DATA SHEET
ARGONNE SAMPLE NO.

CNQCTB-W-26035
Lab Name: ENVIROSYSTEMS, INC.

Lab Code: Envsys Case No. :

Matrix: (soil/water) WATER

Sample wt/vol: $\quad 5.000(\mathrm{~g} / \mathrm{mL}) \mathrm{ML}$

Level: (low/med) LOW

․․․ Moisture: not dec.

GC Column: RTX-624 ID: 0.18 (mm)

Soil Extract Volume:
Contract: N/A

SAS NO.: N/A
SDG No.: NA

Lab Sample ID: 0080313-03

Lab File ID: F000462

Date Received: 03/20/08

Date Analyzed: 03/21/08

Dilution Factor: 1.0 (uL) CONCENTRATION UNITS:

CAS NO. COMPOUND (ug/L or ug/Kg) UG/L

Q

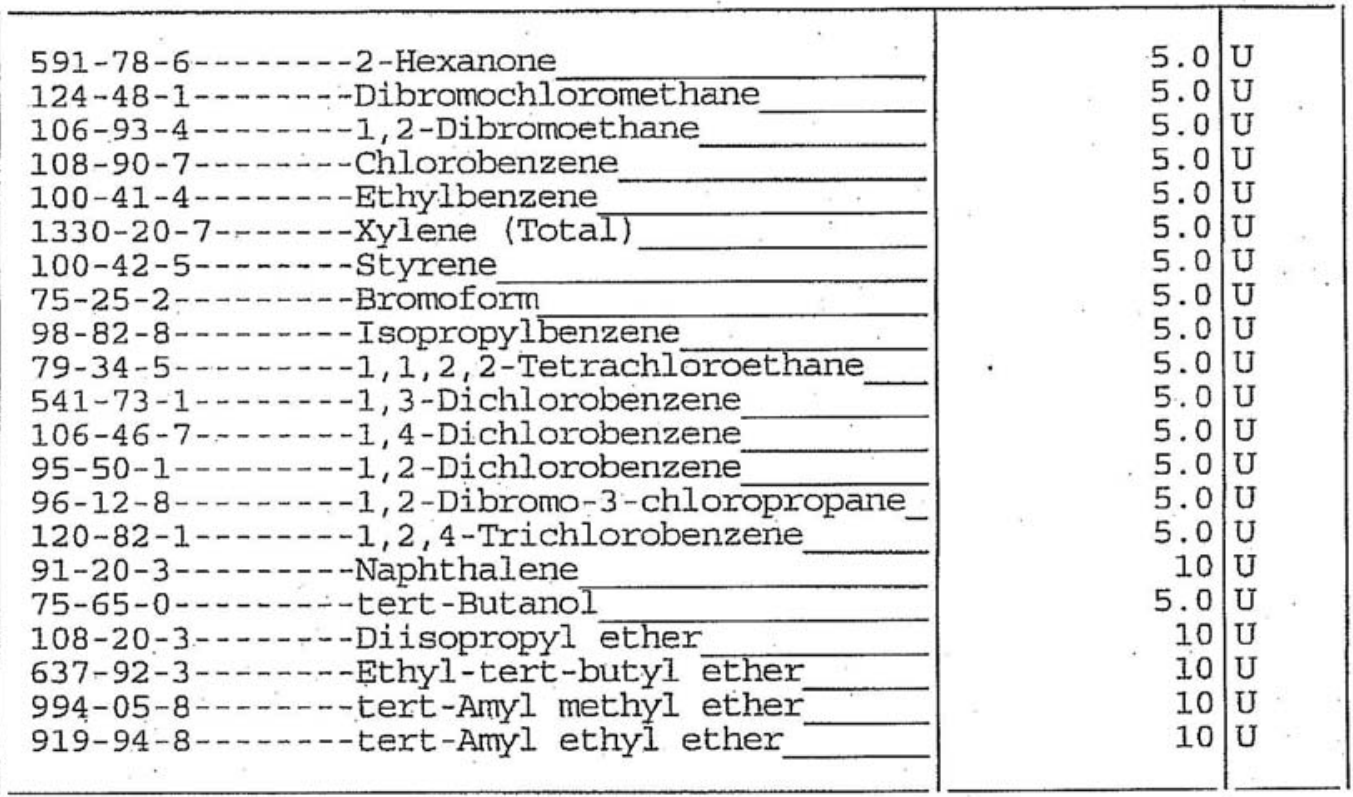


FORM 1

VOLATILE ORGANICS ANALYSIS DATA SHEET

Lab Name: ENVIROSYSTEMS, INC.

Lab Code: ENVSYS Case No. :

Matrix: (soil/water) WATER

sample wt/vol:

$5.000(\mathrm{~g} / \mathrm{mL}) \mathrm{ML}$

Level: (low/med) LOW

\% Moisture: not dec.

GC Column: RTX-624 ID: 0.18 (mm)

Soil Extract Volume:

(uT)
Contract: N/A

SAS NO.: N/A
ARGONNE SAMPLE NO.

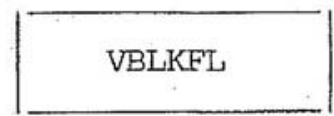

SDG No.: NA

Lab Sample ID: 0000796-BLKI

Lab File ID: F000455

Date Received: 03/20/08

Date Analyzed: 03/20/08

Dilution Factor: 1.0

Soil Aliquot Volume:

(uL)

CAS NO.

COMPOUND

CONCENTRATION UNITS:

(ug/L or ug/Kg) UG/L

Q

\begin{tabular}{|c|}
\hline 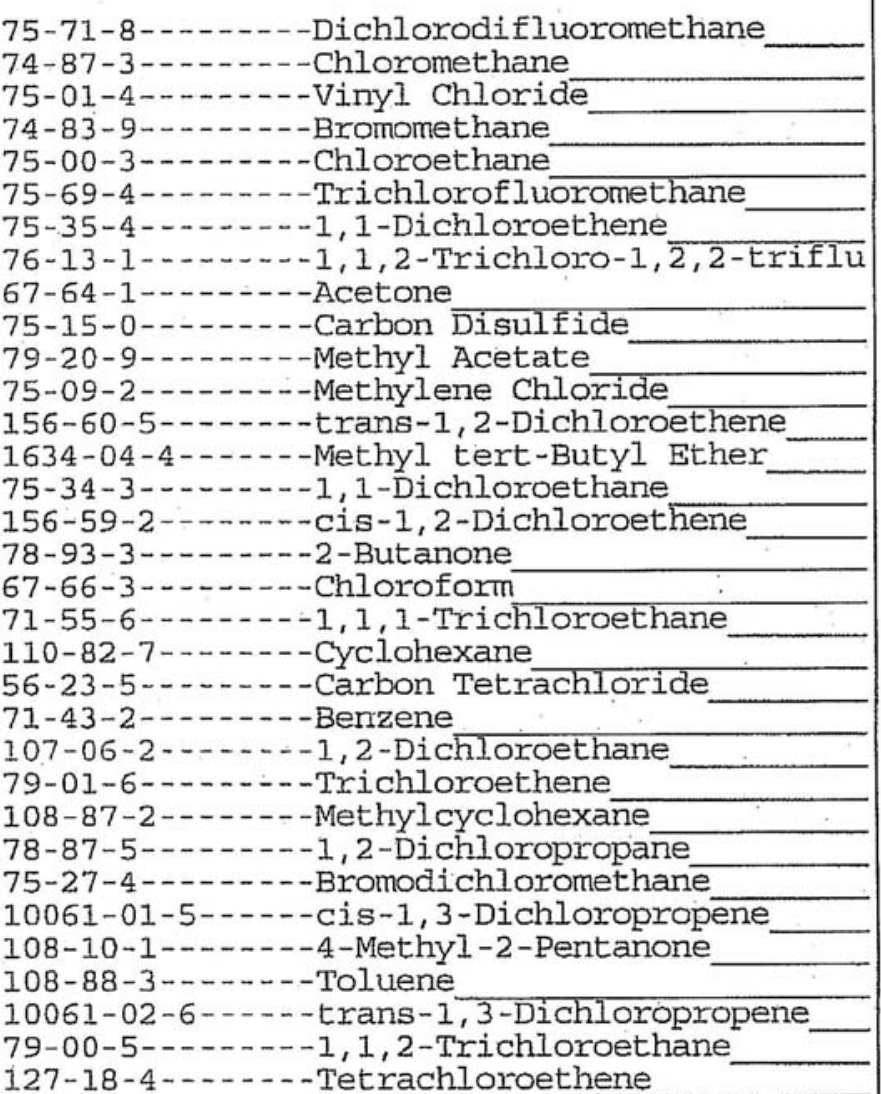 \\
\hline
\end{tabular}

$5.0 \mathrm{U}$

$5.0 \mathrm{U}$

$5.0 \mathrm{U}$

$5.0 \mathrm{U}$

$5.0 \mathrm{U}$

$5.0 \mathrm{U}$

$5.0 \mathrm{U}$

$5.0 \mathrm{U}$

$5.0 \mathrm{U}$

$5.0 \mathrm{U}$

$5.0 \mathrm{U}$

5.5

$5.0 \mathrm{U}$

$5.0 \mathrm{U}$

$5.0 \mathrm{U}$

$5.0 \mathrm{U}$

$5.0 \mathrm{U}$

5.0. U

$5.0 \mathrm{U}$

$5.0 \mathrm{U}$

$5.0 \mathrm{U}$

$5.0 \mathrm{U}$

$5.0 \mathrm{U}$

$5.0 \mathrm{U}$

$5.0 \mathrm{U}$

$5.0 \mathrm{U}$

$5.0 \mathrm{U}$

$5.0 \mathrm{U}$

$5.0 \mathrm{U}$

$5.0 \mathrm{U}$

$5.0 \mathrm{U}$

$5.0 \mathrm{U}$

$5.0 \mathrm{U}$

FORM I VOA 
FORM 1

VOLATILE ORGANICS ANALYSIS DATA SHEET

Lab Name: ENVIROSYSTEMS, INC.

Lab Code: ENVSYS Case No.:

Matrix: (soil/water) WATER

Sample wt/vol: $\quad 5.000(\mathrm{~g} / \mathrm{mL}) \mathrm{ML}$

Level: (low/med) LOW

: Moisture: not dec.

GC Column: RTX-624 ID: 0.18 (mm)

Soil Extract Volume:

(uI)
Contract: N/A

SAS NO.: N/A
ARGONNE SAMPLE NO.

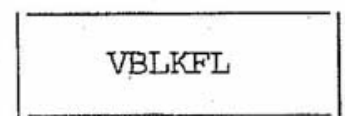

SDG No.: NA

Lab Sample ID: 0000796-BLKI

Lab File ID: F000455

Date Received: 03/20/08

Date Analyzed: 03/20/08

Dilution Factor: 1.0

Soil Aliquot Volume: (UI)

CAS NO.

COMPOUND

CONCENTRATION UNITS:

(ug/L or ug/Kg) UG/L

$Q$

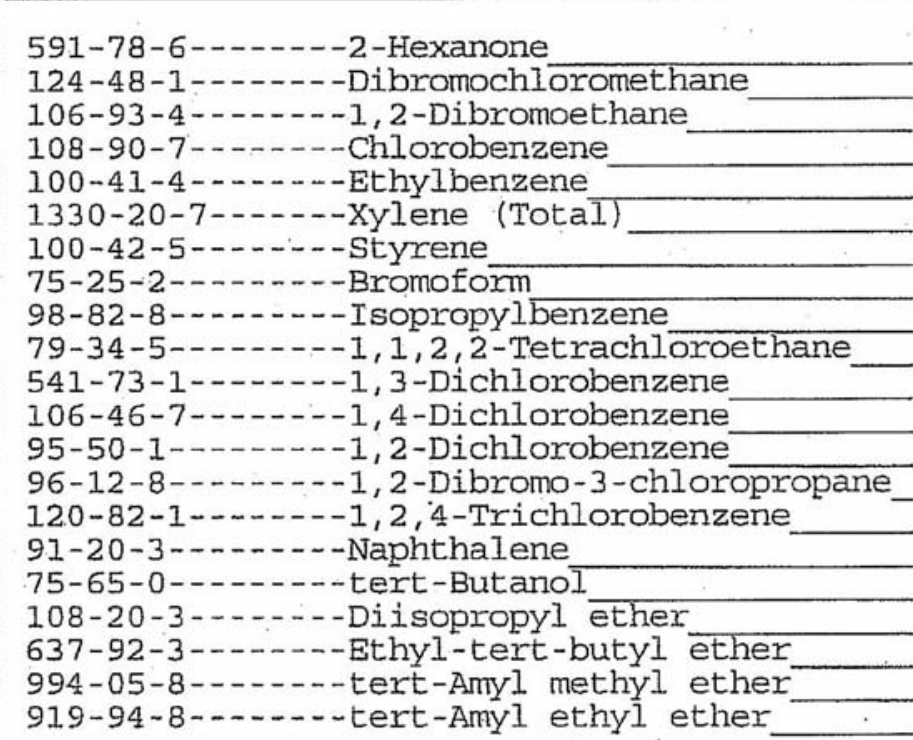

$5.0 \mathrm{U}$

$5.0 \mathrm{U}$

$5.0 \mathrm{U}$

$5.0 \mathrm{U}$

$5.0 \mathrm{U}$

$5.0 \mathrm{U}$

$5.0 \mathrm{U}$

$5.0 \mathrm{U}$

$5.0 \mathrm{U}$

$5.0 \mathrm{U}$

$5.0 \mathrm{U}$

$5.0 \mathrm{U}$

$5.0 \mathrm{U}$

$5.0 \mathrm{U}$

$5.0 \mathrm{U}$

$10 \mathrm{U}$

$5.0 \mathrm{U}$

$10 \mathrm{U}$

$10 \mathrm{U}$

$10 \mathrm{U}$

919-94 8 ......-tert-Amyl ethyl ether

$10 \mathrm{U}$ 
Argonne

Environmental Science Division

Argonne National Laboratory

9700 South Cass Avenue, Bldg. 203

Argonne, IL 60439-4843

www.anl.gov

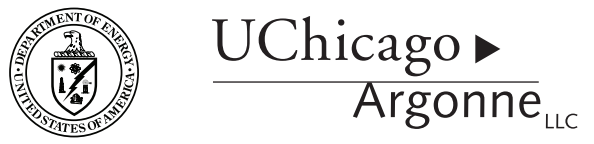

A U.S. Department of Energy laboratory

managed by UChicago Argonne, LLC 